\title{
FUNGIBLE AND COMPATIBLE BIOFUELS: LITERATURE SEARCH, SUMMARY, AND RECOMMENDATIONS
}

September 30, 2010

\author{
Prepared by \\ Bruce Bunting \\ Mike Bunce \\ Teresa Barone \\ John Storey
}

Oak Ridge National Laboratory Fuels, Engines, and Emissions Research Center

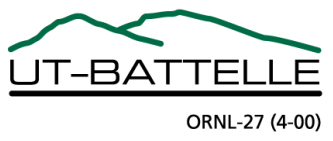


This report was prepared as an account of work sponsored by an agency of the United States Government. Neither the United States Government nor any agency thereof, nor any of their employees, makes any warranty, express or implied, or assumes any legal liability or responsibility for the accuracy, completeness, or usefulness of any information, apparatus, product, or process disclosed, or represents that its use would not infringe privately owned rights. Reference herein to any specific commercial product, process, or service by trade name, trademark, manufacturer, or otherwise, does not necessarily constitute or imply its endorsement, recommendation, or favoring by the United States Government or any agency thereof. The views and opinions of authors expressed herein do not necessarily state or reflect those of the United States Government or any agency thereof. 
Fuels, Engines, and Emissions Research Center

FUNGIBLE AND COMPATIBLE BIOFUELS:

LITERATURE SEARCH, SUMMARY, AND RECOMMENDATIONS

\author{
Bruce Bunting \\ Mike Bunce \\ Teresa Barone \\ John Storey
}

Date Published: September 30, 2010

Prepared by

OAK RIDGE NATIONAL LABORATORY

Oak Ridge, Tennessee 37831-6283

managed by

UT-BATTELLE, LLC

for the

U.S. DEPARTMENT OF ENERGY

under contract DE-AC05-00OR22725 



\section{CONTENTS}

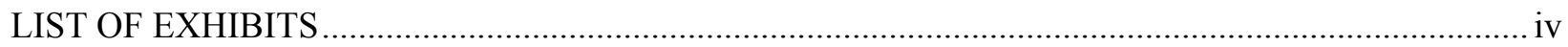

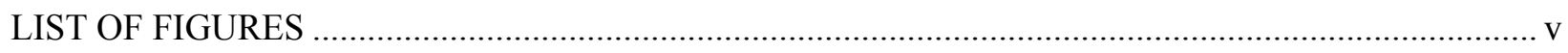

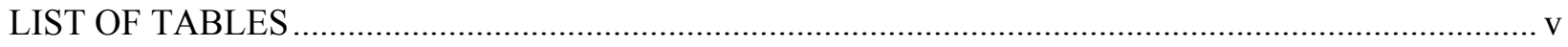

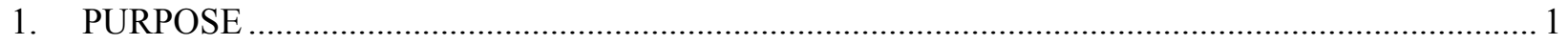

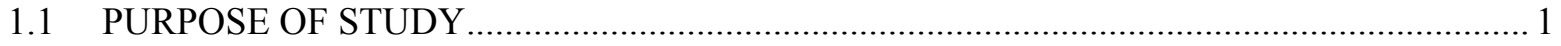

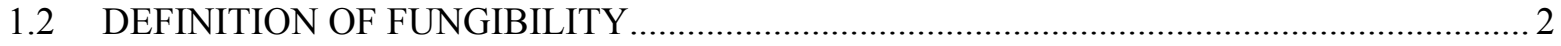

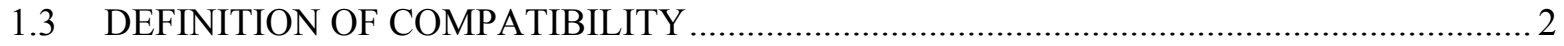

2. DESCRIPTION OF FUEL MANUFACTURING AND DISTRIBUTION IN THE

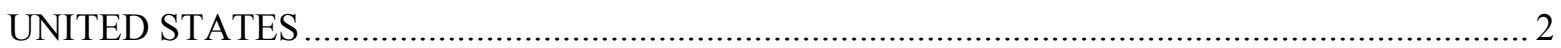

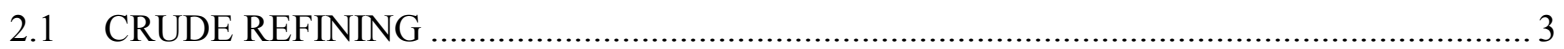

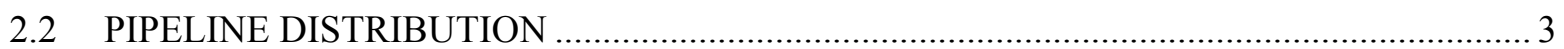

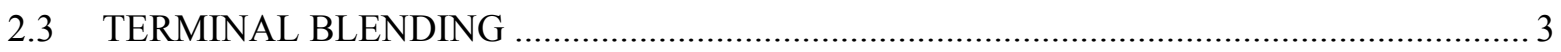

2.4 EXAMPLE PIPELINE DISTRIBUTION MAP ...................................................... 5

3. INCORPORATING BIOFUELS INTO THE CURRENT DISTRIBUTION SYSTEM.................... 6

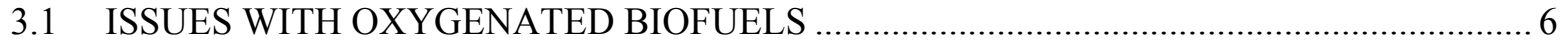

3.2 CURRENT PRACTICES AND PROPOSED SOLUTIONS …...................................... 6

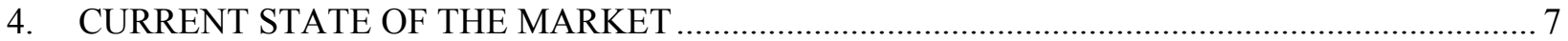

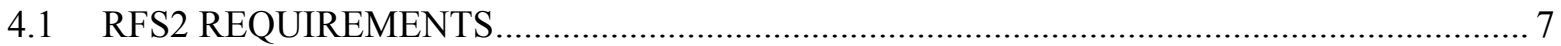

4.2 CURRENT PRODUCTION OF ETHANOL AND FAME.................................................. 9

4.3 HOW THE CURRENT MARKET DEALS WITH COMPATIBILITY AND

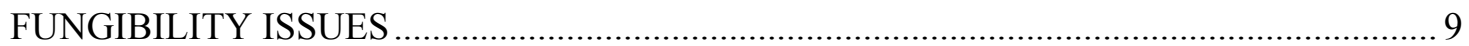

4.4 CASE STUDY: THE KINDER MORGAN EXPERIENCE …........................................... 9

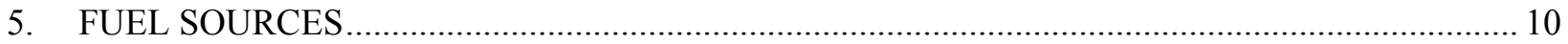

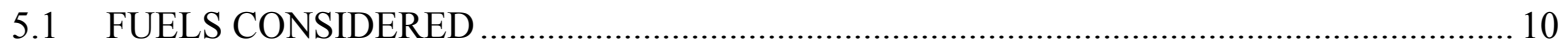

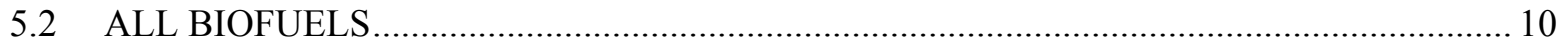

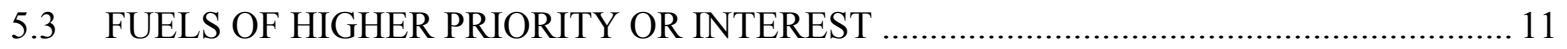

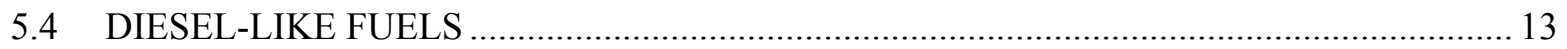

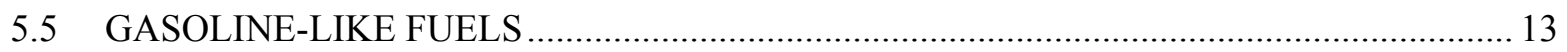

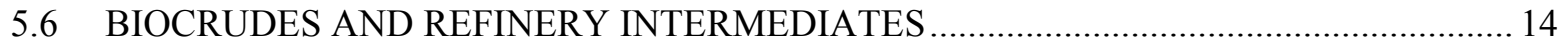

5.7 SHIPPING PYROLYSIS OIL AS CRUDE OIL OR CO-MINGLED WITH CRUDE ........... 14

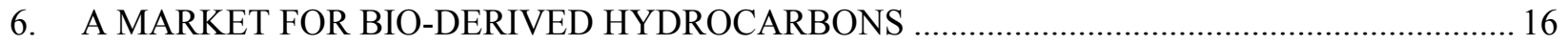

7. ENTRY POINTS FOR BIO-DERIVED PRODUCTS INTO FUEL INFRASTRUCTURE .............. 19

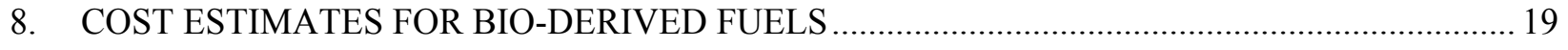

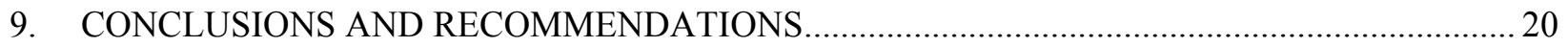

10. REVIEW OF COMMENTS RECEIVED AND SUGGESTED MODIFICATIONS OR

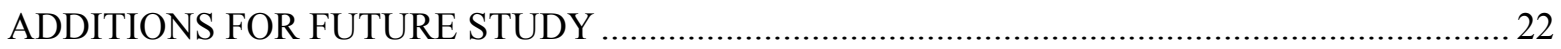

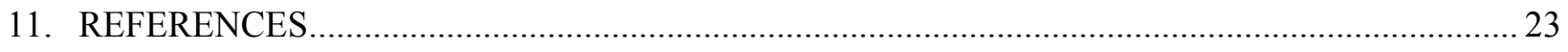

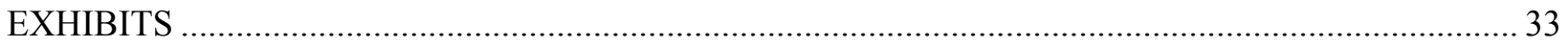




\section{LIST OF EXHIBITS}

\section{Oil Pipelines}

E.1. Products of the Largest U.S. Interstate Oil Pipeline Companies

E.2. Pipeline Descriptions of the Largest U.S. Interstate Oil Pipeline Companies

E.3. Maps of the Pipelines and Terminals of the Largest U.S. Interstate Oil Pipeline Companies

\section{Hazardous Materials Transport}

E.4. Transportation Options for Hazardous Fuels

\section{Distribution Chain}

E.5. Inserting Biofuels into the Current Distribution Chain

\section{Costs}

E.6. Projected Capital and Operating Costs for FAME, Pyrolysis Oil, Ethanol, Methanol, Hydrogen, and Fischer-Tropsch

E.7. Cost Summary for Several Biofuels

\section{Policy Drivers}

E.8. Policy Drivers for Increased Biofuels Use

\section{Diesel Fuels}

E.9. FAME (Fatty Acid Methyl Esters)—Properties

E.10. FAME - Compatibility and Environmental Issues

E.11. Green Diesel-Properties

E.12. Green Diesel - Compatibility and Environmental Issues

E.13. F-T (Fischer-Topsch Fuel)_Properties

E.14. F-T - Compatibility and Environmental Issues

E.15. Algae Biodiesel-Properties

E.16. Algae Biodiesel-Compatibility and Environmental Issues

E.17. DME (Dimethyl Ether)—Properties

E.18. DME - Compatibility and Environmental Issues

E.19. Glyme-Properties

E.20. Glyme - Compatibility and Environmental Issues

E.21. Ethanol-Properties

E.22. Ethanol - Compatibility and Environmental Issues

E.23. Sesquiterpene (Farnesene)-Properties

E.24. Sesquiterpene (Farnesene) - Compatibility and Environmental Issues

\section{Gasoline Fuels}

E.25. Green Gasoline-Properties

E.26. Green Gasoline - Compatibility and Environmental Issues

E.27. F-T (Fischer-Tropsch Fuel)_-Properties

E.28. F-T - Compatibility and Environmental Issues

E.29. Ethanol-Properties

E.30. Ethanol-Compatibility and Environmental Issues

E.31. Biobutanol-Properties

E.32. Biobutanol - Compatibility and Environmental Issues

E.33. Methanol-Properties

E.34. Methanol-Compatibility and Environmental Issues 
E.35. Propanol-Properties

E.36. Propanol-Compatibility and Environmental Issues

E.37. Higher Carbon Alcohols-Properties

E.38. Higher Carbon Alcohols_-Compatibility and Environmental Issues

\section{Biocrude and Intermediates}

E.39. Pyrolysis Oil—Properties

E.40. Pyrolysis Oil-Compatibility and Environmental Issues

E.41. Syngas-Properties

E.42. Syngas - Compatibility and Environmental Issues

E.43. Lignin Liquids-Properties

E.44. Lignin Liquids - Compatibility and Environmental Issues

E.45. Sugar and Alcohols-Properties

E.46 Sugar and Alcohols - Compatibility and Environmental Issues

E.47. Terpenes-Properties

E.48. Terpenes - Compatibility and Environmental Issues

E.49. Isoprenes-Properties

E.50. Isoprenes-Compatibility and Environmental Issues

\section{Others}

E.51. Methane-Properties

E.52. Methane - Compatibility and Environmental Issues

E.53. Hydrogen-Properties

E.54. Hydrogen - Compatibility and Environmental Issues

\section{LIST OF FIGURES}

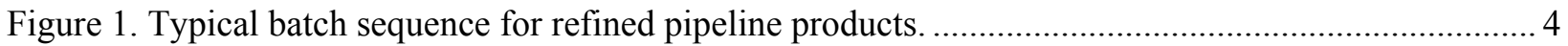

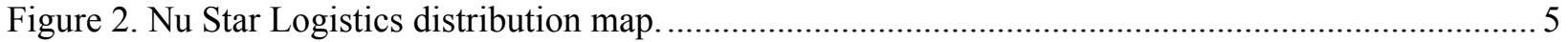

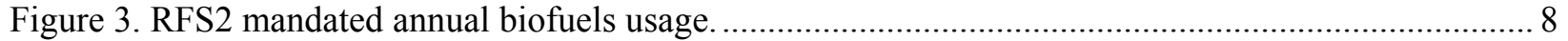

\section{LIST OF TABLES}

Table 1. Distribution problems related to biofuels and possible fixes ................................................ 7

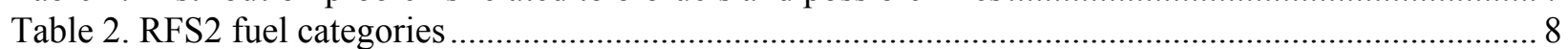

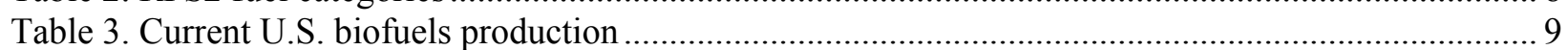

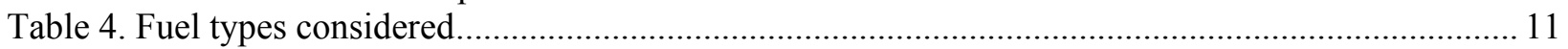

Table 5. Detailed summary table for fuels considered to be of higher priority or greater interest ............. 12

Table 6. Representative crude requirements for pipeline shipments ...................................................... 16

Table 7. Commonly traded fuel blending streams and refinery intermediates ..................................... 18

Table 8. Possible entry points for bio-derived materials into petroleum fuel infrastructure....................... 19

Table 9. Summary of capital and operating costs for several biofuels facilities.................................. 20

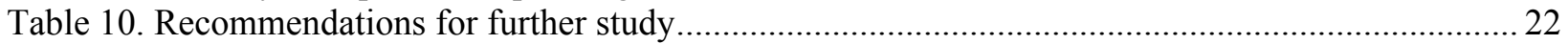





\section{PURPOSE}

\subsection{PURPOSE OF STUDY}

The purpose of this study is to summarize the various barriers to more widespread distribution of biofuels through our common carrier fuel distribution system, which includes pipelines, barges and rail, fuel tankage, and distribution terminals, and with a special focus on biofuels, which may come into increased usage in the future. Addressing these barriers is necessary to allow the more widespread utilization and distribution of biofuels, in support of a renewable fuels standard and possible future low-carbon fuel standards. By identifying these barriers early, for fuels not currently in widespread use, they can be addressed in related research and development. These barriers can be classified into several categories, including operating practice, regulatory, technical, and acceptability barriers. Possible solutions to these issues are discussed, including compatibility evaluation, changes to biofuels, regulatory changes, and changes in the distribution system or distribution practices. No actual experimental research has been conducted in the writing of this report, but results are used to develop recommendations for future research and additional study as appropriate.

This project addresses recognized barriers to the wider use of biofuels in the areas of development of codes and standards, industrial and consumer awareness, and materials compatibility issues.

Specific information tasks for the report include the following. Where possible, the information provided is linked to characteristics of specific biofuels, both current and emerging.

- Background and current operating practices. Fuel blending, pipelines, and distribution practices have developed over a long period of time and operate very efficiently and safely for fuels of specific types. This section will describe how the current pipeline and distribution system are constructed and operated and how this may limit the ability to refinery-blend and distribute biofuels.

- Regulatory barriers to expanded distribution of biofuels. Fuels that are shipped over common carrier distribution must be acceptable to all parties receiving the fuel, and this has resulted in the development of fungibility specifications for fuels. Fuels accepted by pipelines must generally meet fungibility specifications, compatibility specifications, and all legal requirements. This section will describe how current fungibility specifications and pipeline specifications affect the ability to refinery-blend and distribute biofuels.

- Technical barriers to pipeline distribution of biofuels. Legal requirements and fungibility specifications aside, there may also be valid compatibility reasons for not introducing specific biofuels into the common carrier distribution system. This section will discuss the actual physical and technical barriers to biofuel distribution which must be solved to allow the more widespread distribution of biofuels.

- Additional barriers and concerns. This section will describe other barriers to more widespread distribution of biofuels which do not fall readily into the other categories. Examples of these include cross contamination of product, ground water contamination, consumer acceptance and perception, lack of operating experience with a new fuel, and compatibility concerns with existing and future engines and vehicles.

- Possible solutions to problems outlined. The barriers outlined above can be overcome by a number of means, some of which are most applicable to a given barrier and some of which may be easier or more difficult to implement. These solutions fall into the categories of verification of performance 
and compatibility of possible future biofuels, chemical modification of biofuels, changes in current fuel specifications, modifications of fuel distribution procedures and operating practices, or modifications to the current fuel distribution system.

\subsection{DEFINITION OF FUNGIBILITY}

Fungible fuels are those fuels in common use, with common specifications, distributed in a comingled manner, and with sufficient specifications and quality control that they, within a given type, can be substituted for each other without concern of source or end use. Fungible fuels of specific types can be intermixed during distribution and storage without concerns relative to quality or specifications. Fuel specifications are published by a number of regulatory agencies, including ASTM, the U.S.

Environmental Protection Agency, and state agencies, and then adopted as controlling specifications for the receipt, distribution, and delivery of fuels on common carrier systems. There are many fungible fuel specifications, and they vary by fuel type, fuel grade, area of the country where sold, and season [26, 37, $40,50,61,95,102,118,125,145,149,162]$.

\subsection{DEFINITION OF COMPATIBILITY}

Compatible fuels are fuels that would be considered compatible with the infrastructure transporting them, both from the standpoint of no damage by or to the equipment and from the standpoint of no harm from or to other fuels using the same distribution infrastructure [104]. Compatible fuels would also be suitable for use in the vehicle or application intended, in a manner indistinguishable from other fuels. Distribution system compatibility in a fuel may require additional specifications to be met, beyond a fuel's regulated and performance specifications, and these additional requirements are normally included in a fungible fuel specification.

\section{DESCRIPTION OF FUEL MANUFACTURING AND DISTRIBUTION IN THE UNITED STATES}

The following description of petroleum refining and distribution is taken from public sources on this subject, ranging from books to company and association websites. This description is intended to set the stage for a discussion of the differences between biofuels and petroleum-derived fuels and how these differences might affect distribution operations.

Petroleum fuels are manufactured in the United States from crude oil at oil refineries and are then distributed to terminals for final distribution to service stations and end users. Most commonly, crude is received at refineries by pipeline, barge, tanker, or rail and distributed by pipeline, rail, barge, or truck.

Most crude oil and finished fuels are moved by pipeline. The United States consumes about 19.5 million barrels per day of finished petroleum-based fuels, mainly as gasoline, diesel fuel, jet fuel, and heating oil. Of this, $43 \%$ is refined in the United States, and 57\% is received from other countries [152]. U.S. oil refining, fuel distribution, and fuel specifications have grown and evolved over many years to meet demand, product requirements, and quality requirements and now represent a large entrenched infrastructure and a correspondingly large investment, designed specifically for processing and distribution of petroleum-based products. 


\subsection{CRUDE REFINING}

In the processing of crude oil, an oil refinery uses distillation (separation by boiling point) to split crude into a number of fractions for further processing at more specialized process units. Distillation is also used at the output of many of these units to separate finished streams from materials recycled for further processing. Various types of process units can remove sulfur, nitrogen, or oxygen, add hydrogen, reshape molecules, or split or combine molecules. These individual refinery streams are then transferred to blending operations where they are combined to produce finished fuels of required specifications. The balancing of a refinery operation is complex and adjusted both daily and seasonally to compensate for product demands, product shipping cycles, crude characteristics, and process unit operation. Diesel fuel is typically composed of three to five blending streams and gasoline of five to seven blending streams, which are blended to meet the specifications for the given product, season, and region of use. Products can be blended in real time, on line, and immediately put into a pipeline or other form of transportation or batched to storage tanks for later shipment.

\subsection{PIPELINE DISTRIBUTION}

The majority of the distribution infrastructure, mainly pipelines, tanks, and related equipment, is composed of low carbon and low alloy steels, and controlling rust and corrosion is of primary importance. This is largely monitored by a series of standard rust and corrosion tests and periodic thickness measurements and controlled through the use of corrosion and rust inhibitor additives. Generally, pipelines only allow specific additives to be used, at minimum concentrations necessary to achieve a desired result. Petroleum products leaving a refinery will often be above ambient temperature and will contain some dissolved water from various refining operations. In addition, water can sometimes enter finished products through storage tanks or by contact in barges and tankers. With time and cooling, this water will drop out in storage tanks and can be disposed of. Storage tanks are designed to allow the accumulation of water and dirt for periodic removal. Since water bottoms are often considered hazardous waste, there is limited opportunity for continuous removal and disposal at product terminals. As long as the water or dirt is not reentrained into product being sold, it causes no harm to remain in contact with petroleum-derived fuels, although bacteria growth must be controlled at the water-petroleum interface. Tank inlets and suctions are designed to minimize stirring of a product during normal operations to prevent reentrainment of water or dirt.

Pipelines run products in cycles, with batches of one type of product being followed by a batch of another product. Large batches of a given product may originate from several refineries and breakout tanks and end up at multiple terminals along a pipeline. Fungibility allows the co-mingling of product without concern for source or end user. Products follow a defined sequence to minimize cross-contamination and to allow ability to detect product and batch changes. Normally, batch detection is done by monitoring for fluid density changes between the sequential batches. Between batches, a small amount of co-mingled product, known as interface or transmix, is generated and is normally segregated for refractionation to diesel and gasoline or returned to a refinery for processing. Figure 1 shows a typical batch sequence for refined pipeline products.

\subsection{TERMINAL BLENDING}

At a product terminal, individual tanks store specific products, which are then sent to a truck loading rack for distribution to service stations or other users. Tanker trucks can have one large compartment or several smaller compartments. Occasionally, smaller pipelines may send product directly to an end user such as an airport or for a dedicated service station located near a terminal. For biofuels, the loading rack at a product terminal is currently the most common entry point into the distribution system. On-line blending equipment is used to blend a petroleum-based product with biofuels, proportionally by volume, 


\section{Petroleum Products Batching}

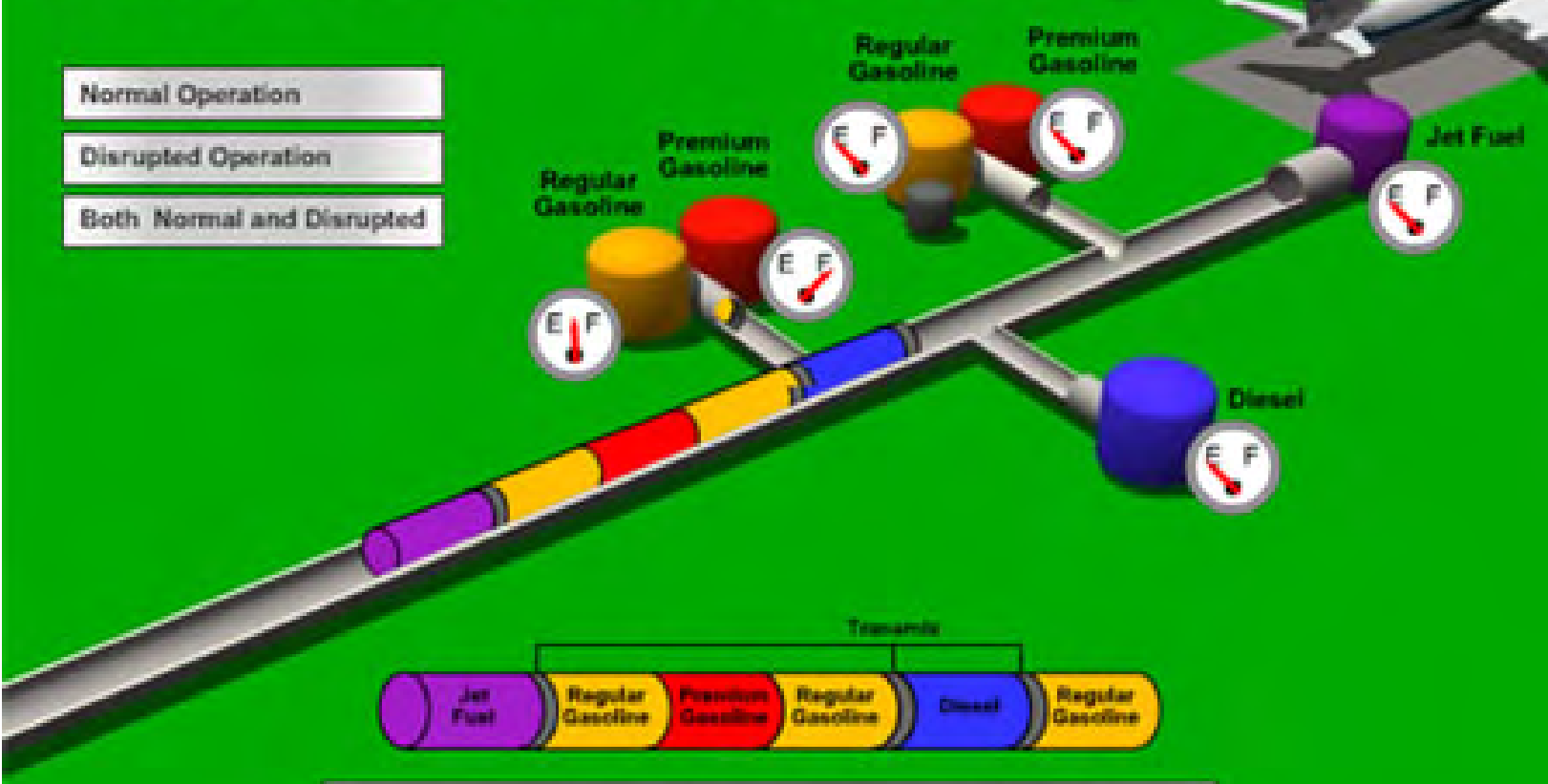

Through a single pipeline, we transport dozens of products and grades of gasoline at once through a process called "batching" This process makes it possible for pipeline operators to meet the diverse energy needs of the nation.

Source: (www.pipeline101.com)

Figure 1. Typical batch sequence for refined pipeline products. [167]

during truck loading. The biofuels (ethanol and fatty ethyl methyl esters, or FAME) are brought into a terminal by truck, rail, or barge and kept in dedicated tanks until blended. FAME is the most common form of biodiesel in use today and is often referred to as biodiesel. In this report, the term FAME is used to describe $100 \%$ FAME, FAME biodiesel is used to describe blends of FAME and diesel fuel, and biodiesel is used to describe other forms of bio-derived diesel fuels.

Refinery blending of products differs in several ways from blending done at a terminal. First, a refinery has a number of blending streams available and generally has multiple options to achieve a fuel specification. A refinery has an analytical laboratory and on-line monitoring equipment that allows blending to product specifications. A refinery also has storage tankage and more options for dealing with any off-specification product. In contrast, a terminal has only the capability to blend to volume percentage, during truck loading, between two components. These blended components must be designed to meet a final product specification after blending, since a terminal does not typically have the capability (in the form of additional blend streams, additional storage tankage, or analytical equipment) to blend to specification or to adjust off-specification product. 


\subsection{EXAMPLE PIPELINE DISTRIBUTION MAP}

Figure 2 provides an example of part of the petroleum distribution infrastructure in the United States. The map displays the distribution and storage holdings of $\mathrm{Nu}$ Star Logistics, one of the ten largest U.S.-based pipeline companies, with over 8000 miles of pipeline transporting over 800,000 barrels per day. This particular pipeline network (including a variety of pipeline types, such as crude, refined, ammonia, singleuse, etc.) is centered in the Midwest, as are the crude oil storage facilities. There are a number of product terminals on the east and west coasts that are not served by a $\mathrm{Nu}$ Star pipeline. These are either reached by rail, truck, barge (likely for port cities), third-party pipelines, or a combination thereof. This particular map is included for illustrative purposes and does not portray the entire U.S. fuel distribution infrastructure.

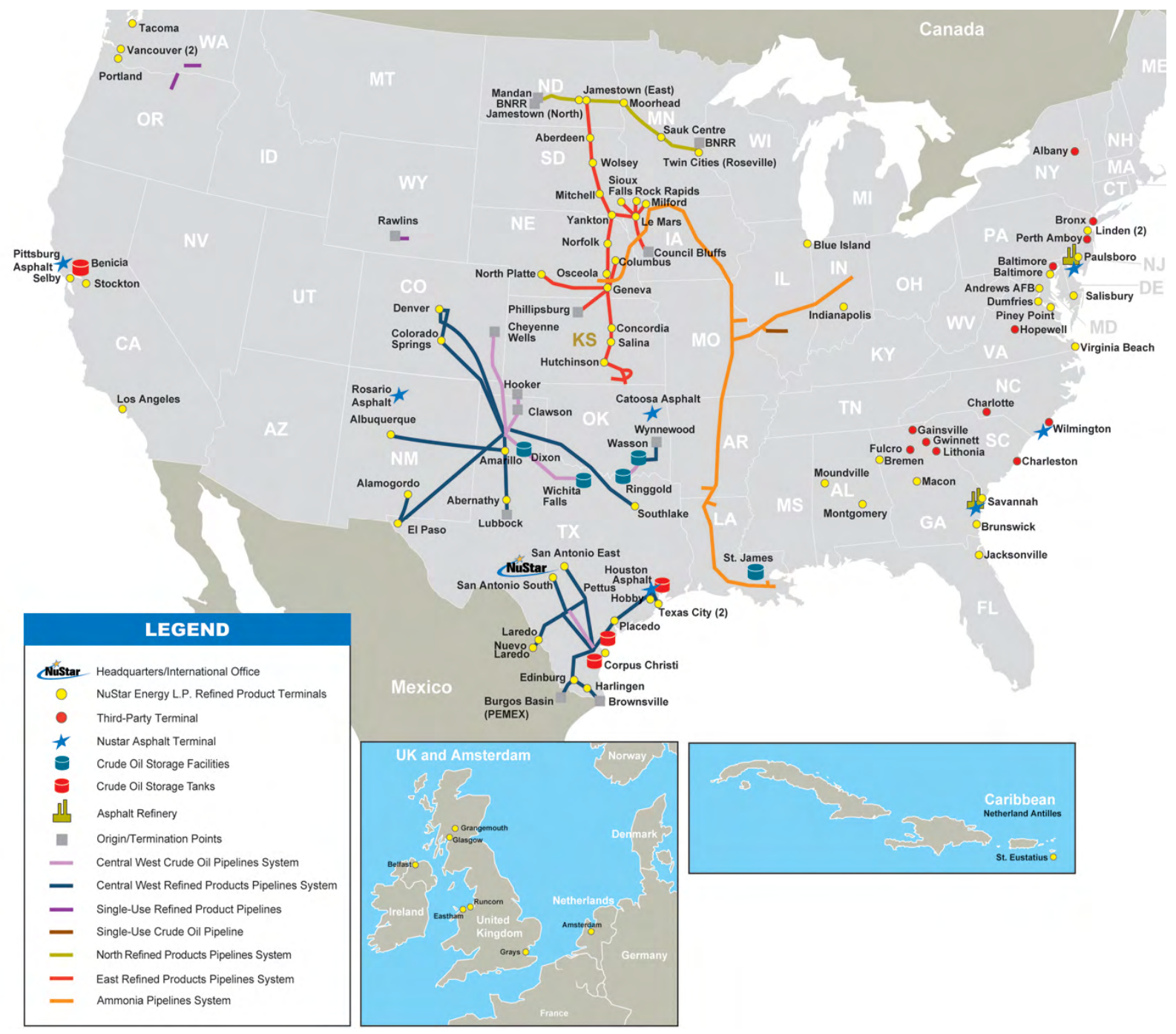

Figure 2. Nu Star Logistics distribution map. [118] Note that there are at least ten major pipeline companies operating in the United States, and this particular map has been included to illustrate one of them. It does not provide a total picture of pipeline infrastructure. 


\section{INCORPORATING BIOFUELS INTO THE CURRENT DISTRIBUTION SYSTEM}

\subsection{ISSUES WITH OXYGENATED BIOFUELS}

Current biofuels (ethanol and FAME) contain oxygen and are polar molecules. This polarity makes them behave differently than hydrocarbon fuels and results in the need for different handling and distribution practices. This polarity results in a greater affinity for other things, such as water, dirt, and surfaces. Water, which is normally present in the fuel distribution system for reasons described above, can be dissolved into a biofuel at greater amounts than in a corresponding petroleum fuel, and this can result in product quality problems during use. FAME can dissolve substantially more water than can petroleum fuels $[111,114]$, and ethanol is highly soluble with water and can dissolve large amounts of water into an ethanol-gasoline mix; ethanol can segregate out of an ethanol gasoline mix and into a water phase [42]. Dissolved water in biofuels can also contribute to corrosion and stress corrosion cracking. Stress corrosion cracking of mild steel may be of particular concern with ethanol [124], and further study of ethanol-induced corrosion is one of the recommendations of this report. The polarity of ethanol and FAME can also make the separation of dirt and water more difficult or slower than for petroleum fuels. Low-level FAME contamination in jet fuel is also of current concern and is being studied. Possible solutions to this issue include careful batch sequencing or the use of a separate, parallel pipeline to segregate jet fuel from FAME biodiesel.

\subsection{CURRENT PRACTICES AND PROPOSED SOLUTIONS}

The current practices of adding FAME and ethanol during truck loading minimizes the opportunity for contact with water and dirt but may be more difficult for the larger volumes of biofuels required in the

future. Expansion of the use of bio-derived fuels would be easier if they did not require separate shipping to multiple distribution points but could be handled with existing infrastructure at refineries. The problems cited can be alleviated by modifications to the fuels themselves or by modifications to the distribution equipment and practices. Table 1 outlines some of the distribution problems associated with biofuels usage, with a variety of solutions including fuel, equipment, or operating practice modifications.

Examination of the table indicates the possibility of multiple or combined solutions ranging from product changes, equipment modifications, and changes in operating practices. None of these changes are particularly difficult from a science or engineering viewpoint, but some may require considerable investment in modifying distribution or refining equipment. It is likely that final solutions will be a combination of several of these options. Additional study, development, and research by the Department of Energy and the companies involved should provide the necessary information and guidance to allow such decisions to be made. 
Table 1. Distribution problems related to biofuels and possible fixes

\begin{tabular}{|l|l|l|l|}
\hline \multicolumn{1}{|c|}{$\begin{array}{c}\text { Distribution } \\
\text { problem }\end{array}$} & \multicolumn{1}{|c|}{ Fuel fix } & \multicolumn{1}{c|}{ Equipment fix } & \multicolumn{1}{c|}{ Operating fix } \\
\hline Water in product & $\begin{array}{l}\text { Less polar form of biofuel, } \\
\text { such as butanol vs. ethanol or } \\
\text { converting oils or fats to } \\
\text { hydrocarbons rather than } \\
\text { esters }\end{array}$ & $\begin{array}{l}\text { Design tankage to minimize } \\
\text { contact between water and } \\
\text { product, use of separators to } \\
\text { remove water }\end{array}$ & $\begin{array}{l}\text { Drain water bottoms more } \\
\text { frequently, combined with } \\
\text { careful monitoring* }\end{array}$ \\
\hline $\begin{array}{l}\text { Dirt in product } \\
\text { contamination of } \\
\text { products }\end{array}$ & Less polar form of biofuel & $\begin{array}{l}\text { Design tanks to reduce } \\
\text { reentrainment of dirt, use } \\
\text { filtration to remove dirt }\end{array}$ & $\begin{array}{l}\text { Keep tanks clean, combined } \\
\text { with careful monitoring* }\end{array}$ \\
\hline $\begin{array}{l}\text { Corrosion and } \\
\text { rust of mild or } \\
\text { low alloy steel }\end{array}$ & $\begin{array}{l}\text { Make fuel more petroleum- } \\
\text { like, reduce dissolved water, } \\
\text { reduce fuel polarity, selection } \\
\text { and use of effective corrosion } \\
\text { inhibitors }\end{array}$ & $\begin{array}{l}\text { Equipment for better interface } \\
\text { detection and separation of } \\
\text { transmix }\end{array}$ & $\begin{array}{l}\text { Batch sequencing, combined } \\
\text { with careful monitoring and } \\
\text { separation of transmix* }\end{array}$ \\
\hline $\begin{array}{l}\text { Material } \\
\text { compatibility } \\
\text { other than } \\
\text { corrosion and rust }\end{array}$ & $\begin{array}{l}\text { Make fuels more petroleum- } \\
\text { like }\end{array}$ & $\begin{array}{l}\text { Change to more compatible } \\
\text { materials }\end{array}$ & $\begin{array}{l}\text { Monitoring and maintenance, } \\
\text { corrosion inhibitors* }\end{array}$ \\
\hline
\end{tabular}

*Current practices may need to be executed more frequently with biofuels.

\section{CURRENT STATE OF THE MARKET}

\subsection{RFS2 REQUIREMENTS}

The Renewable Fuel Standard (RFS1) was established by the U.S. Energy Policy Act of 2005. It was the first specific renewable fuel volume mandate in U.S. history. It mandated that by 2012 at least 7.5 billion gallons of renewable fuel be blended into gasoline annually. RFS1 delineated three specific types of renewable fuel: grain ethanol, ethanol from cellulosic sources, and biomass-based diesel, which was defined but not mandated. Under the Energy Independence and Security Act of 2007, the Renewable Fuel Standard was revised and its scope expanded in an effort to accelerate energy independence and security, to keep pace with emerging renewable fuel technologies, and to provide greater detail concerning the ways in which the mandate is to be met. This set of extensive revisions became known as RFS2 [51].

RFS2 significantly increases the renewable fuel volume mandate, starting with 9 billion gallons required by 2008 and increasing yearly to 36 billion gallons by 2022. The mandate also applies to blending with diesel fuels as well as with gasoline. Consequently, the number and types of renewable fuels that fall under the RFS2 are increased over those of RFS1. Renewable fuels covered under RFS2 now fall into one of five categories: cellulosic biofuel made from cellulose, hemicellulose, or lignin sources; biomass-based diesel defined as any non-co-processed diesel fuel from renewable sources; advanced biofuel, which is defined as any renewable fuel not made from corn starch; renewable biofuel, which is meant to include corn-based ethanol; and a special class that includes cellulosic-based diesel fuel. Each of these categories has its own corresponding volume mandate and lifecycle greenhouse gas emissions requirements, summarized in Figure 3 and Table 2. 


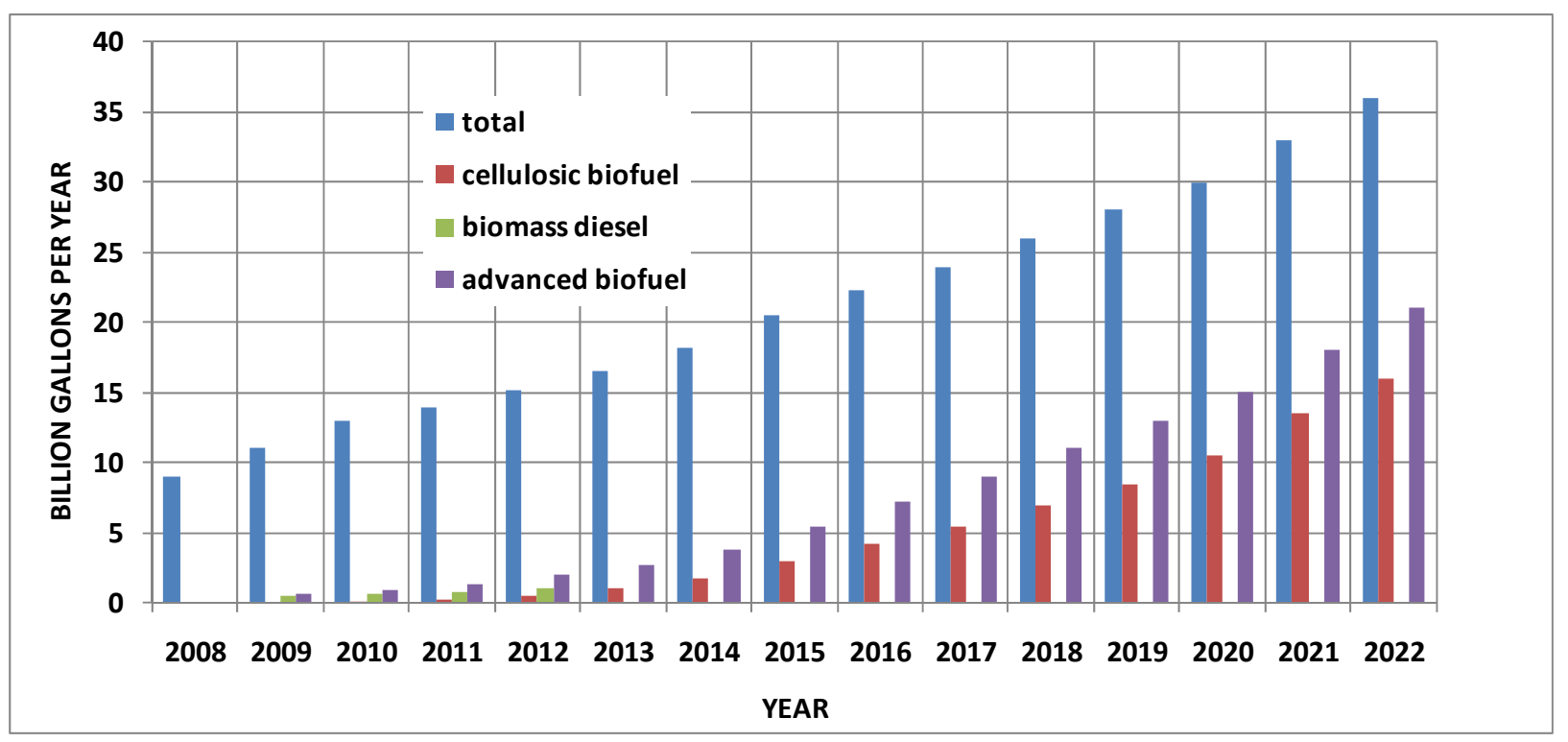

Figure 3. RFS2 mandated annual biofuels usage. [51]

Table 2. RFS2 fuel categories [51]

\begin{tabular}{|l|c|c|c|c|c|}
\hline \multicolumn{1}{|c|}{ Fuel type } & $\begin{array}{c}\text { 2010 mandated } \\
\text { volume } \\
\text { (billion gallons) }\end{array}$ & $\begin{array}{c}\text { 2022 mandated } \\
\text { volume } \\
\text { (billion gallons) }\end{array}$ & $\begin{array}{c}\text { Life-cycle GHG } \\
\text { reductions^ }\end{array}$ & $\begin{array}{c}\text { Possible fuels } \\
\text { included }\end{array}$ & $\begin{array}{c}\text { Example } \\
\text { feedstocks }\end{array}$ \\
\hline Cellulosic biofuel & 0.1 & 16 & $60 \%$ & Ethanol & $\begin{array}{c}\text { Corn stover, } \\
\text { switchgrass }\end{array}$ \\
\hline $\begin{array}{l}\text { Biomass-based } \\
\text { diesel }\end{array}$ & 0.65 & TBD & $50 \%$ & $\begin{array}{c}\text { FAME, Green } \\
\text { diesel, Algae } \\
\text { biodiesel }\end{array}$ & $\begin{array}{c}\text { Soy, palm, } \\
\text { rapeseed, algae } \\
\text { oil }\end{array}$ \\
\hline Advanced biofuel & 0.95 & 21 & $50 \%$ & $\begin{array}{c}\text { Green gasoline } \\
\text { Sugar cane, } \\
\text { agricultural } \\
\text { residue }\end{array}$ \\
\hline Renewable biofuel & $12.95-\mathrm{CBA}^{*}$ & $36-\mathrm{CBA}^{*}$ & $20 \%$ & Ethanol & Corn starch \\
\hline $\begin{array}{l}\text { Cellulosic } \\
\text { biodiesel }\end{array}$ & N/A & N/A & $60 \%$ & $\begin{array}{c}\text { Pyrolysis oil- } \\
\text { based biodiesel }\end{array}$ & Wood chips \\
\hline
\end{tabular}

* Can be adjusted-Renewable biofuel volume is the difference between the total yearly volume mandate and the sum of the individual volume mandates for the cellulosic, biomass-based diesel, and advanced categories. The EPA can determine that the yearly mandate for an individual category cannot feasibly be met, but it does not have the authority to reduce the total RFS2 volume mandate. Renewable biofuels derived from grain are limited to 15 billion gallons per year.

${ }^{\wedge}$ Each fuel category has a corresponding life-cycle greenhouse gas (GHG) emissions reduction requirement when compared to the petroleum-based fuel counterpart (either gasoline or diesel).

\# Cellulosic biodiesel is a special category that is comprised of cellulosic biomass-based diesel fuel. When this fuel also provides a greenhouse gas emissions reduction of at least $60 \%$ compared to petroleum diesel, the fuel can be used to satisfy either the cellulosic requirement or the biomass-based diesel requirement. 
The RFS2 regulations also provide specific rules governing land use for biofuel feedstocks. Numbers and credits are affixed to each gallon of qualifying biofuel produced. Once the biofuel is transported to the end user, the credits are detached and become tradable commodities and serve as proof that individual mandates have been met by the fuel manufacturer, blender, or importer. All of these improvements to RFS1 create a policy climate that places emphasis on both biofuel diversification and biofuel cost. RFS2 will play a dominating role in biofuels utilization for the foreseeable future.

\subsection{CURRENT PRODUCTION OF ETHANOL AND FAME}

Table 3 summarizes available information concerning current or recent biofuels production and capacity in the U.S. for biofuels discussed in this report.

Table 3. Current U.S. biofuels production

\begin{tabular}{|c|c|c|c|}
\hline Fuel & $\begin{array}{c}\text { U.S. production } \\
\text { (billion gallons) }\end{array}$ & $\begin{array}{c}\text { U.S. production capacity } \\
\text { (billion gallons) }\end{array}$ & Year of available data \\
\hline FAME $[171]$ & 0.545 & 2.74 & 2009 \\
\hline Ethanol $[170]$ & 11.88 & 13.03 & 2010 \\
\hline
\end{tabular}

\subsection{HOW THE CURRENT MARKET DEALS WITH COMPATIBILITY AND FUNGIBILITY ISSUES}

The two major current biofuels in the United States, ethanol as a gasoline blending component and FAME as a diesel blending component, are either expressly or de facto prohibited in pipelines operated by most of the ten largest pipeline companies. The compatibility and fungibility issues associated with both ethanol and FAME, as well as the other biofuels in this report, are discussed in greater detail later in this report and in the Excel workbook. The most notable compatibility issues are water solubility and stress corrosion cracking for ethanol, and fuel contamination and cold flow performance for FAME. Five of the ten largest U.S. pipeline companies expressly prohibit alcohols and ethers as "blending components in gasoline at (refinery) origin." Six of the ten companies either expressly prohibit FAME or place freeze and cloud point restrictions on diesel fuel that serve as de facto prohibitions on FAME blending at the refinery $[26,37,40,50,61,95,102,118,125,145,149,162]$.

While there are emerging exceptions to the above prohibitions (see the following discussion of Kinder Morgan's experience with biofuels fungibility), ethanol and FAME biodiesel are generally not transported via the existing petroleum pipeline infrastructure. They are generally rack-blended with gasoline or diesel fuel at distribution terminals, and the mixtures are then sent to service stations via truck.

\subsection{CASE STUDY: THE KINDER MORGAN EXPERIENCE}

Kinder Morgan Energy Partners, one of the largest oil pipeline companies in the United States, is one of the several companies that have successfully demonstrated biofuel transport through the petroleum pipeline infrastructure [95]. In 2008, Kinder Morgan began shipping neat ethanol through a 115-mile stretch of gasoline pipeline in Central Florida. To prevent or mitigate the major impedances to ethanol pipeline shipment — namely, water solubility, stress corrosion cracking, and the cleaning effect— the pipeline was first cleaned and all potential water sources were removed. Kinder Morgan utilized a proprietary mix of corrosion inhibitors in an effort to prevent stress corrosion cracking. Neat ethanol is, as of early 2010, routinely shipped on this pipeline, and no problems have been reported. 
Kinder Morgan has also experimented with shipping FAME biodiesel over the Plantation pipeline network located in the southeastern United States. Initially, a B5 blend was shipped over 500 miles of diesel pipeline. The critical issue of FAME contamination of jet fuel was bypassed due to the existence of a parallel pipeline that allowed jet fuel and FAME biodiesel to remain segregated. The results of this experiment were ultimately positive. As of early 2010, Kinder Morgan allows the shipment of B2, B5, and/or B100 over 8000 miles of pipeline.

This case study demonstrates that while the water solubility, cleaning effect, contamination, and stress corrosion issues associated with ethanol and FAME pipeline shipping are significant, they are not insurmountable. Proper cleaning, chemical additives, segregation/batch sequencing, parallel pipelines, and monitoring can either eliminate or greatly mitigate these problems and make ethanol and FAME pipeline shipment possible.

\section{FUEL SOURCES}

\subsection{FUELS CONSIDERED}

The biofuels considered in this report are discussed in three sections, with more detail as the options are narrowed to biofuels considered to be of greater importance and higher likelihood for future use. The three sections are "all biofuels," "all biofuels of higher priority," and "biofuels of higher priority which would benefit from further study on certain key questions." Each of these fuel sections is also classified by end use by separation into four categories: gasoline-like fuels, diesel-like fuels, biocrudes and refinery intermediates, and other fuels. Gasoline-like and diesel-like fuels are biofuels that are intended for combustion in spark-ignition and compression-ignition engines, respectively, and possess physical and chemical properties that are intended to be similar to gasoline or diesel fuel. These categories include fuels such as ethanol, butanol, and FAME. The biocrudes and intermediates category contains biofuels that are not fuels until they are further refined, in much the same way as petroleum crude is further refined into gasoline, diesel, etc. before reaching the end-user. Biocrudes and intermediates include pyrolysis oil and syngas. The other fuels category includes methane and hydrogen, fuels that do not have similar properties to either gasoline or diesel but nevertheless can be utilized in dedicated vehicles. These latter fuels are examined with the understanding that they, by nature, cannot be incorporated into the existing petroleum distribution infrastructure, but rather their own distribution infrastructures are extensive enough to warrant research into the fungibility prospects of their biomass-based equivalents.

\subsection{ALL BIOFUELS}

Table 4 lists all the fuels considered in the preparation of this report, classified by the types discussed previously. Each of these fuels is discussed in detail in the exhibits at the end of this report. Each fuel has two exhibits. The first consists of available fuel properties and environmental impact data for each fuel as compared to its petroleum-derived counterpart. The second exhibit consists of materials compatibility data, vehicle compatibility data, transporting precautions, environmental and health concerns, fungibility and distribution issues, current production, and overall advantages and disadvantages of distribution and use of each particular fuel, along with references.

Also included in the exhibits is information concerning the ten largest oil pipeline companies in the United States in terms of daily transported volume. This information includes pipeline network location and mileage, products transported, and prohibitions, particularly how these relate to biofuel distribution. Other exhibits include federal hazmat transport regulations, information on where specific biofuels can theoretically be inserted into the distribution chain, capital and operating cost analysis for several types of biofuel production facilities, and a list of federal and state policies and initiatives designed to drive 
increased biofuel usage. (The information contained in the exhibits can be acquired from the authors as an Excel workbook.)

The list of fuels considered in Table 4 was narrowed to those which are of higher priority or of greater interest to DOE during preliminary discussions of results. These fuels are discussed in greater detail in the next section.

Table 4. Fuel types considered

\begin{tabular}{|l|c|c|c|c|}
\hline \multicolumn{1}{|c|}{ Fuels } & Diesel-like fuels & $\begin{array}{c}\text { Gasoline-like } \\
\text { fuels }\end{array}$ & $\begin{array}{c}\text { Biocrudes and } \\
\text { intermediates }\end{array}$ & Other fuels \\
\hline FAME & $\mathrm{X}$ & & & \\
\hline Green diesel & $\mathrm{X}$ & & & \\
\hline F-T diesel & $\mathrm{X}$ & & & \\
\hline Algae biodiesel & $\mathrm{X}$ & & & \\
\hline DME & $\mathrm{X}$ & & & \\
\hline Glyme & $\mathrm{X}$ & & & \\
\hline Ethanol-diesel blends & $\mathrm{X}$ & & & \\
\hline Sesquiterpene & $\mathrm{X}$ & & & \\
\hline Green gasoline & & $\mathrm{X}$ & & \\
\hline F-T gasoline & & $\mathrm{X}$ & & \\
\hline Ethanol & & $\mathrm{X}$ & & \\
\hline Biobutanol & & $\mathrm{X}$ & & \\
\hline Methanol & & $\mathrm{X}$ & $\mathrm{X}$ & \\
\hline Propanol & & & $\mathrm{X}$ & \\
\hline Higher C alcohols & & & $\mathrm{X}$ & \\
\hline Pyrolysis oils & & & $\mathrm{X}$ & \\
\hline Syngas & & & & \\
\hline Lignin liques & & & & \\
\hline Sugars and alcohols & & & & \\
\hline Terpenes & & & & \\
\hline Isoprene & & & & \\
\hline Methane & & & & \\
\hline Hydrogen & & & & \\
\hline
\end{tabular}

\subsection{FUELS OF HIGHER PRIORITY OR INTEREST}

From Table 4, ten fuels were chosen for examination in greater depth. These fuels are of higher priority or of greater interest as they are most likely to provide a significant portion of bio-derived fuels in the future. These fuels are listed in Table 5, which also summarizes the knowledge we were able to uncover about 
Table 5. Detailed summary table for fuels considered to be of higher priority or greater interest

\begin{tabular}{|c|c|c|c|c|c|c|c|c|c|}
\hline $\begin{array}{c}\text { Compound, fuel, } \\
\text { or component }\end{array}$ & Use, purpose & Advantages & Property issues & Infrastructure issues & $\begin{array}{l}\begin{array}{l}\text { Environmental } \\
\text { characteristics }\end{array} \\
\end{array}$ & $\begin{array}{c}\text { Compatibility } \\
\text { questions }\end{array}$ & $\begin{array}{l}\text { Areas needing } \\
\text { further atudy }\end{array}$ & \begin{tabular}{|c|} 
Cost compared to \\
petroleum derived
\end{tabular} & References \\
\hline FAME (biodiesel) & $\begin{array}{l}\text { Diesel substitute or } \\
\text { blend component }\end{array}$ & $\begin{array}{l}\text { Currently in use, relatively } \\
\text { easy to manufacture, } \\
\text { generally higher cetane }\end{array}$ & $\begin{array}{l}\text { Cold flow, stability, filter } \\
\text { plugging, higher viscosity, } \\
\text { lower energy content }\end{array}$ & $\begin{array}{l}\text { Pick up of dirt and } \\
\text { water, cleaning effect, } \\
\text { contamination of other } \\
\text { fuels, storage stability, } \\
\text { prohibited in most } \\
\text { pipelines }\end{array}$ & $\begin{array}{l}\text { Relatively non-toxic, } \\
\text { biodegerades easily }\end{array}$ & $\begin{array}{l}\text { Problems with terne- } \\
\text { coated steel (older } \\
\text { vehicle fuel tanks), } \\
\text { nitrile and natural } \\
\text { rubber }\end{array}$ & $\begin{array}{l}\text { Shipment over } \\
\text { common carrier } \\
\text { pipelines, cross } \\
\text { contamination on } \\
\text { other fuels }\end{array}$ & $\begin{array}{l}\text { Same to higher } \\
\text { depending on } \\
\text { feedstock }\end{array}$ & $\begin{array}{c}8,17,36, \\
39,89,99, \\
101, \\
111,112 \\
114,139 \\
146\end{array}$ \\
\hline Green diesel & $\begin{array}{l}\text { Diesel substitute or } \\
\text { blend component }\end{array}$ & $\begin{array}{l}\text { Closest to drop-in } \\
\text { replacement, option to } \\
\text { optimize further }\end{array}$ & $\begin{array}{l}\text { Very little information or } \\
\text { production at present, } \\
\text { chemistry may be } \\
\text { somewhat different from } \\
\text { petroleum derived fuels }\end{array}$ & None known & $\begin{array}{l}\text { Similar to petroleum } \\
\text { diesel, well } \\
\text { understood }\end{array}$ & $\begin{array}{l}\text { Similar to petroleum } \\
\text { diesel, well } \\
\text { understood }\end{array}$ & $\begin{array}{l}\text { More definition of } \\
\text { chemistry and } \\
\text { properties, use as a } \\
\text { blending component } \\
\text { or finished fuel } \\
\end{array}$ & Not known & $\begin{array}{c}76,92,115 \\
130,142 \\
155,165\end{array}$ \\
\hline $\begin{array}{l}\text { Fischer-Tropsch } \\
\text { (F-T) diesel }\end{array}$ & $\begin{array}{l}\text { Diesel substitute or } \\
\text { blend component }\end{array}$ & $\begin{array}{l}\text { Generally higher cetane, } \\
\text { zero sulfur, option to } \\
\text { optimize further }\end{array}$ & $\begin{array}{l}\text { Possible cold flow } \\
\text { problems, can be controlled } \\
\text { with chemistry, slightly } \\
\text { lower energy content }\end{array}$ & None known & $\begin{array}{l}\text { Similar to petroleum } \\
\text { diesel, well } \\
\text { understood }\end{array}$ & $\begin{array}{l}\text { Similar to petroleum } \\
\text { diesel, well } \\
\text { understood }\end{array}$ & $\begin{array}{l}\text { Probably none, well } \\
\text { understood }\end{array}$ & Higher & $\begin{array}{l}7,34,86 \\
93,110\end{array}$ \\
\hline Algae biodiesel & $\begin{array}{l}\text { Diesel substitute or } \\
\text { blend component }\end{array}$ & $\begin{array}{l}\text { Completely new source of } \\
\text { fuel with potential for high } \\
\text { volume }\end{array}$ & $\begin{array}{l}\text { Cold flow, stability, filter } \\
\text { plugging, higher viscosity, } \\
\text { lower energy content, } \\
\text { more unsaturates than } \\
\text { fame }\end{array}$ & $\begin{array}{l}\text { Pick up of dirt and } \\
\text { water, cleaning effect, } \\
\text { contamination of other } \\
\text { fuels, storage stability, } \\
\text { prohibited in most } \\
\text { pipelines }\end{array}$ & $\begin{array}{l}\text { Relatively non-toxic, } \\
\text { biodegrades easily }\end{array}$ & $\begin{array}{l}\text { Problems with terne- } \\
\text { coated steel (older } \\
\text { vehicle fuel tanks), } \\
\text { nitrile and natural } \\
\text { rubber }\end{array}$ & $\begin{array}{l}\text { Same as FAME }+ \\
\text { study of detailed } \\
\text { chemistry and } \\
\text { properties, production, } \\
\text { and logistics }\end{array}$ & Not known & 33,108 \\
\hline Green gasoline & $\begin{array}{l}\text { Gasoline substitute } \\
\text { or blend component }\end{array}$ & $\begin{array}{l}\text { Closest to drop-in } \\
\text { replacement, option to } \\
\text { optimize further }\end{array}$ & $\begin{array}{l}\text { Very little information or } \\
\text { production at present, } \\
\text { chemistry may be } \\
\text { somewhat different from } \\
\text { petroleum derived fuels } \\
\end{array}$ & None known & $\begin{array}{l}\text { Similar to petroleum } \\
\text { diesel, well } \\
\text { understood }\end{array}$ & $\begin{array}{l}\text { Similar to petroleum } \\
\text { diesel, well } \\
\text { understood }\end{array}$ & $\begin{array}{l}\text { More definition of } \\
\text { chemistry and } \\
\text { properties, use as a } \\
\text { blending component } \\
\text { or finished fuel } \\
\end{array}$ & Not known & None found \\
\hline $\begin{array}{l}\text { Fischer-Tropsch } \\
\text { (F-T) gasoline }\end{array}$ & $\begin{array}{l}\text { Gasoline substitute } \\
\text { or blend component }\end{array}$ & $\begin{array}{l}\text { Zero sulfur, option to } \\
\text { optimize further }\end{array}$ & $\begin{array}{l}\text { May have slightly lower } \\
\text { energy content }\end{array}$ & None known & $\begin{array}{l}\text { Similar to petroleum } \\
\text { diesel, well } \\
\text { understood }\end{array}$ & $\begin{array}{l}\text { Similar to petroleum } \\
\text { diesel, well } \\
\text { understood }\end{array}$ & $\begin{array}{l}\text { Probably none -well } \\
\text { understood }\end{array}$ & Higher & 93 \\
\hline Ethanol & $\begin{array}{l}\text { Gasoline blend } \\
\text { component }\end{array}$ & $\begin{array}{l}\text { High octane, largest current } \\
\text { biofuel volume, well } \\
\text { understood }\end{array}$ & \begin{tabular}{|l|} 
Lower energy content (up \\
to $28 \%$ MPG penalty), \\
requires special low RVP \\
blend stock (readily \\
available)
\end{tabular} & $\begin{array}{l}\text { Segregation into and } \\
\text { dissolving of water in } \\
\text { distribution system, } \\
\text { cleaning effect, } \\
\text { prohibited in most } \\
\text { pipelines } \\
\end{array}$ & $\begin{array}{l}\text { Miscible in water, } \\
\text { toxic in high } \\
\text { concentrations, } \\
\text { biodegrades easily }\end{array}$ & $\begin{array}{l}\text { Incompatible with } \\
\text { hose and fuel tank } \\
\text { material in older } \\
\text { vehicles, but current } \\
\text { approved as } 10 \% \\
\text { blend in all vehicles } \\
\end{array}$ & $\begin{array}{l}\text { Potential for pipeline } \\
\text { shipments, stress } \\
\text { corrosion cracking }\end{array}$ & $\begin{array}{l}\text { Similar to higher } \\
\text { depending on } \\
\text { feedstock }\end{array}$ & $\begin{array}{c}11,20,21 \\
42,124 \\
143,158 \\
163\end{array}$ \\
\hline Butanol & $\begin{array}{l}\text { Gasoline blend } \\
\text { component }\end{array}$ & $\begin{array}{l}\text { Similar characteristics to } \\
\text { ethanol, but differences } \\
\text { compared to petroleum } \\
\text { gasoline are much less, can } \\
\text { be same or slightly higher } \\
\text { octane, provides more } \\
\text { renewable gallon credits for } \\
\text { same oxygen blend limit } \\
\end{array}$ & $\begin{array}{l}\text { Limited experience with } \\
\text { use of butanol }\end{array}$ & $\begin{array}{l}\text { Goal is to ship blends } \\
\text { over common carrier } \\
\text { pipelines, but currently } \\
\text { prohibited in most } \\
\text { pipelines }\end{array}$ & $\begin{array}{l}\text { Miscible in water } \\
\text { (less than ethanol), } \\
\text { toxic in high } \\
\text { concentrations, } \\
\text { should biodegrade } \\
\text { easily, but requires } \\
\text { more study }\end{array}$ & $\begin{array}{l}\text { Similar characteristics } \\
\text { to ethanol, but } \\
\text { differences compared } \\
\text { to petroleum gasoline } \\
\text { are much less }\end{array}$ & $\begin{array}{l}\text { Properties of various } \\
\text { isomers and isomer } \\
\text { mixtures, shipping } \\
\text { studies for common } \\
\text { carrier distribution } \\
\text { system }\end{array}$ & \begin{tabular}{|l|} 
Not known, \\
probably higher than \\
ethanol
\end{tabular} & $\begin{array}{c}1,6,10,12, \\
25,27,70, \\
103,121, \\
135,154, \\
156\end{array}$ \\
\hline Pyrolysis oil & $\begin{array}{l}\text { Biocrude, refiner } \\
\text { feedstock }\end{array}$ & $\begin{array}{l}\text { Direct route from biomass to } \\
\text { liquid product }\end{array}$ & \begin{tabular}{|l|} 
Stability problems, not \\
miscible with petroleum \\
crude, high water and \\
oxygen content, high \\
viscosity, corrosive, solids \\
content \\
\end{tabular} & $\begin{array}{l}\text { Can't be shipped as } \\
\text { crude oil, must be } \\
\text { stabilized before } \\
\text { storage and shipment }\end{array}$ & $\begin{array}{l}\text { Moderately toxic, } \\
\text { biodegrades quickly }\end{array}$ & $\begin{array}{l}\text { Deposits and filter } \\
\text { plugging, settling of } \\
\text { solids, corrosive to } \\
\text { aluminum and mild } \\
\text { steel }\end{array}$ & \begin{tabular}{|l|} 
Amount of \\
stabilization required \\
to allow shipping as or \\
with crude oil, study \\
of stabilization \\
methods \\
\end{tabular} & $\begin{array}{l}\text { Probably lower than } \\
\text { crude oil, but also } \\
\text { lower fuel value and } \\
\text { requires both } \\
\text { stabilization and } \\
\text { refining } \\
\end{array}$ & $\begin{array}{c}22,35,44 \\
49,119 \\
129,140\end{array}$ \\
\hline Syngas & $\begin{array}{l}\text { Biocrude, refiner } \\
\text { feedstock }\end{array}$ & \begin{tabular}{|l|} 
Can be derived from \\
biomass, provides $\mathrm{CO}$ and \\
$\mathrm{H} 2$ for refinery applications
\end{tabular} & $\begin{array}{l}\text { Also contains } \mathrm{CO} 2, \mathrm{H} 2 \mathrm{O} \\
\text { and other impurities, } \\
\text { unless purified }\end{array}$ & $\begin{array}{l}\text { Currently no } \\
\text { infrastructure for } \\
\text { shipping, generated at } \\
\text { point of use }\end{array}$ & $\begin{array}{l}\text { CO is highly toxic, } \\
\text { syngas very } \\
\text { flammable }\end{array}$ & $\begin{array}{l}\text { Can be corrosive } \\
\text { depending on } \\
\text { impurities and } \\
\text { presence of water, } \\
\text { hydrogen difficult to } \\
\text { seal and contain }\end{array}$ & $\begin{array}{l}\text { Generation, } \\
\text { distribution, and use of } \\
\text { support liquid motor- } \\
\text { fuel market }\end{array}$ & \begin{tabular}{|l|} 
Depends on \\
feedstock, process, \\
and amount of \\
purification needed
\end{tabular} & $\begin{array}{c}16,58,59 \\
64,84,100, \\
111\end{array}$ \\
\hline
\end{tabular}


each of these fuels and identifies gaps in this knowledge. Since many of these fuels are just emerging or considered future options, identification of knowledge gaps could be important in planning future research and development activities. Each of the fuels listed in Table 5 is discussed here in greater detail to highlight possible issues or problems with each of them.

\subsection{DIESEL-LIKE FUELS}

FAME is used extensively as a diesel supplement due to its similarity to diesel both physically and chemically and due to its ability to be blended with diesel in any combination. Three major issues facing FAME biodiesel distribution are a higher cloud point than diesel, lower stability, and the cleaning effect. The higher cloud point may necessitate the use of heating or insulation along the distribution channels in colder climates to prevent separation from the diesel mixture and to minimize pumping work. Stability can lead to filter plugging issues, especially in cold weather, but can be largely controlled by additives. The cleaning effect, whereby accumulated sediments dissolve into the FAME, increasing the likelihood of filter plugging and injector deposits, necessitates proper washout of pipes and vessels and removal of all residual water and dirt. In addition, batch sequencing in the pipeline becomes an important issue due to the potential of FAME contamination of jet fuel. The polarity resulting from the high oxygen content in FAME can cause it to cling to pipe and vessel walls, making contamination of subsequent batches more likely. These issues have led most large U.S. pipeline operators to expressly prohibit FAME in pipelines. However, as discussed previously, a notable exception to this is Kinder Morgan.

Green diesel's major advantage over FAME is the deoxygenation that occurs during processing, so that green diesel does not display a cleaning effect and should exhibit improved storage stability. It also has a comparable cloud point to diesel, making it compatible with the existing oil pipeline in the opinions of several of its current producers. This potential, coupled with the current lack of extensive research on its compatibility and fungibility, makes green diesel a good candidate for future study.

Similarly, Fischer-Tropsch (F-T) diesel has the advantage of being non-oxygenated with a comparable cloud point to diesel. Many of its current producers also claim that it is compatible with the existing oil pipeline, necessitating further research into this fuel. It can be derived from gasified biomass, although most F-T fuel currently manufactured is derived from natural gas or coal.

Algae-derived FAME, derived from converting oils or fats extracted from algae to FAME, can be rich in unsaturated fats, leading to oxidation susceptibility. For this reason, algae biodiesel does not currently comply with the biodiesel regulations of the European Union. It also has a higher viscosity than diesel, which could result in additional pumping work to move it through a pipeline. Little information is available, since commercial production is limited and further research is needed.

\subsection{GASOLINE-LIKE FUELS}

Ethanol is extensively distributed and utilized as a fuel blend component throughout the United States. Its low freezing point makes it suitable for use in cold climates, it can be blended with gasoline in any combination, and it is currently approved as a $10 \%$ blend for all vehicles and as an $85 \%$ blend for flexfuel vehicles. There are, however, several distribution-related challenges associated with ethanol. It is completely miscible with water and will separate from a gasoline mixture if enough water is present either in the pipeline or as water bottoms in a storage tank. Similarly to FAME, it also displays a cleaning effect, necessitating washout before utilizing ethanol. Additionally, numerous studies have cited ethanol's role in corrosion or stress corrosion cracking of pipeline walls. All of these challenges have led to many major U.S. pipeline operators expressly prohibiting ethanol and ethanol-gasoline mixtures in the pipeline. As discussed previously, Kinder Morgan is allowing the shipment of neat ethanol on one pipeline. 
As with ethanol, butanol is also an oxygenated fuel that can be blended with gasoline in any combination and requires only minor modifications for use in existing vehicles. This fuel's producers also claim that butanol is compatible with the existing oil pipeline infrastructure, but these claims have yet to be verified. Further research into butanol is warranted. Butanol has four isomers (molecular arrangements), and there is little existing data regarding optimization of these isomers from either a manufacturing or fuel performance standpoint.

Both green gasoline and Fischer-Tropsch gasoline have thus far been the subject of very little published research. Initial studies indicate that the latter could potentially exhibit physical and chemical properties similar to those of gasoline.

\subsection{BIOCRUDES AND REFINERY INTERMEDIATES}

Pyrolysis oil is a promising biocrude, but there are several significant issues associated with its distribution in and compatibility with the crude pipeline infrastructure. It can have a very high oxygen and water content, which must be removed, it is highly corrosive, and it is chemically unstable due to the high char and solids content. Suspended char particles can also contribute to phase separation. In addition, its alkali metals content can lead to deposits in filters, boilers, etc. and can contribute to catalyst poisoning. The higher viscosity of pyrolysis oil compared to petroleum crude necessitates increased pumping work. The high oxygen content contributes to its polarity, causing pyrolysis oil residue to cling to pipe and vessel walls. It is likely that pyrolysis oil will need some intermediate upgrade step before it can be shipped long distances to an oil refinery for further processing.

Syngas derived from biomass is a gas at ambient conditions composed mainly of $\mathrm{CO}$ and $\mathrm{H}_{2}$. Syngas is normally used as a feed to the manufacture of F-T fuels and can also be used as a fuel to supply heat in refining operations. The hydrogen is also useful for hydrotreating operations, necessary to upgrade fuels and to remove impurities. It would require a distribution infrastructure similar to that required by natural gas if shipped long distances. Syngas can promote corrosion if exposed to water. The hydrogen component is prone to leaks and the carbon monoxide component is highly toxic. This would necessitate additional modifications and maintenance in order to prevent syngas leaks.

One potential hurdle to the future utilization of biocrudes is the RFS2 legislation concerning co-processing. If a biocrude is co-processed with petroleum crude and the resulting mixture is refined to produce a dieselbiodiesel mixture, this fuel will not qualify as a biomass-based diesel fuel. Biomass-based diesel fuels can be blended with petroleum diesel, but they cannot, by RFS2 definition, be the product of co-processing operations. If the appropriate greenhouse gas emissions requirements are met, the resulting fuel would qualify as an advanced biofuel or cellulosic biofuel. This could potentially hinder the flexibility of the biocrude medium, specifically as it pertains to biodiesel production and distribution.

\subsection{SHIPPING PYROLYSIS OIL AS CRUDE OIL OR CO-MINGLED WITH CRUDE}

Crude oil is gathered from production fields and then consolidated and shipped through a large series of dedicated pipelines in the United States and Canada between production locations, shipping and receiving locations, storage facilities, and petroleum refineries. In this section, we provide a preliminary comparison of crude oil requirements and typical pyrolysis properties and chemistry, with the recommendation that this area of study be revisited next year. Crude oil is shipped as segregated batches, and the concept of fungibility has not been applied to these shipments. No doubt, trading of crude does take place, but controlled by the individual parties involved rather than by commonly accepted fungibility specifications such as those applied to finished petroleum products. Pipeline requirements for crude oil are designed to allow a given system to operate safely, in compliance with various laws, and within its engineering design capabilities. 
The information discussed in this section was obtained from the Sunoco Pipeline L.P. website [168], www.sunocologistics.com. Five documents were selected to be representative of typical crude oil shipping requirements: Sunoco Pipeline L.P. Rules and Regulations Governing the Transportation of Crude Petroleum, Texas R.R.C. No. 11 and F.E.R.C. No. 3, Sunoco Pipeline L.P. Local Proportional Pipeline Tariff, Texas R.R.C. No. 11 and F.E.R.C. No. 142, and Sunoco Pipeline L.P. Viscosity Table. These references do not represent universal pipeline requirements for crude oil but are used to provide a comparison between typical crude oil and typical pyrolysis oil.

Crude oil varies greatly worldwide and is mainly described by three properties - density, percent sulfur, and viscosity - with these properties showing only limited correlation to each other. A summary of 98 crudes shown on the Sunoco Pipeline L.P. website indicates density ranging from 0.73 to 0.93 specific gravity or 21 to 61 API gravity (an inverse scale), sulfur ranging from 0.02 to $3.8 \%$, and viscosity ranging from 2.7 to 1541 SUS at $60^{\circ} \mathrm{F}$ and averaging 163 SUS. Typically, crude with sulfur less than $0.5 \%$ is called sweet, and with sulfur greater than $0.5 \%$, sour. Crude with a density of less than $0.87 \mathrm{~kg} / \mathrm{m}^{3}$ is called light; 0.87 to 0.92 , medium; 0.92 to 1.00 , heavy; and greater than 1.00 , extra heavy.

Since crude oil is normally shipped in segregated batches, details of properties and chemistry are of interest to the pipeline company only to the extent that they affect operations or other batches of crude being shipped. Crude oil (direct liquid products) can be co-mingled with other products at point of origin or other reception points, such as gas condensate or other hydrocarbons (indirect liquid products), providing that the shipper, consignee, and destination are the same and that material entering the pipeline system meets appropriate specifications and requirements. Specifications for crude and mixtures of crude oil and other products that must be met for material to be accepted for shipment are shown in Table 6 . These specifications were set assuming that the majority of materials shipped as crude oil would be, in fact, crude or condensate from natural gas collection wells. As such, they would probably require further definition if something as different as pyrolysis oil was shipped as crude oil or blended with crude oil. As a market develops, requirements will probably be revised and further defined to reflect operating experience and market demand.

A comparison between the crude requirements in Table 6 and the pyrolysis oil properties in the exhibits reveals a large discrepancy between pyrolysis oils and crude oil. Pyrolysis oil is not soluble in hydrocarbons but is soluble in water and alcohols. It contains both large amounts of water and chemically bound oxygen and smaller amounts of nitrogen. It can contain large amounts of carbon and smaller amounts of residual agricultural minerals (sodium, potassium, calcium, magnesium). Pyrolysis oil is denser than crude oil, can have high viscosity, and contains less carbon and hydrogen than crude oil with corresponding lower energy content. The upgrading of pyrolysis oil to match crude requirements for shipment appears to be extensive, and it is unclear if this would be economically and technically feasible. Other options for pyrolysis oil would be to use as fuel for boilers, turbines, or large, slow-speed engines, all of which may be more accepting of lower grade fuels or mixing of lower grade with current grade fuels. Residual metals in the pyrolysis oil ( $\mathrm{Na}, \mathrm{K}, \mathrm{Ca}, \mathrm{Mg}$ ) may also prove difficult to remove and could act as poisons for upgrading catalysts and for emissions control catalysts when upgraded pyrolysis oil is burned as a fuel. The authors of this report recommend further study of the upgrade options for pyrolysis oil and further study of the compatibility of its use as a refinery feed to supplement crude oil. 
Table 6. Representative crude requirements for pipeline shipments [168]

\begin{tabular}{|c|c|c|}
\hline Property & Limit per Texas R.R.C. No. 11 and 40 & Limit per F.E.R.C. No. 3 and 142 \\
\hline Vapor pressure, petroleum & 9 psi summer, 10.7 psi winter $@ 100^{\circ} \mathrm{F}$ & 12 psi at $100^{\circ} \mathrm{F}$ \\
\hline $\begin{array}{l}\text { Vapor pressure, condensate or } \\
\text { other indirect product }\end{array}$ & $11.5 \mathrm{psi}$ summer, $13.7 \mathrm{psi}$ winter at $100^{\circ} \mathrm{F}$ & 12 psi at $100^{\circ} \mathrm{F}$ \\
\hline Proportion of indirect product & $<20 \%$ & \\
\hline Vapor pressure & $\begin{array}{l}\text { In compliance with all federal, state, and } \\
\text { local requirements }\end{array}$ & $\begin{array}{l}\text { In compliance with all federal, state, } \\
\text { and local requirements }\end{array}$ \\
\hline API gravity & 20 to 65 & 20 to 120 \\
\hline Evaporative loss correction & $0.2 \%$ for API gravity below 50 & \\
\hline Foreign sediment and water & $<2 \%$ & $<1 \%$ with $<0.3 \%$ water \\
\hline Contamination & Incrustation of tanks $\mathrm{n}$ ot excessive & Incrustation of tanks not excessive \\
\hline Contamination & $\begin{array}{l}\text { Sediment in tanks } 4 \text { in. below bottom of } \\
\text { pipeline connection }\end{array}$ & $\begin{array}{l}\text { Sediment in tanks } 4 \text { in. below bottom } \\
\text { of pipeline connection }\end{array}$ \\
\hline Contamination & Iron $<75 \mathrm{ppm}$ & \\
\hline Contamination & Lead $<0.05 \mathrm{ppm}$ in naphtha fraction & \\
\hline Contamination & Organic chlorides $<5 \mathrm{ppm}$ & \\
\hline Contamination & $\begin{array}{l}\text { Excessive metals, chemicals, salts, } \\
\text { refinery or process plant by-product }\end{array}$ & \\
\hline Temperature & $<120^{\circ} \mathrm{F}$ & \\
\hline Viscosity & $\begin{array}{l}\text { Additional tariff charged when viscosity } \\
\text { exceeds } 150 \text { SUS at } 100^{\circ} \mathrm{F} \text {, up to } 118 \% \text { of } \\
\text { base tariff }\end{array}$ & $\begin{array}{l}\text { Additional tariff charged when } \\
\text { viscosity exceeds } 110 \mathrm{SUS} \text { at } 60^{\circ} \mathrm{F} \text {, } \\
\text { up to } 30 \% \text { of base tariff }\end{array}$ \\
\hline Viscosity & $<250 \mathrm{SUS}$ at $100^{\circ} \mathrm{F}$ & $\begin{array}{l}<300 \text { SUS at } 60^{\circ} \mathrm{F},>200 \mathrm{SUS} \text { not } \\
\text { accepted if degrades pipelline } \\
\text { capacity }\end{array}$ \\
\hline Additives & $\begin{array}{l}\text { Carrier reserves right to inject or to } \\
\text { approve injection of corrosion inhibitors } \\
\text { or drag reducing agens }\end{array}$ & $\begin{array}{l}\text { Carrier reserves right to inject or to } \\
\text { approve injection of corrosion } \\
\text { inhibitors }\end{array}$ \\
\hline
\end{tabular}

\section{A MARKET FOR BIO-DERIVED HYDROCARBONS}

Today's fuels are blended from a number of refinery intermediate streams (about five to seven for gasoline and three to five for distillate fuels). The resulting finished fuels contain a large number of compounds with various molecular weights. Overall, gasoline contains about 300 individual compounds, and distillate fuels, about 2500. The use of multiple processing options and resulting blending streams allows maximum utilization of crude oil and multiple options for blending to allow for refinery optimization. Some molecules are desirable for building required properties or meeting specifications, some are more neutral in effect but expand fuel volumes in a cost-effective manner, and some are undesirable in certain products but may be helpful in others.

With biofuels, it may not be economical to supply the entire range of property and specification requirements of today's petroleum fuels, and it may be more efficient if bio-derived materials are used as blending streams along with petroleum-derived components for fuel blending. Overall, bio-derived blending streams can be utilized via three paths to market: (1)They can be manufactured and used within a specific refinery fuel blending operation. (2) The biofuel blend streams could be transported to a specific refinery or blending site by proprietary or common carrier pipeline or other means such as truck or barge for private sale to an energy company. Finally, (3) certain biofuel blending streams can be sold or traded on the open market. 
Platts (www.platts.com), in their Refiner newsletter [169], lists pricing for the blendstocks and intermediate refinery components, and their website also lists partial specifications. Prices are shown for April 3, 2009, and change daily (this date was chosen because it happened to be the date of a sample newsletter that could be freely downloaded). These materials are typically traded in volume increments of 50,000 barrels. Table 7 provides specifications, use, and representative pricing for commonly traded blending streams and refinery intermediates. The table shows product information listed in the newsletter. When batches of these products are actually traded, a full analysis is normally required.

The properties of the more highly valued streams could be targeted for biofuel manufacturing and would consist of mixed, longer chain paraffins for distillate blending and aromatics and isoparaffins for gasoline blending. 
Table 7. Commonly traded fuel blending streams and refinery intermediates ${ }^{a}[169]$

\begin{tabular}{|c|c|c|c|c|c|c|c|c|c|c|}
\hline Product & Chemistry & Use & Pricing & $\begin{array}{c}\text { Sulfur, max } \\
(\%)\end{array}$ & $\begin{array}{c}\text { API } \\
\text { gravity }\end{array}$ & $\begin{array}{l}\text { RVP } \\
\text { (psi) }\end{array}$ & $\begin{array}{l}\mathrm{R}+\mathrm{M} / 2 \\
\text { octane }\end{array}$ & RON & $\begin{array}{c}\mathrm{N}+\mathrm{A}, \text { min } \\
(\%)\end{array}$ & $\begin{array}{l}\text { P, min } \\
(\%)\end{array}$ \\
\hline Alkylate & $\begin{array}{l}\text { C5 to } \mathrm{C} 8 \\
\text { isoparaffins }\end{array}$ & Gasoline blending & $\begin{array}{l}\text { Gasoline }+ \\
\$ 0.20\end{array}$ & & & 5.5 & $92-93$ & & & \\
\hline Reformate & $\begin{array}{l}\text { Mixed aromatic, } \\
\text { isoparaffin, and }\end{array}$ & Gasoline blending & $\begin{array}{l}\text { Gasoline + } \\
\$ 0.46\end{array}$ & 0.5 & $30-55$ & $0.5-2.5$ & & $95-100$ & & \\
\hline Raffinate & $\begin{array}{l}\text { Reformate with } \\
\text { BTX removed }\end{array}$ & Gasoline blending & $\begin{array}{l}\text { Gasoline - } \\
\$ 0.08 \\
\end{array}$ & 0.5 & $60-70$ & $2.0-6.0$ & & $55-65$ & & \\
\hline Xylene & Pure aromatic & $\begin{array}{l}\text { Gasoline blending } \\
\text { or petrochemical }\end{array}$ & $\$ 2.10$ & & & & & & & \\
\hline Toluene & Pure aromatic & $\begin{array}{l}\text { Gasoline blending } \\
\text { or petrochemical }\end{array}$ & $\$ 1.85$ & & & & & & & \\
\hline $\begin{array}{l}\text { Low sulfur straight } \\
\text { run }\end{array}$ & Mixed paraffinic & $\begin{array}{l}\text { Distillate blending } \\
\text { or cat cracker feed }\end{array}$ & \$1.24/gallon & 0.3 & $20-22$ & & & & & \\
\hline Standard naphtha & Mixed paraffinic & Reforming feed & $\$ 1.25$ & & $56-60$ & & & & 40 & \\
\hline Paraffinic naphtha & Mixed paraffinic & Gasoline blending & $\$ 407 / \mathrm{mt}$ & $500 \mathrm{ppm}$ & $65 \max$ & $\begin{array}{l}12.5 \\
\max \end{array}$ & & & & 65 \\
\hline Heavy naphtha & Mixed paraffinic & Reforming feed & $\$ 1.25$ & & 56 & & & & 40 & \\
\hline
\end{tabular}

${ }^{a}$ This table shows information listed in Platts' Refiner newsletter defining general characteristics of these products. When batches are actually traded, a full analysis is required. 


\section{ENTRY POINTS FOR BIO-DERIVED PRODUCTS INTO FUEL INFRASTRUCTURE}

Bio-derived fuels or intermediates could enter the existing refining and distribution infrastructure based on their properties and composition. Table 8 indicates entry points for bio-products of various properties and composition. These possibilities are based on current refining, blending, and distribution practices and would be expected to evolve in the future.

Table 8. Possible entry points for bio-derived materials into petroleum fuel infrastructure

\begin{tabular}{|c|c|c|c|c|c|}
\hline Entry point & Oxygenated feed & $\begin{array}{c}\text { Deoxygenated, } \\
\text { partially refined } \\
\text { feed }\end{array}$ & $\begin{array}{c}\text { Oxygenated } \\
\text { blending } \\
\text { component }\end{array}$ & $\begin{array}{c}\text { Hydrocarbon } \\
\text { blending } \\
\text { component }\end{array}$ & $\begin{array}{c}\text { Finished } \\
\text { fuel }\end{array}$ \\
\hline Refinery feed & $\begin{array}{c}\text { Yes, but oxygen may } \\
\text { limit feed percentage } \\
\text { or require } \\
\text { preprocessing }\end{array}$ & $\begin{array}{c}\text { Yes, but must } \\
\text { resemble refinery } \\
\text { unit feed }\end{array}$ & NO & NO \\
\hline $\begin{array}{c}\text { Refinery blending } \\
\text { operation }\end{array}$ & NO & $\begin{array}{c}\text { Yes, but must be } \\
\text { similar to current } \\
\text { blend streams }\end{array}$ & NO & YES & YES \\
\hline Terminal & NO & NO & $\begin{array}{c}\text { Yes, but must meet } \\
\text { ethanol or FAME } \\
\text { specifications }\end{array}$ & NO & YES \\
\hline
\end{tabular}

\section{COST ESTIMATES FOR BIO-DERIVED FUELS}

Table 9 summarizes the cost data for several biofuels production facilities. More detailed cost information can be found in the exhibits. The table displays examples of biofuel manufacturing plants and shows annual volume of biofuel produced, capital and operating costs, and feedstock cost.

It should be noted that there is a large variation in capital costs, ranging from roughly $\$ 6.6$ million for a 4 million gallon/year (MMGPY) FAME facility to \$341 million for a 35 MMGPY F-T diesel facility. Cellulosic ethanol and F-T diesel facilities appear to require significantly larger capital investment than do grain ethanol, FAME, and pyrolysis oil facilities. This may be partially attributable to the fact that the latter three are preexisting technologies that have been studied and iterated extensively, whereas the former two are relatively new and less researched technologies. If examined on a volume basis, the operating costs for all facilities also differ.

Both Table 9 and the exhibits clearly demonstrate that feedstock cost is by far the most significant component of operating costs - for example, amounting to $80 \%$ of total operating costs in the FAME facility study. Feedstock costs are also volatile, and small shifts in price can translate into substantial shifts in operating costs for a biofuel producer. This subsection is not intended to provide set price guidelines for building, operating, and maintaining a biofuels production facility but, rather, to provide a relative comparison between the current prices of various biofuels. 
Table 9. Summary of capital and operating costs for several biofuels facilities

\begin{tabular}{|c|c|c|c|c|c|c|c|}
\hline Product & $\begin{array}{c}\text { Volume } \\
\text { (million } \\
\text { gallons/year) }\end{array}$ & $\begin{array}{c}\text { Volume } \\
\text { (barrels/ } \\
\text { day) }\end{array}$ & $\begin{array}{c}\text { Capital } \\
\text { costs } \\
\text { (\$ million) }\end{array}$ & $\begin{array}{c}\text { Yearly } \\
\text { operating } \\
\text { costs } \\
\text { (\$ million) }\end{array}$ & Feed & Feed costs & $\begin{array}{c}\text { Operating } \\
\text { +feed costs } \\
\text { (\$/gallon) }\end{array}$ \\
\hline $\begin{array}{c}\text { Pyrolysis oil } \\
{[94,111,132,} \\
164]\end{array}$ & 30 & 1950 & 48 & 9.6 & Wood chips & $\begin{array}{c}\$ 30 \text { per dry } \\
\text { ton }\end{array}$ & 0.32 \\
\hline $\begin{array}{c}\text { Ethanol } \\
{[11,163]}\end{array}$ & 25 & 1630 & 27.9 & 22 & Grain & & 0.88 \\
\hline $\begin{array}{c}\text { Ethanol } \\
{[11,163]}\end{array}$ & 50 & 3260 & 294 & 76 & Cellulosic & & 1.52 \\
\hline $\begin{array}{c}\text { Methanol } \\
{[163]}\end{array}$ & 87 & 5675 & 254 & 56.5 & $\begin{array}{c}\text { Biomass } \\
\text { syngas }\end{array}$ & & 0.65 \\
\hline $\begin{array}{c}\text { F-T diesel } \\
{[111,147,} \\
163]\end{array}$ & 35 & 2283 & 341 & 87.5 & $\begin{array}{c}\text { Biomass } \\
\text { syngas }\end{array}$ & & 2.50 \\
\hline $\begin{array}{c}\text { FAME } \\
{[38,69]}\end{array}$ & 4 & 260 & 6.6 & 8 & $\begin{array}{c}\text { Yellow } \\
\text { grease }\end{array}$ & $\$ 0.17$ per lb & 2.00 \\
\hline $\begin{array}{c}\text { FAME } \\
{[38,69]}\end{array}$ & 4 & 260 & 6.6 & 12.5 & Soy oil & $\$ 0.31$ per lb & 3.13 \\
\hline $\begin{array}{c}\text { FAME } \\
{[38,69]}\end{array}$ & 10 & 650 & 8.8 & 18 & $\begin{array}{c}\text { Yellow } \\
\text { grease }\end{array}$ & $\$ 0.17$ per lb & 1.80 \\
\hline $\begin{array}{c}\text { FAME } \\
{[38,69]}\end{array}$ & 10 & 650 & 8.8 & 29.2 & Soy oil & $\$ 0.31$ per lb & 2.97 \\
\hline
\end{tabular}

Limited cost data analysis references were available, and much of the data is unconfirmed by multiple sources. Specific capital, operating, and feedstock costs are thus associated with specific studies and may not necessarily be applied as general cost guidelines for all biofuels production facilities.

Some of the studies used for cost estimates examine several different types of biofuels facilities, such as one study that examined F-T diesel, ethanol, and pyrolysis oil, and another that examined F-T diesel, ethanol, and methanol. Most, however, specialize in one particular type of biofuel. Each study has a specific set of methods employed in its cost data analysis which result in capital and operating cost conclusions that are not necessarily directly comparable. The operating cost figure in the FAME study, for example, includes profits gained by selling the by-product glycerin at $\$ 0.26$ per pound. One of the pyrolysis oil studies applies its analysis for the $n^{\text {th }}$ number facility, as opposed to a pioneer plant, while others are not specific as to which facility is being studied. As was stated earlier, this subsection is not meant to provide price guidelines for building and operating a biofuels production facility but, rather, to provide a relative comparison between the projected prices of biofuels production and how this, along with numerous other factors, might determine the extent of their role in the U.S. biofuels portfolio.

\section{CONCLUSIONS AND RECOMMENDATIONS}

The expansion and further development of the biofuels industry will require that a number of decisions and investments be made. It is likely that ethanol will remain a major renewable fuel component and will continue to be terminal blended, with manufacturing of ethanol separate from oil refineries and with separate transportation to the blend site. Although EPA no longer requires oxygen in reformulated gasoline for nonattainment areas (Federal Register, May 8, 2006 [Vol. 71, No. 88, Rules and Regulations, 
pp. 26691-26702]), its use as a renewable fuel component is likely to continue and grow due to existing capacity, familiarity, financial incentives or tax breaks, and requirements of state or federal laws related to pollution reduction, farm support, or renewable content. It is technically possible that ethanol could be refinery blended and shipped over pipelines, but the economic benefits of doing this would depend on where ethanol is manufactured and used, form of transportation available, and pipeline capacity to handle the resulting larger gasoline/ethanol volumes. It would also require continued removal and monitoring of water in the distribution system and further study of the potential issues of ethanol-induced rust, corrosion, or stress corrosion cracking in distribution equipment. Elastomeric gaskets, seals, and piping would also have to be proven or changed to be compatible with ethanol fuels, but this is not expected to be a major roadblock.

Oils, fats, and greases are normally converted to fatty acid methyl esters or FAME, which is the most common form of biodiesel. FAME and FAME blends with diesel fuel are polar and therefore subject to water contamination, can contaminate other fuels shipped after biodiesel, can have a cleaning effect, and can have cold flow, filtration, or long-term stability problems. FAME quality issues were probably more frequent during the development of the industry and start-up of new manufacturing plants and have been largely eliminated with ASTM specifications covering both B100 and blends, with more manufacturing and distribution experience, and with the use of stability and filtration additives. FAME is normally added at a product terminal during truck loading, using on-line rack blending similar to that used for ethanol. This practice keeps the B100 FAME segregated from other products and results in the faster turnover of product. Production of FAME will likely increase in the future, due to the use of palm oil, increased use of waste oils and fats, and because of the algae potential for manufacturing fats and oils from $\mathrm{CO}_{2}$ and water. There is limited experience with the shipping of FAME biodiesel over pipelines, and it appears to be successful. This experience is with pipelines that do not also ship jet fuel, but there is ongoing work relative to contamination and detection of contamination of jet fuel with FAME which may help support more flexible shipping practices in the future.

Currently, ethanol and FAME are largely manufactured from purpose-grown crops, with starch and sugar plants being used to supply ethanol fermentation and oil plants being used to supply oil and fats for FAME production. An emerging method for biofuel production is from gasified or pyrolyzed biomass on a large scale. Gasification results in $\mathrm{CO}$ and $\mathrm{H}_{2}$, which can be recombined to liquid hydrocarbons using Fischer-Tropsch processing. Pyrolysis results in a liquid known as pyrolysis oil, which could be considered as a bio-derived crude oil. Unfortunately, such pyrolysis oil is heavily contaminated by residual plant compounds, has a very high oxygen and water content, has a high total acid number and corresponding low $\mathrm{pH}$, and is relatively unstable. This could be an important source of fuel, providing these problems can be overcome economically. Pyrolysis oil could be upgraded in several steps: In the first step, it could be upgraded sufficiently to allow it to be shipped in a manner similar to crude oil; in the second step, it could be upgraded sufficiently to be used as a refinery unit feed; in the third step, it could be refined sufficiently to be used directly as a fuel blending component with petroleum-derived blending streams; and in the fourth step, it could be refined sufficiently to act as a final fuel and direct substitution for diesel fuel or gasoline. The authors speculate that the easiest entry point into existing infrastructure would be to upgrade sufficiently to allow the shipping of pyrolysis oil in a similar manner to crude oil, which would allow entry to the refining, blending, and distribution infrastructure already in use for petroleum-derived fuels. The options for this level of upgrading and the degree of upgrading required are recommended as a topic for additional study.

In addition to producing ethanol by fermentation of sugar, starch, or cellulose, or the conversion of oils and fats to FAME, these materials can also be converted to other hydrocarbon components using catalytic (refining-like) processes. There are many options - some are under current investigation, some may already be in use for fuel manufacturing or for making other industrial chemicals, and some have been discussed but not experimentally investigated. Further study of the processes and information available 
about each process is recommended. Overall, the recommendations for further study are summarized in Table 10. These tasks have been used to form a basis for discussions related to continuing this research.

Table 10. Recommendations for further study

\begin{tabular}{|c|c|c|l|}
\hline $\begin{array}{c}\text { Recommendation } \\
\text { number }\end{array}$ & Feed material & Fuel & Recommended areas for future investigation \\
\hline 1 & $\begin{array}{c}\text { Sugar, starch, } \\
\text { cellulose }\end{array}$ & Ethanol & $\begin{array}{l}\text { Study of rust, corrosion, and stress corrosion } \\
\text { cracking of mild and low alloy steel by ethanol } \\
\text { and ethanol containing fuels and related } \\
\text { industrial experience }\end{array}$ \\
\hline 2 & $\begin{array}{c}\text { Sugar, starch, } \\
\text { cellulose }\end{array}$ & Ethanol & $\begin{array}{l}\text { Study of control and removal of water bottoms } \\
\text { from fuel distribution system and related } \\
\text { industrial experience }\end{array}$ \\
\hline 3 & Fats, oils & FAME biodiesel & $\begin{array}{l}\text { Study of issues associated with shipping } \\
\text { FAME biodiesel over common carrier } \\
\text { distribution system, including batch sequencing } \\
\text { with and possible contamination of jet fuel, } \\
\text { and related industrial experience }\end{array}$ \\
\hline 4 & Biomass & Pyrolysis oil & $\begin{array}{l}\text { Study of the issues, options, and degree of } \\
\text { upgrading required to allow pyrolysis oil to be } \\
\text { treated like crude oil for shipping purposes }\end{array}$ \\
\hline 5 & $\begin{array}{c}\text { Sugars, starch, oils, } \\
\text { fats }\end{array}$ & $\begin{array}{c}\text { Hydrocarbon fuel } \\
\text { blending components }\end{array}$ & $\begin{array}{l}\text { Study of the options and current state of } \\
\text { knowledge relative to converting biofeeds to } \\
\text { fuel compatible hydrocarbons }\end{array}$ \\
\hline
\end{tabular}

\section{REVIEW OF COMMENTS RECEIVED AND SUGGESTED MODIFICATIONS OR ADDITIONS FOR FUTURE STUDY}

This report, in draft form, was distributed to four integrated oil companies, two of which provided comments with the understanding that the comments do not represent official company views and would not be attributed to the companies or individuals. DOE also provided guidance and comments relative to priorities for a possible continuation of this research. All of these comments have been combined in this section, without attribution, as possible technical recommendations for future work. We note that many of these recommendations are beyond the scope of the current study and have been or are being addressed in other studies. They are listed here for completeness and to help provide guidance for this and other projects.

1. Suggestion was made to de-emphasize study of ethanol-related infrastructure issues, since ethanol has already been and is being heavily studied in other projects. (These are topics 1 and 2 in Table 10.)

2. Provide more information or recommendations related to health effects of new biofuels with discussion related to the amount or type information that might be required for EPA approval of these new fuels. (This would be a new addition to Table 10.)

3. Extend infrastructure compatibility evaluation to include service stations, current vehicles, and future vehicles. Provide survey of types of materials in current use and industry plans for material changes or upgrading. Provide summary of approvals necessary for fueling equipment. (This would be a new addition to Table 10.) 
4. Discuss in more detail how oxygen in fuels affects engine operation and infrastructure compatibility. Discuss changes that could mitigate these effects. (This would be a new addition to Table 10.)

5. Expand study of pyrolysis oils in the areas of chemistry, properties, and material compatibility. (This is an expansion of topic 4 in Table 10.)

6. Topics 3 and 5 in Table 10 should remain as written.

7. Review and coordinate research with other labs or companies working on infrastructure-related issues in order to disseminate results, gather information, build synergy, and avoid duplication.

\section{REFERENCES}

The following list of references was compiled during preparation of the exhibits at the end of this report. The fuel or information about which the reference pertains is given at the end of each reference.

Acros Organics, "1-Butanol Material Data Safety Sheet," www.acros.com, December 2009 - 1-Butanol compatibility.

Adu-Gyamfi, Villa, Coulon, "Renewable Energy, Landfill Gas and EfW: Now, Next and Future," http://www.geotech.co.uk/press_releases/Geotech\%20sponsored\%20paper.pdf - Methane partial properties.

Aguayo, Gayubo, Tarrio, Atutxa, Bilbao, "Study of Operating Variables in the Transformation of Aqueous Ethanol into Hydrocarbons on a HZSM-5 Zeolite," Journal of Chemical Technology and Biotechnology 77, 211-216 (2002) - Sugars and alcohols information.

Air Liquide, "1-Propanol MSDS,” http://www.scottecatalog.com/msds.nsf/MSDSNo/71-23-8 1-Propanol partial properties.

Air Products and Chemicals for DOE, Alternative Fuels and Chemicals from Synthesis Gas, Quarterly Report Jan. 1-Mar. 31, 1998 - Glyme information.

Alasfour, Butanol, "A Single Cylinder Engine Study: Engine Performance," International Journal of Energy Research 21, 21-30 (1997) - Butanol partial properties.

Alleman, McCormick, Fischer-Tropsch Diesel Fuels-Properties and Exhaust Emissions: A Literature Review, SAE Technical Paper 2003-01-0763 - FT diesel partial properties.

Alvarado, Peter J., "Steel vs. Plastics: The Competition for Light-Vehicle Fuel Tanks," JOM 48(7), 22-25 (1996) - Vehicle materials.

Amerada Hess Corporation, Methyl tert-Butyl Ether (MTBE), Material Safety Data Sheet No. 9922, April 1998 - MTBE partial properties.

American Chemical Society, Organic Chemistry Division, "Common Organic Solvents-Table of Properties," http://organicdivision.org/organic_solvents.html - Butanol partial properties.

Anex, Aden, Kazi, Fortman, Swanson, Wright, Satrio, Brown, Daugaard, Platon, Kothandaraman, Hsu, Dutta, "Techno-Economic Comparison of Biomass-to-Transportation Fuels Via Pyrolysis, Gasification, and Biochemical Pathways," accepted to Fuel in February 2010 - Pyrolysis oil, ethanol, and FT production facility costs.

Argonne National Laboratory, "Biobutanol Properties," http://www.greencarcongress.com/2008/08/argonne-investi.html - Biobutanol partial properties. 
Assael, Polimatidou, "Measurements of the Viscosity of Alcohols in the Temperature Range 290-340 K at Pressures up to $30 \mathrm{Mpa,"} \mathrm{International} \mathrm{Journal} \mathrm{of} \mathrm{Thermophysics} \mathrm{15,} \mathrm{95-107} \mathrm{(1994)} \mathrm{-} \mathrm{Methanol}$ partial properties.

Atsumi, S., Hanai, T., Liao, J. C., "Non-fermentative Pathways for Synthesis of Branched-Chain Higher Alcohols as Biofuels," Nature 451 (2008), doi:10.1038/nature06450 - Higher C alcohols information.

Avantec Performance Chemicals, www.inventec.dehon.com, December 2009 - DME compatibility.

Bain, Richard, "An Introduction to Biomass Thermochemical Conversion," DOE/NASLUGC Biomass and Solar Energy Workshops, Aug. 3-4, 2004 - Syngas partial properties.

Bechtold, Richard L., Alternative Fuels Guidebook: Properties, Storage, Dispensing, and Vehicle Facility Modifications, SAE Order Number R-180, 1997 - Gasoline partial properties.

Bedoukian Research Inc, (e)-beta-Farnesene, MSDS P3500-90, http://www.bedoukian.com/products/displayGraphic.asp?type=m\&product=P3500-90, Aug. 3, 2007 Sesquiterpene (farnasene) partial properties.

Bertola, Boulouchos, Oxygenated Fuels for Particulate Emissions Reduction in Heavy-Duty Di-Diesel Engines with Common-Rail Fuel Injection, SAE Technical Paper 2000-01-2885 - Diesel and glyme partial properties and compatibility.

Biofuels Digest, "US Ethanol Production Capacity to Increase to 13.3 Billion Gallons in 2008," www.biofuelsdigest.com, Jan. 9, 2008 - US ethanol production and capacity.

Biofuels Journal, “Annual and Monthly US Ethanol Production,” www.biofuelsjournal.com, Dec. 5, 2006 - U.S. ethanol production and capacity.

Blin, Volle, Girard, Bridgwater, Meier, "Biodegradability of biomass pyrolysis oils: Comparison to conventional petroleum fuels and alternatives fuels in current use," Fuel 86, 2679-2686 (2007) Pyrolysis oils environmental/ compatibility.

Blommel, Cortright, Production of Conventional Liquid Fuels from Sugars, White Paper, Virent Energy Systems, Inc., Aug. 25, 2008 - Sugars and alcohols information.

BOC Gases, "MSDS: Hydrogen," www.fergusongases.com, June 7, 1996 - Hydrogen compatibility.

BP, "Biobutanol Fact Sheet," www.bp.com, 2009 - Biobutanol compatibility.

Buckeye Partners LP, www.buckeye.com, December 2009 - Pipeline map/shipping information.

California Air Resources Board Solvents Database, "Butanol," http://www.arb.ca.gov/db/solvents/solvent_pages/alcohols-html/butanol.htm - Biobutanol partial properties.

California Air Resources Board, "Solvents Database, 1-propanol," http://www.arb.ca.gov/db/solvents/solvent_pages/Alcohols-HTML/propanol.htm - 1-propanol partial properties.

Cameo Chemicals Inc., "Isoprene," www.cameochemicals.noaa.gov, June 1999 - Isoprene compatibility.

Cameo Chemicals, "n-Propanol Chemical Data Sheet," www.cameochemicals.noaa.gov, December 2009 - n-propanol compatibility.

Cardoso, Domingos, Oliveira, Passos, "Chemical Composition and Physical Properties of Black Liquors and Their Effects on Liquor Recovery Operation in Brazilian Pulp Mills," Fuel 88, 756-763 (2009) Lignin liquids partial properties.

Chao, Rossini, "Heats of Combustion, Formation, and Isomerization of Nineteen Alkanols," Journal of Chemical Engineering Data 10, 374-379 (1965) - Propanol and higher C alcohols partial properties.

Chisti, Yusuf, "Biodiesel from Microalgae," Biotechnology Advances 25, 294-306 (2007) - Algae biodiesel compatibility. 
CHOREN Industries, "Biomass-to-Liquid Fuels (BtL)—Made by CHOREN process, Environmental Impact, and Latest Developments," Automobile and Environment at Belgrade EAEC Congress, May 2005 - FT diesel compatibility.

Cirad-Foret, "MSDS: Bio-Oil," May 2006 - Pyrolysis oils compatibility.

CITGO, No. 2 Diesel, MSDS, May 2006, http://www.martineagle.com/MSDS/CitgoLowSulfurDiesel.pdf - Diesel properties.

Colonial Pipeline Co., www.colpipe.com, December 2009 - Pipeline map/shipping information.

Coltrain, David, "Biodiesel: Is It Worth Considering?," Risk and Profit Conference, Kansas State University, August 2002 - FAME production facility costs.

Columbia Engineered Rubber, Inc., www.columbiaerd.com, 2010 - Vehicle materials information.

ConocoPhillips Pipeline LP, www.conocophillipspipeline.com, December 2009 - Pipeline map/shipping information.

Diebold, A Review of the Toxicity of Biomass Pyrolysis Liquids Formed at Low Temperatures, NREL/TP430-22739, National Renewable Energy Laboratory, 1997 - Pyrolysis oils partial properties.

Dominguez, Miguel, Arjona, Millan, "The Effects of Ethanol-Diesel Blended Fuels on the Performance and Emissions of Unmodified Diesel Engines," 14th European Biomass Conference and Exhibition: Biomass for Energy, Industry and Climate Protection, Paris, October 2005 - Ethanol-Diesel blend partial properties.

Dow Chemicals, "Dow n-Propanol Product Safety Assessment," www.dow.com, June 18, 2009 - npropanol compatibility.

Ekbom, T., "High Efficiency Motor Fuel Production from Biomass via Black Liquor Gasification," ISAF XV International Symposium on Alcohol Fuels, September 2005 - Lignin liquids compatibility.

Elliott, Douglas C., Staff Scientist, U.S. Department of Energy, Pacific Northwest National Laboratory, Richland, WA, "Hydroprocessing of Pyrolysis Bio-oil to Fuels and Chemicals," Bioenergy \& Wood Products, Smallwood, May 14, 2008 - Pyrolysis oils partial properties.

Enterprise Products Partners LP, www.epplp.com, December 2009 - Pipeline map/shipping information.

EPUK, "Biogas as a Road Transport Fuel, National Society for Clean Air and Environmental Protection," www.environmentalprotection.org/uk, June 2006 - Methane partial properties and compatibility.

European Biofuels Technology Platform, funded by the EC under Grant Agreement 241269, last updated Feb. 23, 2010, http://www.biofuelstp.eu/hydrogen.html

European Industrial Gases Association, Carbon Monoxide and Syngas Pipeline Systems, IGC Doc. 120/04/E - Syngas partial properties and compatibility.

European Project BioDME, "Production of DME from Biomass and Utilization as Fuel for Transport and for Industrial Use," 7th Framework Program, 2009 - Syngas compatibility.

ExxonMobil Chemical, "Isoprene Product Safety Summary," www.exxonmobilchemical.com, June 2009 - Isoprene compatibility.

ExxonMobil Pipeline Co., www.exxonmobilpipeline.com, December 2009 - Pipeline map/shipping information.

Fanick, "Fuel and Fuel Additive Registration Testing of Ethanol-Diesel Blend for O2Diesel, Inc.," National Renewable Energy Laboratory, www.nrel.gov, February 2004 - Ethanol-diesel blend partial properties.

Farrell, Alexander E., and Sperling, Daniel, “A Low-Carbon Fuel Standard for California,” August 2007 - State policy drivers for increased biofuels usage.

Ferguson, Straub, Richards, Robey, "Impact of Fuel Variability on Dynamic Instabilities in Gas Turbine Combustion," 5th US Combustion Meeting, organized by the Western States Section of the 
Combustion Institute and hosted by the University of San Diego, Mar. 25-28, 2007. - LFG, natural gas, and syngas partial properties.

Ferro Fine Chemicals, "Product Data Sheet, Diglyme," http://www.d-orland.com/pdf/Diglyme.pdf Glyme partial properties.

Fisher Scientific, "MSDS, 3-Methyl-1Butanol," Sept. 30, 2002, https://fscimage.fishersci.com/msds/00798.htm - Higher C alcohols partial properties and compatibility.

Fisher Scientific, "MSDS, DL-2-Methyl-1Butanol, 98\%,"

https://fscimage.fishersci.com/msds/52450.htm, Nov. 20, 2008 - Higher C alcohols partial properties and compatibility.

Fisher, Kein-Marcuschamer, Stephanopoulos, "Selection and Optimization of Microbial Hosts for Biofuels Production," Metabolic Engineering 10, 295-304 (2008) - Terpene information.

Fortenbery, Randall T., "Biodiesel Feasibility Study: An Evaluation of Biodiesel Feasibility in Wisconsin," University of Wisconsin Staff Paper No. 481, March 2005 - FAME production facility costs.

Gautam, Martin, "Combustion Characteristics of Higher Alcohol/Gasoline Blends," Proceedings of the Institution of Mechanical Engineers; Part A; Journal of Power and Energy 214, 497 (2000) Butanol and propanol partial properties.

Georgia Forestry Commission, "Summary of State Incentives and Legislation for Renewable Energy Production," September 2007 - State policy drivers for increased biofuels usage.

Gillette and Kolpa, "Overview of Interstate Hydrogen Pipeline Systems," Argonne National Laboratory, www.corridoreis.anl.gov, November 2007 - Hydrogen compatibility.

Gurbuz, Kunkes, Simonetti, West, Serrano-Ruiz, Gaertner, Dumesic, "Catalytic Production and Upgrading of Biomass Derived Monofunctional Hydrocarbons," Proceedings of the American Institute of Chemical Engineers Annual Meeting, Nashville, TN, November 2009 - Sugars and alcohols information.

Hawkins, Eriksen, "Physical and Thermodynamic Properties of Terpenes. II. The Heats of Combustion of Some Terpene Hydrocarbons," Journal of the American Chemical Society 76, 2669-2671 (1954) Terpene partial properties.

Hawley's Condensed Chemical Dictionary: 11th Ed., 1987 - Methanol compatibility.

Helwani, Othman, Aziz, Fernando, Kim, "Technologies for Production of Biodiesel Focusing on Green Catalytic Techniques: A Review," Fuel Processing Technology, 90, 1502-1514 (2009) - Green diesel information.

Hess, "Material Data Safety Sheet No. 9909, Diesel Fuel," Oct. 18, 2006, http://www.hess.com/ehs/msds/9909DieselFuelAllTypes.pdf - Diesel partial properties.

Hess, Boehman, Tijm, Waller, Experimental Studies of the Impact of CETANER on Diesel Combustion and Emissions, SAE Technical Paper 2000-01-2886 - Diesel partial properties.

Hess, Howard, "Effect of Oxygenated Cetane Improver on Diesel Engine Combustion and Emissions," http://www.ems.psu.edu/ boehman/altfuels.html - Glyme partial properties.

Honeywell Burdick and Jackson, "Material Safety Data Sheet,"

http://www51.honeywell.com/sm/rlss/bandj/common/documents/2.4.67_msds.pdf - Glyme partial properties.

Hubbard, C. R., Peascoe, R. A., Keiser, J. R., "Pulp and Paper Plant Materials Issues Addressed by X-Ray and Neutron Diffraction Methods," International Center for Diffraction Data, Advances in X-Ray Analysis 46 (2003) - Syngas compatibility. 
Institute for the Analysis of Global Security, "Sources of Methanol," www.iags.org, 2004 - Methanol production capacity.

Intelligent Energy Europe, "Fischer-Tropsch Diesel," www.refuel.eu, 2010 - FT diesel compatibility.

International Program on Chemical Samety, "INCHEM, 1-Propanol," http://www.inchem.org/documents/ehc/ehc/ehc102.htm\#SectionNumber:1.3 - Propanol partial properties.

iSOC Technology, "MSDS: Methane," www.isocinfo.com, December 2009 - Methane compatibility.

Jaaskelainen, Hannu, “Biodiesel Fuel Standards," http://www.dieselnet.com/tech/fuel_biodiesel_std.html - FAME partial properties.

JT Baker, "MSDS, 1-Propanol," http://www.jtbaker.com/msds/englishhtml/P6390.htm - Propanol partial properties.

JT Baker, “MSDS, Gasoline,” Oct. 14, 2008, http:/www.docs.citgo.com/msds_pi/UNLEAD.pdf Gasoline and MTBE partial properties.

Kalnes, Marker, Shonnard, Koers, "Green Diesel and Biodiesel a Technoeconomic and Life Cycle Comparison," 1st Alternative Fuels Technology Conference, February 2008, Prague, Czechoslovakia - Green diesel information.

Kamara, Coetzee, "Overview of High-Temperature Fischer-Tropsch Gasoline and Diesel Quality," Energy \& Fuels 23, 2242-2247 (2009) - FT gasoline partial properties and compatibility and FT diesel compatibility.

Katikaneni, Sai P. R., Bakhshi, Narendra N., and Huffman, Don, "The New Bio-Crude: A Renewable Substitute for Petroleum?" Energy Conversion and Engineering Conference, August 1996 - Pyrolysis oil production facility costs.

Kinder Morgan, www.kne.com, February 2010 - Pipeline map/shipping information.

Kourtchev et al., Atmospheric Environment 43, 3182 (2009) - Sesquiterpene (farnasene) partial properties.

Kreame, N., Gross, C., "University of Minnesota Biofuels Database, Branched Chain Alcohol Pathway," https://www.biofuelsdatabase.org/wiki/index.php5/Branched-Chain_Alcohol_Pathway - Higher C alcohols information.

Kunkes, Simonetti, West, Serrano-Ruiz, Gartner, Dumesic, "Catalytic Conversion of Biomass to Monofunctional Hydrocarbons and Targeted Liquid-Fuel Classes," Science 322, 417-421 (2008) Sugars and alcohols information.

Lantmänen Ecobränsle AB, Sweden, "MSDS," www.ecobransle.se - FAME partial properties.

LeBlanc, Richard J., "Black Liquor Gasification Can Help Sustain Forests, Generate Ultra-Clean Biofuels," Biomass Magazine (July 2009) - Syngas compatibility.

Lindhjem and Pollack, "Impact of Biodiesel Fuels on Air Quality and Human Health: Task 1 Report," National Renewable Energy Laboratory, www.nrel.gov, May 2003 - FAME partial properties.

Magellan Pipeline Company LLC, www.magellanlp.com, December 2009 - Pipeline map/shipping information.

Mariano, Tomasella, Martino, Filho, Seleghim, Contiero, deFranceschi de Angeles, "Aerobic Biodegradation of Butanol and Gasoline Blends," Biomass and Bioenergy 33, 1175-1181 (2009) Biobutanol partial properties.

McElroy, Anduin Kirkbride, "Pipeline Potential," Biodiesel Magazine (February 2007) - Petroleum fuel distribution chain information.

Merck Index, 11th Edition, 3148 - Glyme partial properties.

Methanex, "MSDS, Methanol," http://www.methanex.com/products/documents/MSDS_USenglish.pdf, Oct. 13, 2005 - Methanol partial properties. 
Methanex, “Technical Information and Safe Handling Guide for Methanol: Version 3.0," September 2006 - Methanol compatibility.

Miao, Wu, "Biodiesel Production from Heterotrophic Microalgal Oil," Bioresource Technology 97, 841846 (2006) - Algae biodiesel compatibility.

Miltner, Makaruk, Bala, Harasek, "Biogas upgrading for transportation purposes - Operational Experiences with Austria's first Bio-CNG fuelling station," Chem. Eng. Trans. (2009), http://www.aidic.it/pres09/webpapers/134Miltner.pdf - Methane information.

Mueller, Stefan, "Assessing the Climate Change Impact of Biofuels," BioCycle Conference on Renewable Energy from Organics Recycling, October 2007 - Federal policy drivers for increased biofuels usage.

NACS Online, http://www.nacsonline.com/NACS/News/Daily/Pages/ND0917097.aspx - Hydrogen information.

National Biodiesel Board, "Materials Compatibility," www.biodiesel.org, 2004 - FAME compatibility.

National Biodiesel Board, "NBB Member Plant Locations," www.biodiesel.org, Sept. 23, 2010.

National Biodiesel Board, "US Biodiesel Production Capacity," www.biodiesel.org, June 22, 2009 FAME production capacity.

National Institutes of Health, "Substance Profiles: Isoprene," www.ntp.niehs.nih.gov, 2000 - Isoprene compatibility.

National Renewable Energy Laboratory, Biodiesel Handling and Use Guide: 4th Edition, Revised January 2009 - FAME compatibility.

National Renewable Energy Laboratory, http://www.nrel.gov/hydrogen/proj_production_delivery.html\#water - Hydrogen information.

Netse Oil, "Press Release, June 18, 2008," www.nesteoil.com - Green diesel compatibility.

Ng, Biruduganti, Stork, Comparing the Performance of SunDiesel and Conventional Diesel in a LightDuty Vehicle and Heavy-Duty Engine, SAE Technical Paper 2005-01-3776 - FT diesel partial properties.

NIST, “Chemistry WebBook," http://webbook.nist.gov/cgi/cbook.cgi?Name=farnesene\&Units=SI Sesquiterpene (farnasene) partial properties.

NuStar Logistics LP, www.nustarenergy.com, December 2009 - Pipeline map/shipping information.

Oasmaa, Peacocke, Gust, Meier, McLellan, "Norms and Standards for Pyrolysis Liquids. End-User Requirements and Specifications," Energy and Fuels C, http://www.combioproject.com/download/PDF/COMBIO_WP2_specification.pdf - Pyrolysis oils partial properties.

Oil \& Gas Journal, "Special Report: Natural Gas Pipeline Profits Surge; Oil Flat,” Sept. 1, 2008 Pipeline map/daily production information.

Pacific Northwest National Laboratory, Hydrogen Analysis Resource Center: Lower and Higher Heating Values of Hydrogen and Fuels, http:/hydrogen.pnl.gov/filedownloads/hydrogen/datasheets/lower_and_higher_heating_values.xls Butanol partial properties.

Paisley, Farris, Black, Irving, Overend, Preliminary Operating Results from the Battelle/FERCO Gasification Demonstration Plant in Burlington, Vermont, U.S.A., http://www.silvagas.com/downloads/seville.pdf - Syngas partial properties.

PDM, Inc., "MSDS d-Limonene," http://www.pdmchemicals.com/MSDS/MSDS-d-Limonene.doc Terpene partial properties.

Pipeline Research Council International, “Stress Corrosion Cracking," July 2006 - Ethanol corrosion.

Plains All-American Pipeline LP, www.paalp.com, December 2009 - Pipeline map/shipping information. 
Praxair, "Dimethyl Ether MSDS," www.praxair.com, Oct. 15, 2007 - DME partial properties.

Problem Solving Products Inc., www.pspglobal.com, December 2009 - DME compatibility

Purushothaman, Nagarajan, "Experimental Investigation on a C.I. Engine Using Orange Oil and Orange Oil with DEE," Fuel 88, 1732-1740 (2009) - Terpene information.

Qiang, Lu, Wen-Zhi, Li, Xi-Feng, Zhu, "Overview of Fuel Properties of Biomass Fast Pyrolysis Oils," Journal of Energy Conversion and Management 50 (2009) - Pyrolysis oils partial properties and compatibility.

Rantanen, Linnaila, NExBTL_Biodiesel Fuel of the Second Generation, SAE Technical Paper 2005-013771, 2005 - Green diesel partial properties and compatibility.

Refiner, a daily newsletter from www.platts.com, providing information on news, pricing, and analysis for the refining market.

Ren, Huang, Miao, Jiang, Liu, Wang, "Effect of the Addition of Diglyme in Diesel Fuel on Combustion and Emissions in a Compression-Ignition Engine," Energy and Fuels 21, 2573-2583 (2007) Methanol partial properties and glyme compatibility.

Renewable Fuels Association, 2010 Ethanol Industry Outlook, Climate of Opportunity, February 2010. Available from www.ethanolrfa.org.

Ringer, M., Putsche, V., and Scahill, J., Large Scale Pyrolysis Oil Production: A Technology Assessment and Economic Analysis, NREL Technical Report TP-510-37779, November 2006 - Pyrolysis oil production facility costs.

Rude, Schirmer, "New Microbial Fuels: A Biotech Perspective," Current Opinion in Microbiology 12, 274-281 (2009) - Sesquiterpene (farnasene) partial properties.

Sax and Lewis, Dangerous Properties of Industrial Materials: 9th Ed., 1995 - Methanol compatibility.

Science Lab, "MSDS, 1-Butanol," http://www.sciencelab.com/xMSDS-1_Butanol-9927115, Nov. 6, 2008 - Biobutanol partial properties.

Science Lab, “MSDS, d-Limonene," Nov. 6, 2008, http://www.sciencelab.com/xMSDS-DLimonene9924496 - Terpene partial properties.

Sevon, Cooper, "Modeling Combustion Efficiency in a Circulating Fluid Bed Liquid Incinerator," Chemical Engineering Science 46, 2983-2996 (1991) - Propanol partial properties.

Sharkey, "The Future of Isoprene Research," Bulletin of the Georgian National Academy of Sciences 3(3) (2009) - Isoprene partial properties.

Sharp, Christopher A., Emissions and Lubricity Evaluation of Rapeseed Derived Biodiesel Fuels, SwRI 7507, Southwest Research Institute, November 1996 - FAME partial properties.

Shihadeh, Hochgreb, Energy and Fuels 16, 552-561 (2002) - Pyrolysis oils partial properties.

Sigma-Aldrich, "MSDS, Product Number W383902" - Sesquiterpene (farnasene) partial properties.

Snare, Maki-Arvela, Simakova, Myllyoja, Murzin, "Overview of Catalytic Methods for Production of Next Generation Biodiesel from Natural Oils and Fats," Russian Journal of Physical Chemistry B 3, 3-17 (2009) - Green diesel information.

Spectrum Chemical, "Fact Sheet," http://www.speclab.com/compound/c64175.htm - Diesel and ethanol partial properties.

Stull, D. R., "Vapor Pressure of Pure Substances Organic Compounds," Ind. Eng. Chem. 39, 517-540 (1947) - Glyme partial properties.

Sunoco Pipeline Co., www.sunocologistics.com, December 2009. Five documents were selected to be representative of typical crude oil shipping requirements: Sunoco Pipeline L.P. Rules and Regulations Governing the Transportation of Crude Petroleum, Texas R.R.C. No. 11 and F.E.R.C. No. 3, Sunoco Pipeline L.P. Local Proportional Pipeline Tarriff, Texas R.R.C. No. 11 and F.E.R.C. No. 142, and Sunoco Pipeline L.P. Viscosity Table. - Pipeline map/shipping information. 
Sunsoil Inc., "Poultry Fat, B100,” Midwest Laboratories Report Number 09-334-2203, Nov. 30, 2009 Poultry fat-derived biodiesel properties.

Swanson, Satrio, Brown, Platon, "Techno-Economic Analysis of Biomass-to-Liquids Production Based on Gasification Scenarios," accepted to Fuel in February 2010 - FT production facility costs.

T2 Laboratories Inc., "Information Bulletin: Material Compatibility with Terpene Chemicals," www.t2labs.com, 1995 - Terpene compatibility.

TEPPCO Partners LP, www.teppco.com, December 2009 - Pipeline map/shipping information.

The Good Scents Company, http://www.thegoodscentscompany.com/data/rw1044061.html Sesquiterpene (farnasene) partial properties.

Transport 4: Petroleum Logistics Solutions, www.transport4.com, December 2009 - Pipeline map information.

Union Gas Limited, "Chemical Composition of Natural Gas," http://www.uniongas.com/aboutus/aboutng/composition.asp, February 2010 - Natural gas partial properties.

University of California, Low Carbon Fuel Standard_Final Report 1, http://www.energy.ca.gov/low_carbon_fuel_standard/UC_LCFS_study_Part_1-FINAL.pdf - Butanol partial properties.

UOP, “UOP/Eni Ecofining Process for Green Diesel Fuel,” www.uop.com, 2007 - Green diesel compatibility.

U.S. Department of Energy, DOE Fuel Cell Technologies Program - Hydrogen information.

U.S. Department of Energy, "Handbook for Handling, Storing, and Dispensing E85," July 2006 - Ethanol compatibility.

U.S. Department of Energy, Office of Energy Efficiency and Renewable Energy, http://www1.eere.energy.gov/hydrogenandfuelcells/storage/hydro_storage.html - Hydrogen information.

U.S. Department of Energy and North Carolina Solar Center, "Database of State Incentives for Renewables \& Efficiency," www.dsireusa.org, 2009 - State policy drivers for increased biofuels usage.

U.S. Department of Transportation, "Title 49, Subtitle B, Chapter 1, Subchapter C-Hazardous Materials Regulations," www.goaccess.gov, Dec. 8, 2009 - DOT Hazmat Transport Regulations.

U.S. Energy Information Administration, "Biofuels in the U.S. Transportation Sector," February 2007 Federal policy drivers for increased biofuels usage.

US EPA (Environmental Protection Agency), "Chemical Fact Sheet," http://www.epa.gov/opptintr/chemfact/s_mtbe.txt - MTBE partial properties.

US EPA, "Diglyme robust summary," EPA 201-15023, http://www.epa.gov/hpv/pubs/summaries/diglyme/c15023rs.pdf - Glyme partial properties.

US EPA, "High Production Volume Information System, Butanol Detailed Chemical Results," http://iaspub.epa.gov/oppthpv/quicksearch.display?pChem=101066 - Butanol partial properties.

US EPA, "High Production Volume Information System, DME Detailed Chemical Results," http://iaspub.epa.gov/oppthpv/quicksearch.display?pChem=100157 - DME partial properties.

US EPA, "High Production Volume Information System, Ethanol Detailed Chemical Results," http://iaspub.epa.gov/oppthpv/quicksearch.display?pChem=100220 - Ethanol partial properties.

US EPA, "High Production Volume Information System, Methanol Detailed Chemical Results," http://iaspub.epa.gov/oppthpv/quicksearch.display?pChem=100296 - Methanol partial properties. 
US EPA, "Methodology for Deriving Ambient Water Quality Criteria for the Protection of Human Health," 2000, http://www.epa.gov/waterscience/criteria/humanhealth/method/tsdvol2.pdf - Glyme environmental/partial properties.

US EPA, "RFS2,” www.epa.gov, January 2009 - Federal policy drivers for increased biofuels usage.

US EPA, "Summary of Workshop on Biodegradation of MTBE," February 2001, http://www.epa.gov/nrmrl/pubs/625r01001/625r01001.pdf - MTBE partial properties.

Wackett, L. P., "Biofuels (Butanol-Ethanol Production)," p. 2805 in Handbook of Hydrocarbon and Lipid Microbiology, Editor: K. N. Timmis, Springer, 2010 - Higher C alcohols information.

Wallace, W. J.; Mathews, A. L., "Density, Refractive Indices, Molar Refractions, and Viscosities of Diethylene Glycol Dimethyl Ether-Water Solutions at 25 C," J. Chem. Eng. Data 9, 267-268 (1964) - DME partial properties.

Williams Energy Partners LP, "E Grade DN Fuel Ethanol Specifications," April 2003 - Pipeline map/shipping information.

Wright, Mark M., and Brown, Robert C., "Comparative Economics of Biorefineries Based on the Biochemical and Thermochemical Platforms," Center for Sustainable Environmental Technologies Iowa State University, Biofuels, Bioproducts, and Biorefining 1, 49-56 (2007) - Ethanol, methanol, hydrogen, and FT production facility costs.

Wright, Satrio, Brown, Daugaard, "Techno-Economic Analysis of Biomass Fast Pyrolysis to Transportation Fuels," accepted to Fuel in February 2010 - Pyrolysis oil production facility costs.

www.pipeline101, a public information website maintained by American Petroleum Institute (API) and Association of Oil Pipe Lines (AOPL).

$\mathrm{Xu}, \mathrm{Miao}, \mathrm{Wu}$, "High Quality Biodiesel Production from a Microalga Chlorella Protothecoides by Heterotrophic Growth Fermenters," J. Biotechnol. 126, 499-507 (2006) - Green diesel partial properties.

Yacobucci, Brent D., Biofuels Incentives: A Summary of Federal Programs, Congressional Research Service Report for Congress, July 29, 2008 - Federal policy drivers for increased biofuels usage. 

EXHIBITS 

Oil Pipelines

E.1. Products of the Largest U.S. Interstate Oil Pipeline Companies

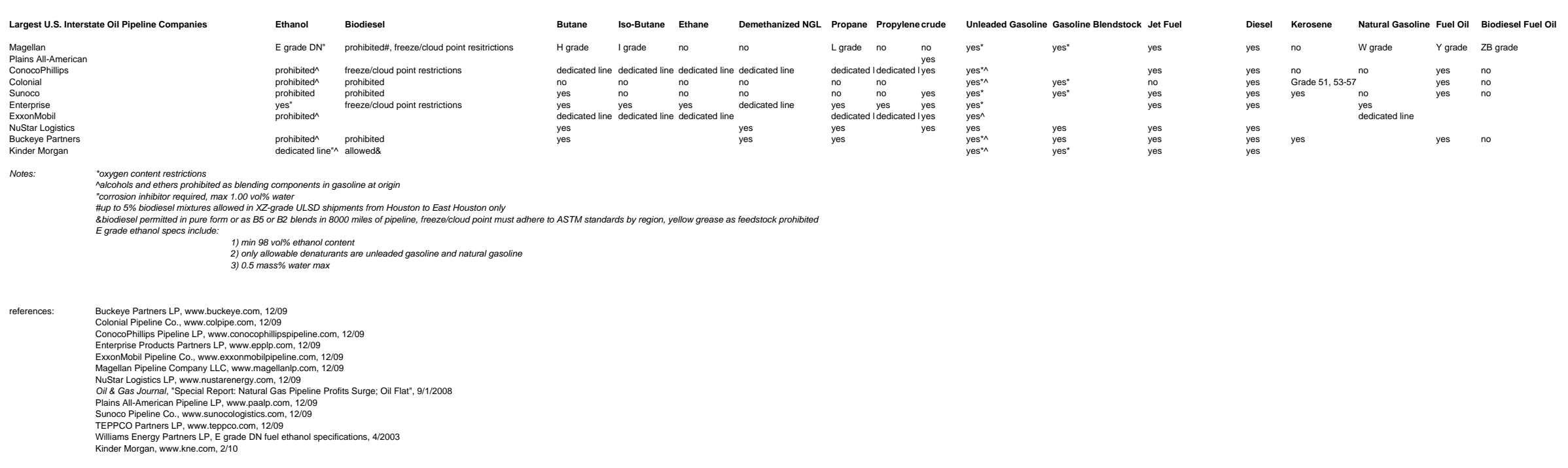




\section{Oil Piplines}

E.2. Pipeline Descriptions of the Largest U.S. Interstate Oil Pipeline Companies

\section{Largest U.S. Interstate Oil Pipeline Cos.}

Magellan

Plains All-American

ConocoPhillips

Sunoco

Enterprise

ExxonMobil

NuStar Logistics

Kinder Morgan

Notes:

*2007 mileage from "Special Report: Natural Gas Pipeline Profits Surge; Oil Flat", Oil \& Gas Journal, 9/1/2008, all other mileage and daily production data from company websites 12/4/2009

\section{Mileage}

\section{Pipelines}

9500 refined/1100 ammonia refined, ammonia

8387*, 3 mil bpd refined, crude, LPG, 3rd party
11000

refined, crude, LPG, 3rd party refined, crude, LPG

$5591^{*}, 2.3 \mathrm{mil} \mathrm{bpd}$
200 refined/3350 crude

$48000 \quad$ refined, crude, natural gas, NGL, petrochemicas 5400 efined, crude, ammon

GL, petrochemicals

Buckeye Partners, wnw.buckeye.com, $12 / 09$

ConocoPhillips Pipel, wwe LP. colpipe.com, 12/109

Enterprise Products Partners LP, www.epplp.com, 12/09

ExxonMobil Pipeline Co., www.exxonmobilipipeline.com, 12/09

Magellan Pipeline Company LLC, www.magellanlp.com, 12/0

NuStar Logistics LP, www.nustarenergy.com, 12/09

(1) Profits Surge; Oil Flat", 9/1/2008

Plains All-American Pipeline LP, www.paalp.com, $12 / 09$

TEPPCO Partners LP, www.teppco.com, 12/09

Transport 4: Petroleum Logistics Solutions, www.transport4.com, 12/09

Kinder Morgan, www.kne.com, 2/10 


\section{Oil Pipelines}

E.3. Maps of the Pipelines and Terminals of the Largest U.S. Interstate Oil Pipeline Companies

\section{ConocoPhillips}

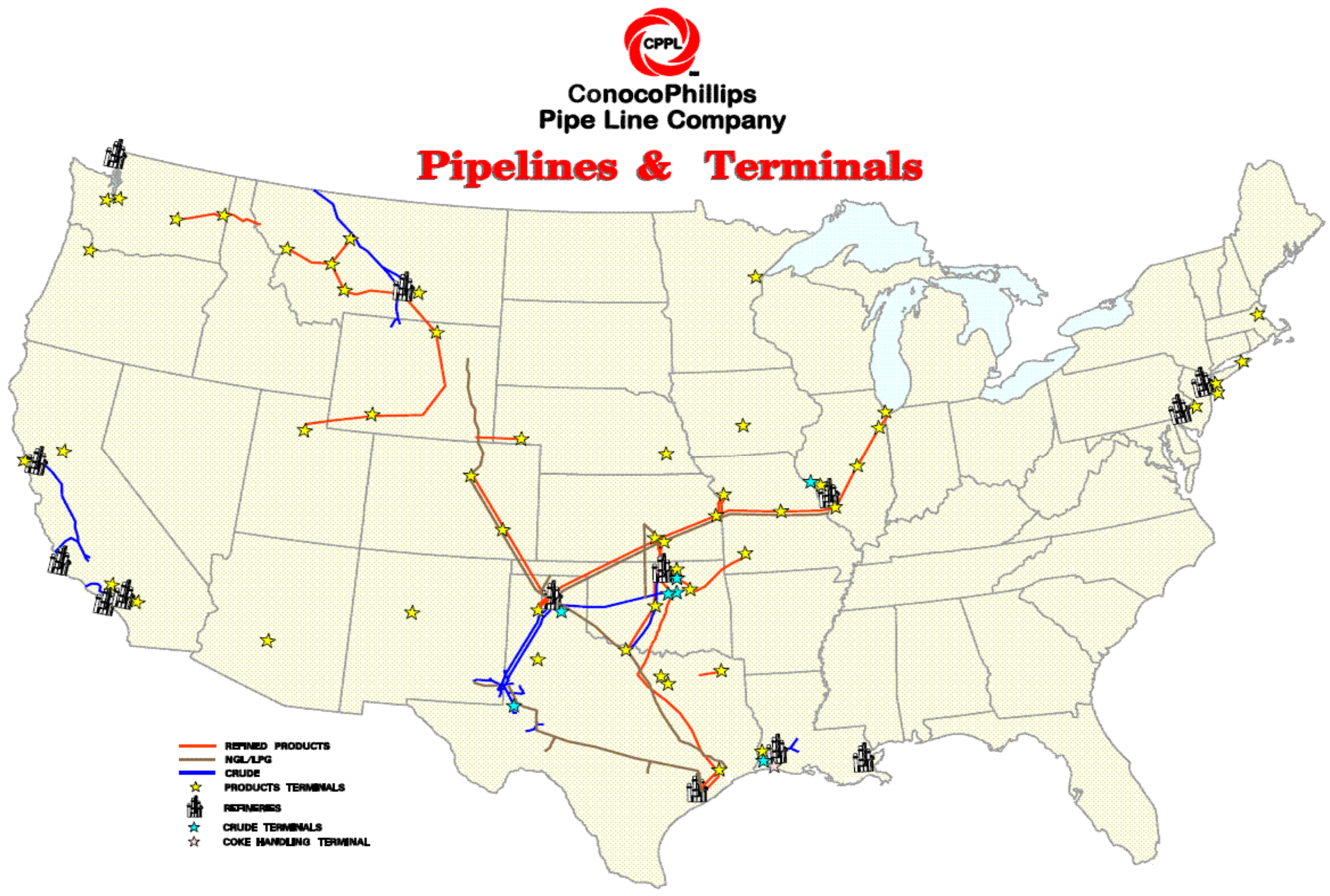




\section{Oil Pipelines}

E.3. Maps of the Pipelines and Terminals of the Largest U.S. Interstate Oil Pipeline Companies NuStar

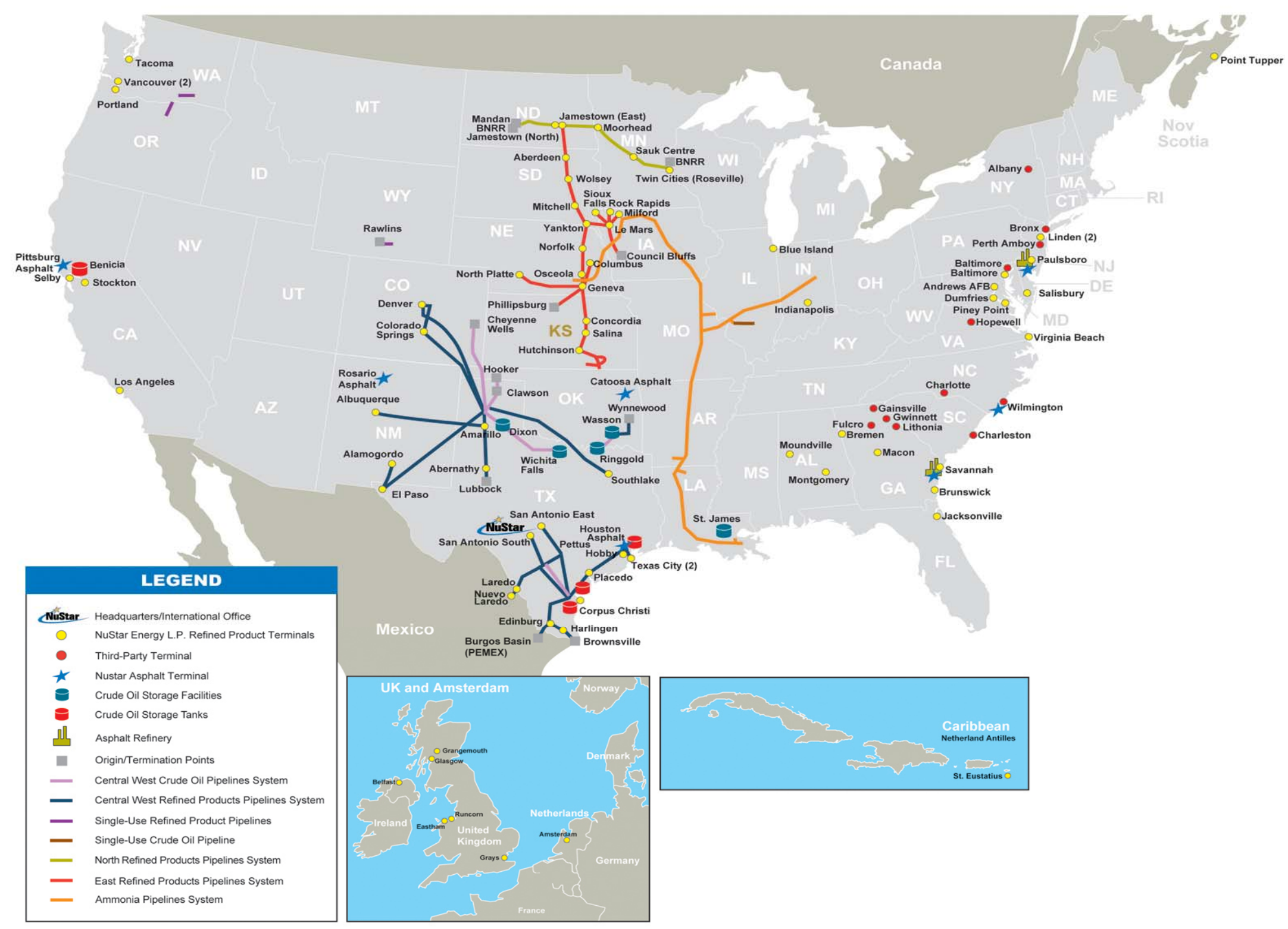




\section{Oil Pipelines}

E.3. Maps of the Pipelines and Terminals of the Largest U.S. Interstate Oil Pipeline Companies

\section{Buckeye Partners}

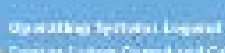

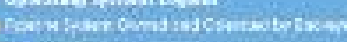
1..

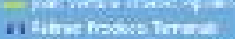

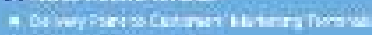

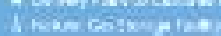

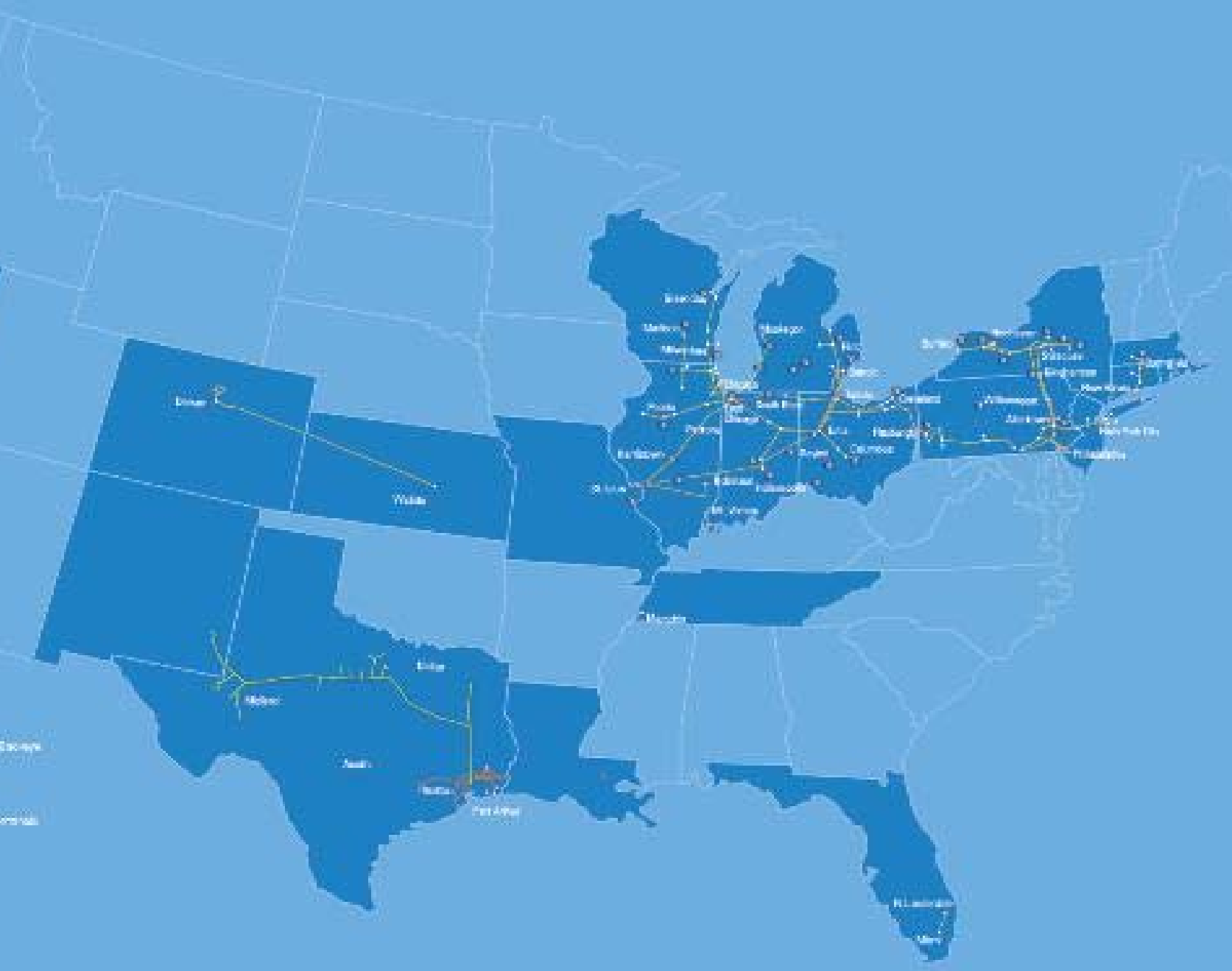




\section{Oil Pipelines}

E.3. Maps of the Pipelines and Terminals of the Largest U.S. Interstate Oil Pipeline Companies

references:

Buckeye Partners, www.buckeye.com, 12/09

ConocoPhillips Pipeline LP, www.conocophillipspipeline.com, 12/09

NuStar Logistics LP, www.nustarenergy.com, 12/09 
Hazardous Materials Transport

E.4. Transportation Options for Hazardous Fuels

\begin{tabular}{|c|c|c|c|c|c|c|}
\hline \multirow{2}{*}{$\begin{array}{c}\text { Hazardous materials } \\
\text { descriptions and } \\
\text { proper shipping } \\
\text { names }\end{array}$} & & \multicolumn{2}{|c|}{ Quantity limitations } & & & \\
\hline & Hazard Class & $\begin{array}{l}\text { Passenger } \\
\text { aircraft/rail }\end{array}$ & $\begin{array}{c}\text { Cargo } \\
\text { aircraft } \\
\text { only }\end{array}$ & Rail & Vessel & $\begin{array}{l}\text { Public } \\
\text { Highway }\end{array}$ \\
\hline Butanols & 3 & $60 \mathrm{~L}$ & $220 \mathrm{~L}$ & $\begin{array}{r}\text { private } \\
\text { track } \\
\end{array}$ & yes & yes \\
\hline Coal gas, compressed & 2.3 & Forbidden & Forbidden & yes & yes & yes \\
\hline \begin{tabular}{|l|} 
Coal tar distillates, \\
flammable
\end{tabular} & 3 & $60 \mathrm{~L}$ & $220 \mathrm{~L}$ & $\begin{array}{r}\text { private } \\
\text { track }\end{array}$ & yes & yes \\
\hline Diesel fuel & 3 & $60 \mathrm{~L}$ & $220 \mathrm{~L}$ & $\begin{array}{r}\text { private } \\
\text { track } \\
\end{array}$ & yes & yes \\
\hline Dimethyl ether & 2.1 & Forbidden & $150 \mathrm{~kg}$ & yes & $\begin{array}{r}\text { on-deck } \\
\text { only }\end{array}$ & yes \\
\hline Esters, n.o.s. & 3 & $60 \mathrm{~L}$ & $220 \mathrm{~L}$ & $\begin{array}{r}\text { private } \\
\text { track }\end{array}$ & yes & yes \\
\hline $\begin{array}{l}\text { Ethanol and gasoline } \\
\text { mixture or Ethanol } \\
\text { and motor spirit } \\
\text { mixture or Ethanol } \\
\text { and petrol mixture, } \\
\text { with more than 10\% } \\
\text { ethanol } \\
\end{array}$ & 3 & $5 \mathrm{~L}$ & $60 \mathrm{~L}$ & $\begin{array}{r}\text { private } \\
\text { track }\end{array}$ & yes & yes \\
\hline $\begin{array}{l}\text { Ethanol or Ethyl } \\
\text { alcohol or Ethanol } \\
\text { solutions or Ethyl } \\
\text { alcohol solutions } \\
\end{array}$ & 3 & $60 \mathrm{~L}$ & $220 \mathrm{~L}$ & $\begin{array}{r}\text { private } \\
\text { track } \\
\end{array}$ & yes & yes \\
\hline $\begin{array}{l}\text { Gasohol gasoline } \\
\text { mixed with ethyl } \\
\text { alcohol, with not more } \\
\text { than } 10 \% \text { alcohol }\end{array}$ & 3 & $5 \mathrm{~L}$ & $60 \mathrm{~L}$ & $\begin{array}{r}\text { private } \\
\text { track }\end{array}$ & yes & yes \\
\hline \begin{tabular}{|l|} 
Gasoline includes \\
gasoline mixed with \\
ethyl alcohol, with not \\
more than $10 \%$ \\
alcohol
\end{tabular} & 3 & $5 \mathrm{~L}$ & $60 \mathrm{~L}$ & $\begin{array}{r}\text { private } \\
\text { track }\end{array}$ & yes & yes \\
\hline $\begin{array}{l}\text { Hydrocarbons, liquid, } \\
\text { n.o.s. }\end{array}$ & 3 & $60 \mathrm{~L}$ & $220 \mathrm{~L}$ & $\begin{array}{r}\text { private } \\
\text { track } \\
\end{array}$ & yes & yes \\
\hline
\end{tabular}


Hazardous Materials Transport

E.4. Transportation Options for Hazardous Fuels

\begin{tabular}{|c|c|c|c|c|c|c|}
\hline \multirow{2}{*}{$\begin{array}{c}\text { Hazardous materials } \\
\text { descriptions and } \\
\text { proper shipping } \\
\text { names }\end{array}$} & \multicolumn{3}{|c|}{ Quantity limitations } & \multirow[b]{2}{*}{ Rail } & \multirow[b]{2}{*}{ Vessel } & \multirow[b]{2}{*}{$\begin{array}{c}\text { Public } \\
\text { Highway }\end{array}$} \\
\hline & Hazard Class & $\begin{array}{l}\text { Passenger } \\
\text { aircraft/rail }\end{array}$ & $\begin{array}{c}\text { Cargo } \\
\text { aircraft } \\
\text { only } \\
\end{array}$ & & & \\
\hline $\begin{array}{l}\text { Hydrogen, } \\
\text { compressed }\end{array}$ & 2.1 & Forbidden & $150 \mathrm{~kg}$ & yes & $\begin{array}{r}\text { on-deck } \\
\text { only }\end{array}$ & no tunnels \\
\hline $\begin{array}{l}\text { Isobutane see also } \\
\text { Petroleum gases, } \\
\text { liquefied }\end{array}$ & 2.1 & Forbidden & $150 \mathrm{~kg}$ & yes & $\begin{array}{r}\text { on-deck } \\
\text { only }\end{array}$ & yes \\
\hline $\begin{array}{l}\text { Isobutanol or Isobutyl } \\
\text { alcohol }\end{array}$ & 3 & $60 \mathrm{~L}$ & $220 \mathrm{~L}$ & $\begin{array}{r}\text { private } \\
\text { track } \\
\end{array}$ & yes & yes \\
\hline Isoprene, stabilized & 3 & $1 \mathrm{~L}$ & $30 \mathrm{~L}$ & $\begin{array}{r}\text { private } \\
\text { track }\end{array}$ & yes & yes \\
\hline Kerosene & 3 & $60 \mathrm{~L}$ & $220 \mathrm{~L}$ & $\begin{array}{r}\text { private } \\
\text { track } \\
\end{array}$ & yes & yes \\
\hline $\begin{array}{l}\text { Methane, compressed } \\
\text { or Natural gas, } \\
\text { compressed (with } \\
\text { high methane } \\
\text { content) }\end{array}$ & 2.1 & Forbidden & $150 \mathrm{~kg}$ & yes & $\begin{array}{r}\text { on-deck } \\
\text { only }\end{array}$ & yes \\
\hline \begin{tabular}{|l|} 
Methane, refrigerated \\
liquid (cryogenic \\
liquid) or Natural gas, \\
refrigerated liquid \\
(cryogenic liquid), \\
with high methane \\
content) \\
\end{tabular} & 2.1 & Forbidden & Forbidden & yes & $\begin{array}{r}\text { on-deck } \\
\text { only }\end{array}$ & no tunnels \\
\hline Methanol & 3 & $1 \mathrm{~L}$ & $60 \mathrm{~L}$ & $\begin{array}{r}\text { private } \\
\text { track }\end{array}$ & yes & yes \\
\hline Petroleum crude oil & 3 & $60 \mathrm{~L}$ & $220 \mathrm{~L}$ & $\begin{array}{r}\text { private } \\
\text { track }\end{array}$ & yes & yes \\
\hline $\begin{array}{l}\text { Petroleum distillates, } \\
\text { n.o.s. or Petroleum } \\
\text { products, n.o.s. }\end{array}$ & 3 & $60 \mathrm{~L}$ & $220 \mathrm{~L}$ & $\begin{array}{r}\text { private } \\
\text { track }\end{array}$ & yes & yes \\
\hline $\begin{array}{l}\text { Petroleum gases, } \\
\text { liquefied or Liquefied } \\
\text { petroleum gas }\end{array}$ & 2.1 & Forbidden & $150 \mathrm{~kg}$ & yes & $\begin{array}{r}\text { on-deck } \\
\text { only }\end{array}$ & yes \\
\hline
\end{tabular}




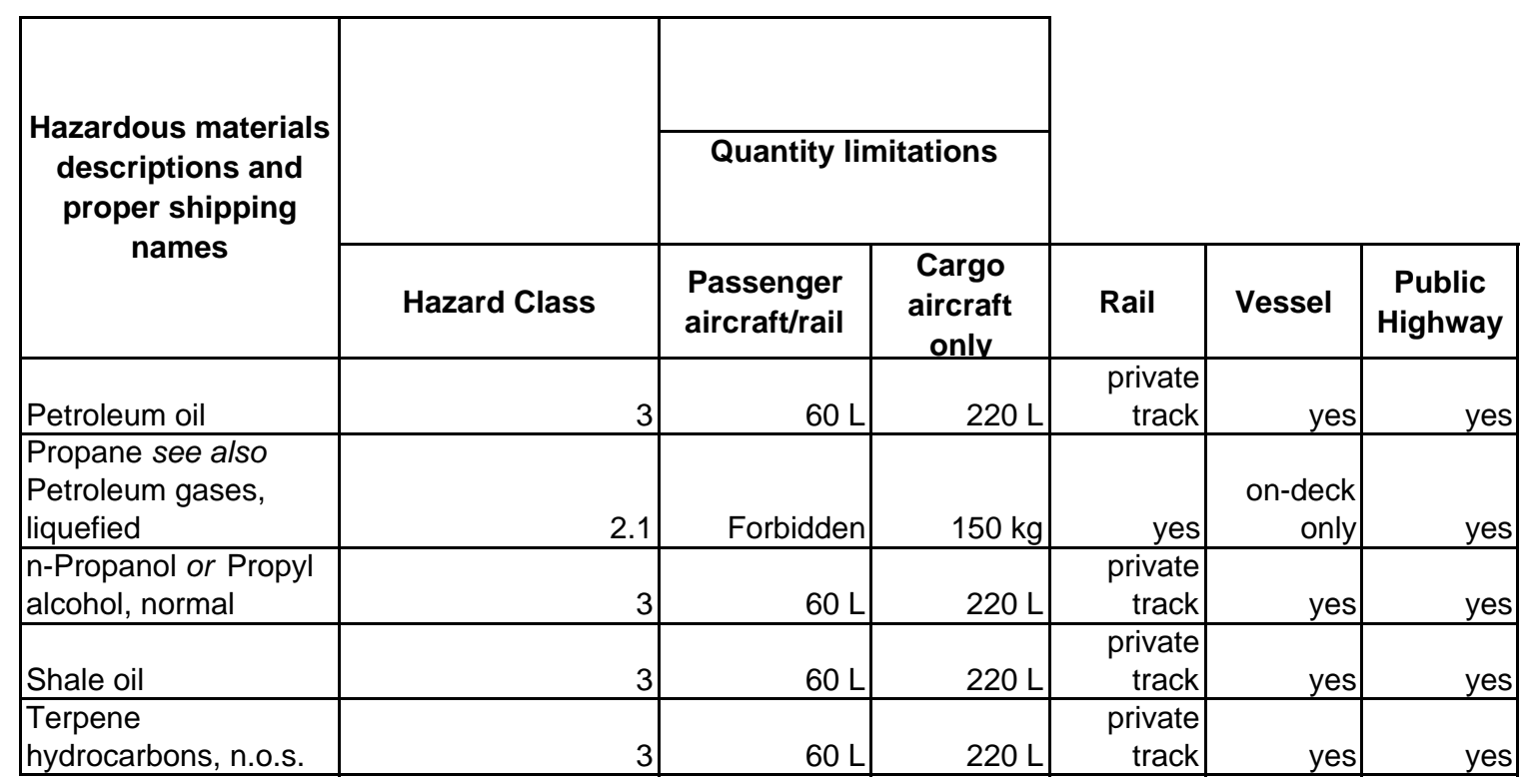

Hazard Class:

2.1 - flammable gas

2.3 - poisonous gas

3 - flammable and combustible liquid

references:

Department of Transportation, "Title 49, Subtitle B, Chapter 1,

Subchapter C - Hazardous Materials Regulations", www.goaccess.gov, 12/8/09 


\section{Distribution Chain}

E.5. Inserting Biofuels into the Current Distribution Chain

Inserting biofuels into the current distribution chain

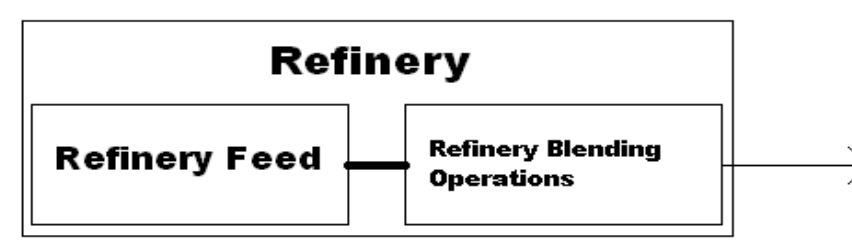

Pipeline

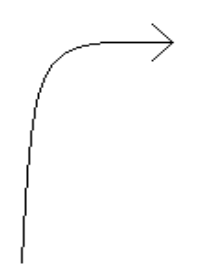

1) pyrolysis oil

potential use as refinery feed 2) algae oil

potential use as refinery feed 3) terpene

potential use as refinery feed 4) isoprene

potential use as refinery feed

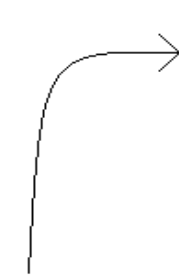

Truck

1) FAME[a]

proven successful in common carrier pipeline

not miscible in water, VP similar to diesel, low cloud

3) Fischer-Tropsch fuel

"can be directly fed into current infrastructure"

4) ethanol
some pipeline spurs allow ethanol blends

\section{Terminal}

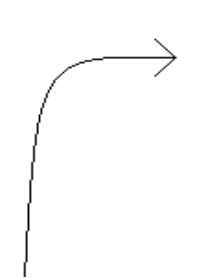

Truck

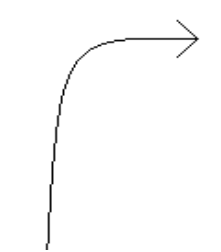

1) ethanol

miscible in water

2) diglyme

miscible in water

3) methanol

miscible in water

4) biobutanol

miscible in water

5) green diesel

high cloud point makes traditional storage difficult

6) FAME

current practice is to blend at terminals due to FAME ban in many pipelines

Notes:

High barrier for gaseous fuels due to current refinery-terminal-service station system's accommodation of liquid fuels only. Gaseous fuels necessitate separate distribution network, such as the one currently in place for propane. Limited studies concerning entering FAME and ethanol in current oil pipelines. In addition, FAME and ethanol are currently expressly banned in most pipelines.

references: please see individual fuel property and compatibility worksheets for appropriate references

[a] McElroy, Anduin Kirkbride, "Pipeline Potential", Biodiesel Magazine, 2/2007 


\section{Costs}

E.6. Projected Capital and Operating Costs for FAME, Pyrolysis Oil, Ethanol, Methanol, Hydrogen, and Fischer-Tropsch

\section{Projected Capital and Operating Costs:}

FAME

Capital costs for 4 million gal/yr (260 bpd) facility: \$6,627,540.00

Capital costs for 10 million gallyr $(650 \mathrm{bpd})$ facility: $\$ 8,820,760.00$

Operating costs for 4 million gal/yr facility using yellow grease feedstock: $\$ 8,042,396.00$
Operating costs for 4 million gal/yr facility using soybean oil feedstock: $\$ 12,502,396.00$

Operating costs for 10 million gal/yr facility using yellow grease feedstock: $\$ 18,041,034.00$

Notes:

.

Study assumes feedstock costs per Ib. are $\$ 0.17$ for yellow grease and $\$ 0.31$ for soybean oil

Feedstock is approximately $80 \%$ of total operating cost

\begin{tabular}{ccc} 
Feedstock cost $(\$ / \mathrm{b})$ & \multicolumn{2}{c}{ Biodiesel production cost $(\$ /$ gal) } \\
& $4 \mathrm{MGY}$ & $10 \mathrm{MGY}$ \\
$\$ 0.10$ & $\$ 1.19$ & $\$ 0.98$ \\
$\$ 1.15$ & $\$ 1.59$ & $\$ 1.38$ \\
$\$ 0.20$ & $\$ 1.99$ & $\$ 1.78$ \\
$\$ 0.25$ & $\$ 2.39$ & $\$ 2.18$ \\
$\$ \$ .30$ & $\$ 2.79$ & $\$ 2.58$ \\
$\$ 0.35$ & $\$ 3.19$ & $\$ 2.98$
\end{tabular}

Biodiesel Production Cost as a Function of Feedstock Cost

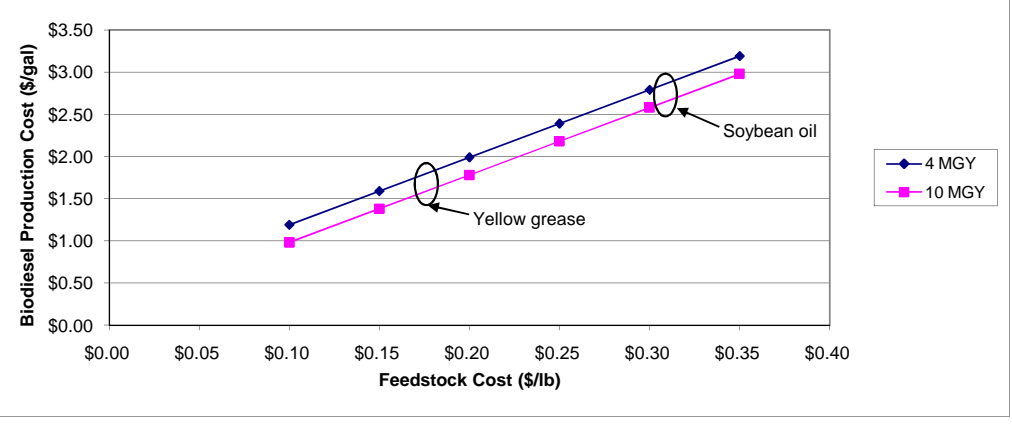

references: Fortenbery, Randall T., "Biodiesel Feasibility Study: An Evaluation of Biodiesel Feasibility in Wisconsin", University of Wisconsin Staff Paper No. 481, 3/2005 Fortenbery, Randall T., "Biodiesel reasibility Study: An Evaluation of Biodiesel Feasibility in Wisconsin", University
Coltrain, David, "Biodiesel: Is It Worth Considering?", Risk and Profit Conference, Kansas State University, 8/2002 


\title{
Costs
}

E.6. Projected Capital and Operating Costs for FAME, Pyrolysis Oil, Ethanol, Methanol, Hydrogen, and Fischer-Tropsch

\author{
Pyrolysis Oil \\ pital costs: $\$ 48,291,646.00$ \\ Operating costs: $\$ 9,600,000.00$ \\ Notes:
}

Facility uses fast pyrolysis process

Facility produces 16,091 kg/hr of bio-crude (on the order of 30 million gall/yr, $1950 \mathrm{bpd})[a]$

Assumes wood chip feedstock price of $\$ 30 / d r y$ ton

Operating costs include annual revenue of $\$ 210,000.00$ due to annual net electricity export of $4.7 \mathrm{MM} \mathrm{kWh}$

references: Ringer, M., Putsche, V., and Scahill, J., "Large Scale Pyrolysis Oil Production: A Technology Assessment and Economic Analysis", NREL Technical Report TP-510-37779, 11/2006

[a] Katikaneni, Sai P. R., Bakhshi, Narendra N., and Huffman, Don, "The New Bio-Crude: A Renewable Substitute for Petroleum?", Energy Conversion and Engineering Conference, 8/1996

Capital costs: $\$ 200-280$ million

Product Value (PV): \$2 - \$3 per gallon gasoline equivalent (GGE)

Notes:

Analysis for nth facility

PV = production cost of fuel, including 10\% return on investments

Corn stover feedstock cost $=\$ 75$ per short ton

Feedstock capacity $=2000$ dry tonne $(\mathrm{Mg})$ stover per day

Process involves production of pyrolysis oil and then hydroprocessing to diesel/gasoline-range fuel

Equipment, chemical, and labor prices in 2007 dollars

references: Anex, Aden, Kazi, Fortman, Swanson, Wright, Satrio, Brown, Daugaard, Platon, Kothandaraman, Hsu, Dutta, "Techno-Economic Comparison of Biomass-to-Transportation Fuels Via Pyrolysis, Gasification, and Biochemical Pathways", accepted to Fuel 2/10

\section{Capital costs: \$200-287 million}

Product Value (PV): \$2.11 - \$3.09 per gallon gasoline equivalent (GGE)

Notes:

Analysis for nth facility

PV = production cost of fuel, including 10\% return on investments

Corn stover feedstock cost $=\$ 75$ per short ton

Feedstock capacity $=2000$ dry tonne $(\mathrm{Mg})$ stover per day

Production $=134-220$ million Lyear

Equipment, chemical, and labor prices in 2007 dollars

references: Wright, Satrio, Brown, Daugaard, "Techno-Economic Analysis of Biomass Fast Pyrolysis to Transportation Fuels", accepted to Fuel 2/10 


\section{Costs}

E.6. Projected Capital and Operating Costs for FAME, Pyrolysis Oil, Ethanol, Methanol, Hydrogen, and Fischer-Tropsch

Ethanol
Capital costs for 25 MMGPY (1630 bpd) grain ethanol facility: $\$ 27,900,000.00$

Capital costs for 50 MMGPY (3260 bpd) cellulosic ethanol facility: $\$ 294,000,000.00$

Operating costs for 25 MMGPY grain ethanol facility: $\$ 22,000,000.00$

Operating costs for 50 MMGPY cellulosic ethanol facility: $\$ 76,000,000.00$

Notes:
25 MMGPY grain ethanol in 1999 prices, 50 MMGPY cellulosic ethanol in 2005 prices

references: Wright, Mark M. and Brown, Robert C., "Comparative Economics of Biorefineries Based on the Biochemical and Thermochemical Platforms", Center for Sustainable Environmental Technologies - lowa State University, Biofuels, Bioproducts, and Biorefining 1:49-56, 2007

\section{Capital costs: \$380-390 million}

Product Value (PV): $\$ 5$ - \$5.50 per gallon gasoline equivalent (GGE)

Notes:

Analysis for nth facility

PV = production cost of fuel, including $10 \%$ return on investments

Corn stover feedstock cost $=\$ 75$ per short ton

Feedstock capacity $=2000$ dry tonne $(\mathrm{Mg})$ stover per day

Equipment, chemical, and labor prices in 2007 dollars

references: Anex, Aden, Kazi, Fortman, Swanson, Wright, Satrio, Brown, Daugaard, Platon, Kothandaraman, Hsu, Dutta, "Techno-Economic Comparison of Biomass-to-Transportation Fuels Via Pyrolysis, Gasification, and Biochemical Pathways", accepted to Fuel 2/10

\section{Capital costs: \$327-501 million}

Product Value (PV): $\$ 5.13$ - $\$ 6.50$ per gallon gasoline equivalent (GGE)

Notes:

Analysis for nth facility

PV = production cost of fuel, including 10\% return on investments

Corn stover feedstock cost $=\$ 83$ per short ton

Feedstock capacity $=2000$ dry tonne $(\mathrm{Mg})$ stover per day

Ethanol production $=124-210$ million L/year

Equipment, chemical, and labor prices in 2007 dollars

references: Anex, Aden, Kazi, Fortman, Kothandaraman, Hsu, Dutta, "Techno-Economic Comparison of Process Technologies for Biochemical Ethanol Production from Corn Stover", Fuel 2010 


\section{Costs}

E.6. Projected Capital and Operating Costs for FAME, Pyrolysis Oil, Ethanol, Methanol, Hydrogen, and Fischer-Tropsch

\section{Methanol}

Methon facility: \$254,000,000.00

Operating costs for 87 MMGPY methanol facility: \$56,500,000.00

Notes:

87 MMGPY methanol in 2002 prices

Methanol produced from syngas from unspecified biomass feedstock

references: Wright, Mark M. and Brown, Robert C., "Comparative Economics of Biorefineries Based on the Biochemical and Thermochemical Platforms", Center for Sustainable Environmental Technologies - lowa State University, Biofuels, Bioproducts, and Biorefining 1:49-56, 2007

Hydrogen

Capital costs for 182 MMGPY (11870 bpd) hydrogen facility: $\$ 244,000,000.00$

Operating costs for 182 MMGPY hydrogen facility: $\$ 53,500,000.00$

Notes:

182 MMGPY hydrogen in 2002 prices

Hydrogen produced from syngas from unspecified biomass feedstock

references: Wright, Mark M. and Brown, Robert C., "Comparative Economics of Biorefineries Based on the Biochemical and Thermochemical Platforms", Center for Sustainable Environmental Technologies - lowa State University, Biofuels, Bioproducts, and Biorefining 1:49-56, 2007 


\section{Costs}

E.6. Projected Capital and Operating Costs for FAME, Pyrolysis Oil, Ethanol, Methanol, Hydrogen, and Fischer-Tropsch

\section{Fischer-Tropsch}

Capital costs for 35 MMGPY (2280 bpd) F-T facility: $\$ 341,000,000.00$

Operating costs for 35 MMGPY F-T facility: $\$ 87,500,000.00$

\section{Notes:
35 MMGPY F-T in 2002 prices}

F-T produced from syngas from unspecified biomass feedstock

references: Wright, Mark M. and Brown, Robert C., "Comparative Economics of Biorefineries Based on the Biochemical and Thermochemical Platforms", Center for Sustainable Environmental Technologies - lowa State University, Biofuels, Bioproducts, and Biorefining 1:49-56, 2007

Capital costs: $\$ 500-610$ million

Product Value (PV): \$4.50 - \$5 per gallon gasoline equivalent (GGE)

Notes:

Analysis for nth facility

PV = production cost of fuel, including 10\% return on investments

Corn stover feedstock cost $=\$ 75$ per short ton

Feedstock capacity $=2000 \mathrm{dry}$ tonne $(\mathrm{Mg})$ stover per day

Process involves gasification of corn stover, $\mathrm{FT}$ processing, and then hydroprocessing to diesel/gasoline-range fuel

Equipment, chemical, and labor prices in 2007 dollars

references: Anex, Aden, Kazi, Fortman, Swanson, Wright, Satrio, Brown, Daugaard, Platon, Kothandaraman, Hsu, Dutta, "Techno-Economic Comparison of Biomass-to-Transportation Fuels Via Pyrolysis, Gasification, and Biochemical Pathways", accepted to Fuel 2/10

Capital costs: $\$ 500-600$ million

Product Value (PV): $\$ 4$ - $\$ 5$ per gallon gasoline equivalent (GGE)

Notes:
Analysis for nth facility

PV = production cost of fuel, including $10 \%$ return on investments

Corn stover feedstock cost $=\$ 75$ per short ton

Feedstock capacity $=2000 \mathrm{dry}$ tonne $(\mathrm{Mg})$ stover per day

Process involves gasification of corn stover, $\mathrm{FT}$ processing, and then hydroprocessing to diesel/gasoline-range fuel

Equipment, chemical, and labor prices in 2007 dollars

references: Swanson, Satrio, Brown, Platon, "Techno-Economic Analysis of Biomass-to-Liquids Production Based on Gasification Scenarios", accepted to Fuel 2/10 


\section{Costs}

E.7. Cost Summary for Several Biofuels

\begin{tabular}{|c|c|c|c|c|c|c|c|}
\hline \multirow[t]{2}{*}{ PRODUCT } & \multicolumn{2}{|c|}{ VOLUME } & \multirow{2}{*}{$\begin{array}{c}\begin{array}{c}\text { CAPITAL } \\
\text { COSTS }\end{array} \\
\text { MM\$ }\end{array}$} & \multirow{2}{*}{$\begin{array}{c}\text { YEARLY } \\
\text { OPERATING } \\
\text { COSTS } \\
\text { MM\$ }\end{array}$} & \multirow[t]{2}{*}{ FEED } & \multirow[t]{2}{*}{ FEED COSTS } & \multirow{2}{*}{$\begin{array}{c}\text { OPERATING } \\
+ \text { FEED } \\
\text { COSTS }\end{array}$} \\
\hline & MMGPY & BPD & & & & & \\
\hline pyrolysis oil & 30 & 1950 & 48 & 9.6 & wood chips & $\$ 0.30 / d r y$ ton & $\$ 0.32$ \\
\hline ethanol & 25 & 1630 & 27.9 & 22 & grain & & $\$ 0.88$ \\
\hline ethanol & 50 & 3260 & 294 & 76 & cellulosic & & $\$ 1.52$ \\
\hline methanol & 87 & 5675 & 254 & 56.5 & biomass syngas & & $\$ 0.65$ \\
\hline FT fuel & 35 & 2283 & 341 & 87.5 & biomass syngas & & $\$ 2.50$ \\
\hline FAME & 4 & 260 & 6.6 & 8 & yellow grease & $\$ 0.17 / / b$ & $\$ 2.00$ \\
\hline FAME & 4 & 260 & 6.6 & 12.5 & soy oil & $\$ 0.31 / l b$ & $\$ 3.13$ \\
\hline FAME & 10 & 650 & 8.8 & 18 & yellow grease & $\$ 0.17 / / b$ & $\$ 1.80$ \\
\hline FAME & 10 & 650 & 8.8 & 29.2 & soy oil & $\$ 0.31 / l b$ & $\$ 2.97$ \\
\hline
\end{tabular}




\section{Policy Drivers}

E.8. Policy Drivers for Increased Biofuels Use

\section{Policy Drivers for Increased Biofuels Usage}

Omnibus Budget Reconcilliation Act of 1990 - IRS, Customs

Tax credit for small ethanol producers. Tariff on most imported ethanol.

\section{8 ammendment to 1992 Energy Policy Act - EPA, DOE}

Portion of new vehicle purchases by some fleets (including federal and many state govs) must be alternative fuel vehicles.

1998 ammendment includes biodiesel as alternative fuel.

\section{Biomass Research and Development Act of 2000 - DOE, USDA}

Provides grants for biomass research and demonstration projects.

\section{Value-Added Producer Grants Program - USDA}

Provides grants for independent producers of value-added agricultural activities, e.g. biofuel production. Scheduled to end FY2007, extended.

\section{Farm Security and Rural Investment Act of 2002 - USDA}

Provides grants and loans for renewable energy projects and energy efficiency improvements, e.g. construction of biofuel plants.

\section{Commodity Credit Corporation's Bioenergy Program - USDA}

Payments for alternative fuel producers, feedstocks included animal fats and recycled oils. Ended June 2006.

\section{American Jobs Creation Act - IRS}

Incentives to biofuel producers (feedstocks include animal fats, vegetable oils, recycled oils). Biodiesel must meet ASTM D6751 standard.

\section{Energy Policy Act - IRS, DOE}

Provides tax incentives for small biodiesel producers, expired in 2008. Establishes Renewable Fuels Standard.

Also provides loan guarantees for construction of facilities that produce ethanol from cellulose, MSW, or sugar cane.

\section{Renewable Fuels Standard - EPA}

Mandates 7.5 billion gallons of biofuels used by 2012. Mandates widespread blending of biofuels into petroleum fuels.

Provides additional incentives for cellulosic ethanol producers.

\section{Tax Relief and Healthcare Act of 2006 - IRS}

Depreciation allowance for cellulosic ethanol plant property owners.

2007 Energy Independence and Security Act (proposed expansion of Renewable Fuels Standard [RFS2]) - EPA

Mandates increased biofuels production from 9 billion gal/yr in 2008 to 36 billion gal/yr in 2022 .

Includes cellulosic (advanced, i.e. non-corn feedstock) biofuel, biodiesel, and non-road biofuel requirements. 


\section{Policy Drivers}

E.8. Policy Drivers for Increased Biofuels Use

\begin{tabular}{|c|c|}
\hline Year & Mandated Biofuels Usage (billion gallons \\
\hline 2008 & 9 \\
\hline 2009 & 11.1 \\
\hline 2010 & 12.95 \\
\hline 2011 & 13.95 \\
\hline 2012 & 15.2 \\
\hline 2013 & 16.55 \\
\hline 2014 & 18.15 \\
\hline 2015 & 20.5 \\
\hline 2016 & 22.25 \\
\hline 2017 & 24 \\
\hline 2018 & 26 \\
\hline 2019 & 28 \\
\hline 2020 & 30 \\
\hline 2021 & 33 \\
\hline 2022 & the \\
\hline
\end{tabular}

\section{Farm Bill - USDA}

Establishes tax credits for cellulosic ethanol use, among other biofuels incentives that are yet to be funded.

\section{Food, Conservation, and Energy Act of 2008 - IRS, USDA}

Tax credits for cellulosic ethanol producers and incentives for biorefineries.

\section{State Initiatives}

Low Carbon Fuel Standard - mandates at least 10\% reduction in 2007 carbon intensity in transportation fuels by 2020

carbon intensity based on life-cycle global warming intensity.

Fuel providers must track and reduce the life-cycle global warming intensity of their products.

Mandated by the state of California, 11 other states considering adopting similar proposals.

Every state and the District of Columbia have incentives and/or mandates designed to encourage the production and use of renewable energy sources, including biofuels.

These measures include, but are not limited to, the following:

$$
\begin{aligned}
& \sim \text { tax exemptions } \\
& \sim \text { fueling infrastructure grants } \\
& \sim \text { payments for production } \\
& \sim \text { state tax credits } \\
& \sim \text { renewable fuel usage mandates } \\
& \sim \text { state fleet requirements }
\end{aligned}
$$

references: Yacobucci, Brent D., "Biofuels Incentives: A Summary of Federal Programs", Congressional Research Service Report for Congress, 7/29/2008 Database of State Incentives for Renewables \& Efficiency, US Department of Energy and North Carolina Solar Center, www.dsireusa.org, 2009 U.S. Energy Information Administration, "Biofuels in the U.S. Transportation Sector", 2/2007

Georgia Forestry Commission, "Summary of State Incentives and Legislation for Renewable Energy Production", 9/2007

Farrell, Alexander E. and Sperling, Daniel, "A Low-Carbon Fuel Standard for California", 8/2007

Mueller, Stefan, "Assessing the Climate Change Impact of Biofuels", BioCycle Conference on Renewable Energy from Organics Recycling, 10/2007

Environmental Protection Agency, RFS2, www.epa.gov, 1/2009 
Diesel Fuels

E.9. FAME (Fatty Acid Methyl Esters)--Properties

\begin{tabular}{|c|c|c|c|c|c|c|c|}
\hline Properties & Soybean & Rapeseed & Poultry Fat & & US FAME Specifications & EU FAME Specifications & \\
\hline Molecular Formula & $\frac{\text { Methyl Ester }}{\text { C18 to C19 }}$ & $\frac{\text { Methyl Ester }}{\text { C18 to C19 }}$ & Methyl Ester & $\frac{\text { No. } 2}{\cos 25}$ & $\frac{\text { ASTM D6751-06a }}{\text { AST }}$ & EN 14214:2003 & $\underline{\text { Comments }}$ \\
\hline Molecular Weight (g/mol) & 300 (approx) & 300 (approx) & & $\begin{aligned} 680 \\
200(\text { approx) }\end{aligned}$ & & & \\
\hline $\begin{array}{l}\text { Elemental Composition (mass\%) } \\
\text { Carbon }\end{array}$ & 78 & 81 & & $84-87$ & & & \\
\hline Hydrogen & 11 & 12 & & $13-16$ & & & \\
\hline Oxygen & 11 & 7 & & 0 & & & \\
\hline Density $(\mathrm{g} / \mathrm{cm} 3)$ at $15 \mathrm{deg} \mathrm{C}$ & 0.87 & 0.88 & & $0.81-0.89$ & & $0.86-0.9$ & \\
\hline $\begin{array}{l}\text { Vapor Pressure kPa at } 38 \text { degC } \\
\text { Boliing Point }\end{array}$ & $<1$ & $\begin{array}{l}<1 \\
350\end{array}$ & & $\begin{array}{l}<1 \\
188-343\end{array}$ & & & \\
\hline Flash Point (degC) & & 179 & $143[\mathrm{~d}]$ & 74 & $\min 120$ & $\min 130$ & Higher flashpoint of FAME influenced by alcohol content from production process \\
\hline $\begin{array}{l}\text { Pour Point (degC) } \\
\text { Cleurd Point (deac) }\end{array}$ & -3 & -15 & & -23 & & & FAME low temperature issues \\
\hline $\begin{array}{l}\text { Cloud Point (degC) } \\
\text { High Heating Value (MJ/L) }\end{array}$ & & -6 [a] & $6.5[\mathrm{~d}]$ & -15 [a] & Report & & \\
\hline $\begin{array}{l}\text { Low Heating Value (MJ/L) } \\
\text { Water solubility in fuel (ppm) }\end{array}$ & -32 & $\begin{array}{l}-37 \\
850\end{array}$ & & 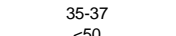 & & & SME lower energy density \\
\hline 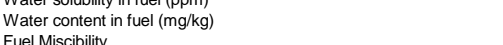 & & & & $<50$ & & $500 \max$ & \\
\hline $\begin{array}{l}\text { Fuel Miscibility } \\
\text { Solvation Potential }\end{array}$ & & High & & Low & & & \\
\hline Flammability Limits (Vol\%) & & & & & & & \\
\hline $\begin{array}{l}\text { Lower } \\
\text { Higher }\end{array}$ & & & & $\begin{array}{l}1 \\
6\end{array}$ & & & \\
\hline $\begin{array}{l}\text { Acid Number } \\
\text { Cetane Number }\end{array}$ & & & $0.39[\mathrm{~d}]$ & & & & \\
\hline $\begin{array}{l}\text { Cetane Number } \\
\text { Viscosity (mPa-s) }\end{array}$ & $3.0-6.0$ & $3.0-6.0$ & & 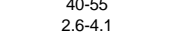 & $47 \mathrm{~min}$ & $51 \mathrm{~min}$ & FAME generally higher cetane \\
\hline $\begin{array}{l}\text { Kinematic viscosity (mm²/s) } \\
\text { Lubricity (um)** }\end{array}$ & & $140[a]$ & 4.39 [d] & 405 [a] & $1.9-6.0$ & $3.5-5.0$ & $\begin{array}{l}\text { High Frequency Reciprocating Rig Test wear scar < } 380 \text { um indicates good lubricity } \\
\text { RME better lubricity than No. } 2 \text { Diesel }\end{array}$ \\
\hline $\begin{array}{l}\text { Toxicity } \\
\text { Acute: Rodent Inhalation LC50 (g/m3) }\end{array}$ & & & & & & & \\
\hline Acute: Rat oral LD50 (mg/kg) & & $>5000[\mathrm{~b}]$ & & $12000-17500[c]$ & & & \\
\hline $\begin{array}{l}\text { AAutefisish LL50 and bacteria EC50 } \mathrm{E}(\mathrm{mg} / \mathrm{L}) \\
\text { Subchronic: Rabbit dermal } 8 \mathrm{~m} / \mathrm{kg} \text { applied for } 14 \text { days }\end{array}$ & & $>100[\mathrm{~b}]$ & & $67 \%$ mortality $[c]$ & & & \\
\hline & & & & extreme irritation $[c]$ & & & \\
\hline $\begin{array}{l}\text { Mutagenicity: Salmonella typhimurium Modified Ames Asssay } \\
\text { Partition coefficient (Kow) }\end{array}$ & & & & Negative [c] & & & \\
\hline Log Kow at 25 degc & & & & & & & \\
\hline $\begin{array}{l}\text { Bioconcentration factor }(L / k g) \\
\text { Si] }\end{array}$ & & No bioconcentration expected [b] & & & & & \\
\hline $\begin{array}{l}\text { Soli adsorrtion } \\
\text { Hall-life in water at typical env. conditions }\end{array}$ & & & & Strongly adsorb [c] & & & \\
\hline $\begin{array}{l}\text { Half-life in atmosphere } \\
\text { Biodegradation }\end{array}$ & & Readily biodegradable [b] & & & & & \\
\hline Appearance & & Yellowish liquid [b] & & clear to yellow $[c]$ & & & \\
\hline $\begin{array}{l}\text { Odor } \\
\text { Odor threshold (mg/m3) }\end{array}$ & & Mild [b] & & Mild [b] & & & \\
\hline $\begin{array}{l}\text { Odor nnestodia (mg/m3) } \\
\text { CAS Number }\end{array}$ & & & & 68334-30-5 & & & \\
\hline references (FAME and No. 2): & $\begin{array}{l}\text { Bechtold, Rich. } \\
\text { a) Sharp, Chris } \\
\text { b) Lantmänen } \\
\text { c) CITIGo No. } \\
\text { d) Sunsoil Inc., }\end{array}$ & 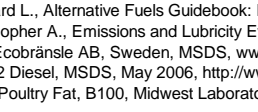 & $\begin{array}{l}\text { es, Storage, Disp } \\
\text { rof arepesed D } \\
\text { ansle.se } \\
\text { ineagle.com/MS } \\
\text { port Number 09- }\end{array}$ & $\begin{array}{l}\text { g, and Veehicle Facility M } \\
\text { 1 Biodiesel Fuels, SwRI 7 } \\
\text { tgoLowSulfurdiesel.pdf } \\
\text { 203, 11/30/09 }\end{array}$ & $\begin{array}{l}\text { lifications, SAE Order Numb } \\
07 \text {, November } 1996\end{array}$ & & \\
\hline referc & Hannu Jaask & uel Standz & t.c. & esel_std.htn & & & \\
\hline
\end{tabular}




\section{Diesel Fuels}

E.10. FAME--Compatibility and Environmental Issues

\section{Incompatible Materials}

elastomers

natural rubbers

polyurethane

lead
tin
brass
bronze
zinc
galvanized metals

\section{Compatible Materials}

elastomers

Teflon

fluorinated plastics

nylon

most fiberglass

\section{Vehicle Compatibility}

Not compatible with terne-coated steel, commonly used for fuel tanks

Nitrile and natural rubber hoses must be replaced with Viton

Compatible with Viton, typically used for most seals and gaskets

Rapeseed Methyl Ester cloud point higher than No. 2 diesel (-6 degC vs. -12 degC), leading to potential issues in cold climates

\section{Advantages}

Can be blended with diesel in any combination

Biodiesel does not separate from blends if kept above cloud point

Non-toxic

Biodegrades quicker than diesel

Requires little or no modification for use in existing engines

Disadvantages

Cleaning Effect, whereby accumulated sediments in storage tanks dissolve in FAME fuels, potentially plugging filters and causing injector deposits Stability can be an issue with certain feedstocks 


\section{Diesel Fuels}

E.10. FAME--Compatibility and Environmental Issues

\section{Transporting precautions}

Trucks/railcars must be constructed of aluminum, carbon steel, or stainless steel

Proper inspection or washout before loading

Generally only diesel or biodiesel are acceptable residuals

No residual water allowed

Hoses and seals must be made from compatible materials

Heating/insulation may be needed to keep above cloud point

\section{Environmental/Health concerns}

Non-toxic

Biodegrades quicker than diese

\section{Compatibility/Fungibility issues}

Expressly prohibited in many oil pipelines

Freeze/cloud point restrictions on diesel/blends serve as a defacto biodiesel ban in many oil pipelines

Cleaning effect leads to deposits and plugged filters both in transport and in engines

Ability to biodegrade quicker than diesel means biodiesel cannot be stored as long as diesel

Relatively high freeze and cloud points mean potential biodiesel transport may require insulation/heating

Transport by rail: requires additional private track or existing diesel transport tracks

\section{Current production}

2008 US biodiesel production: 700 million gallons

2008 US biodiesel production capacity: 2.69 billion gallons

references:

Lindhjem and Pollack, National Renewable Energy Laboratory, "Impact of Biodiesel Fuels on Air Quality and Human Health: Task 1 Report", www.nrel.gov, 5/2003 National Biodiesel Board, "US Biodiesel Production Capacity", www.biodiesel.org, 6/22/2009

National Renewable Energy Laboratory, "Biodiesel Handling and Use Guide: 4th Edition", Revised 1/2009

National Biodiesel Board, "Materials Compatibility", www.biodiesel.org, 2004

Columbia Engineered Rubber, Inc., www.columbiaerd.com, 2010

Alvarado, Peter J., "Steel vs. Plastics: The Competition for Light-Vehicle Fuel Tanks", JOM 48 (7) pp. 22-25, 1996 


\section{Diesel Fuels}

E.11. Green Diesel--Properties

"The advantages of hydrotreating [green diesel] over transesterification [biodiesel] are that the former is compatible with the current infrastructure, the process

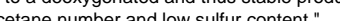

Helwani, Othman, Aziz, Fernando, Kim (2009) Technologies for Production of Biodiesel Focusing on Green Catalytic Techniques: A Review,

Fuel Processing Technology, Vol. 90, 1502 - 1514

UOP green diesel and Neste Oil NExBTL diesel are produced by hydrogen saturation and deoxygenation of vegetable oils through catalytic refining.

Wit-Avela, Simakova, Myllyoja, Murzin (2009) Overview of Catalytic Methods for Production of Next Generation Biodiesel from Natural

Oils and Fats, Russian Journal of Physical Chemistry B, Vol. 3, pp. 3-17.
Kalnes, Marker, Shonnard, Koers, Green Diesel and Biodiesel a Technoeconomic and Life Cycle Comparison, 1st Alternative Fuels Technology Conference,

Properties

Molecular Formula

Elemental Composition (mass)

Carbon

Hydrogen

Oxygen

Density (g/cm3) at $15 \mathrm{deg} \mathrm{C}$

Boiling Point

Flash Point (degC)

Pour Point (degC)

Cloud Point (degC)

Low Heating Value (MJ/L)

Water Solubility at 21 degC

Water in fuel (ppm)

Water content in fuel (mg/kg)

Fuel Miscibility
Solvation Potential

Flammability Limits (Vol\%)

Lower

Higher

Acid Number

Viscosity (mPa-s)

Kinematic viscosity $\left(\mathrm{mm}^{\wedge} 2 / \mathrm{s}\right)$

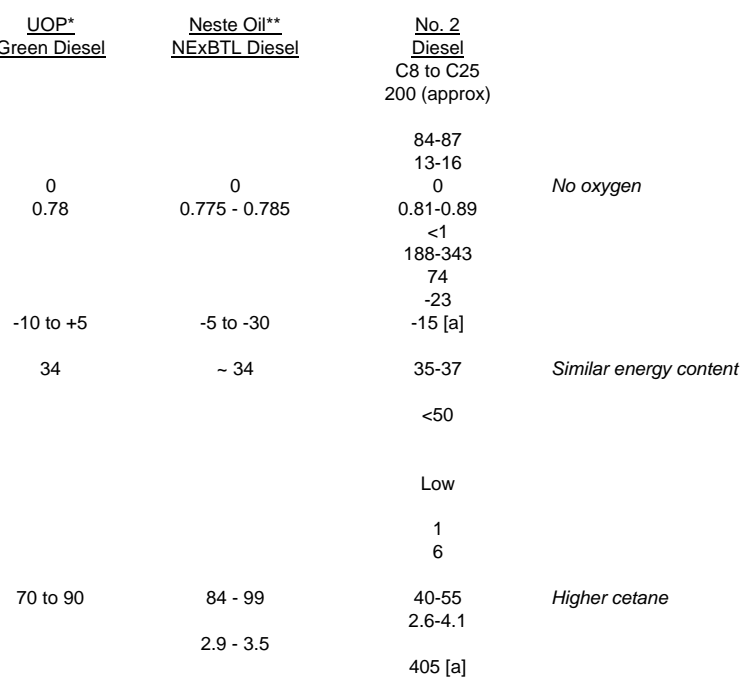




\section{Diesel Fuels}

E.11. Green Diesel--Properties

Toxicity

Acute: Rat oral LD50 (ml/kg)

Acute:LC50 for freshwater fish (Juven. Am. Shad) (ppm)

Acute:LC50 for saltwater fish (Menhaden) (ppm)

Acute:LC50 tor aquatic invertebrate (shmp) (ppm)

Acute:Aquatic plants - No observable effect concentrat
Subchronic: Rabbit dermal $8 \mathrm{~m} / \mathrm{kg}$ applied for 14 days

Chronic: Mouse dermal $0.05 \mathrm{~m} / \mathrm{kg}$ applied $3 \times$ per week for 62 wks

Mutagenicity: Salmonella typhimurium Modified Ames Asssay

Teratogenicity: Mouse oral Lowest observable effect conc. (\% calories)

Log Kow at 25 degC

Bioconcentration factor $(L / \mathrm{kg})$

Transport between Environmental Compartments

Air, water, soil, sediment (\% mass distribution)

Half-life in water at typical env. condition

Half-life in atmosphere

Biodegradation in water/sediment for 30 days

Appearance

Odor

Odor Threshold (mg/L)

* UOP LLC, a Honeywell Company
${ }^{*}$ Neste Oil Oyj, Espoo, Finland

references (UOP Green Diesel):

references (Neste NExBTL Diesel):

references (No. 2):

$$
\begin{gathered}
9[c] \\
>5[c] \\
2400[c] \\
10[c] \\
10[c] \\
67 \% \text { mortality [c] } \\
\text { extreme irritation [c] } \\
\text { Negative }[c]
\end{gathered}
$$

$$
\begin{aligned}
& \text { clear to yellow [c] } \\
& \text { Mild [b] }
\end{aligned}
$$

68334-30-5

Kalnes, Marker, Shonnard, Koers, Green Diesel and Biodiesel a Technoeconomic and Life Cycle Comparison , 1st Alternative Fuels Technology Conference, February 2008, Prague, Czechoslovakia

Rantanen, Linnaila (2005) NExBTL - Biodiesel Fuel of the Second Generation, SAE Technical Paper 2005-01-3771

Bechtold, Richard L., Alternative Fuels Guidebook: Properties, Storage, Dispensing, and Vehicle Facility Modifications, SAE Order Number R-180, 1997

a) Sharp, Christopher A., Emissions and Lubricity Evaluation of Rapeseed Derived Biodiesel Fuels, SwRI 7507, November 1996 .

c) CITIGO No. 2 Diesel, MSDS, May 2006, http://www.martineagle.com/MSDS/CitgoLowSulfurDiesel.pd/ 


\section{Diesel Fuels}

E.12. Green Diesel--Compatibility and Environmental Issues

\section{Advantages}

Higher cetane number than both petroleum diesel and FAME

Higher energy content than biodiesel

Similar properties to petroleum diesel due to lack of oxygen

Requires little or no modification to run in existing diesel engines

Low cloud point - suitable for use in cold weather

Can be blended with petroleum diesel

references:
UOP, UOP/Eni Ecofining Process for Green Diesel Fuel, www.uop.com, 2007

Netse Oil, Press Release 6/18/08, www.nesteoil.com, 2008

Rantanen, Linnaila (2005) NExBTL - Biodiesel Fuel of the Second Generation, SAE Technical Paper 2005-01-3771 


\section{Diesel Fuels}

E.13. F-T (Fischer-Tropsch Fuel)--Properties

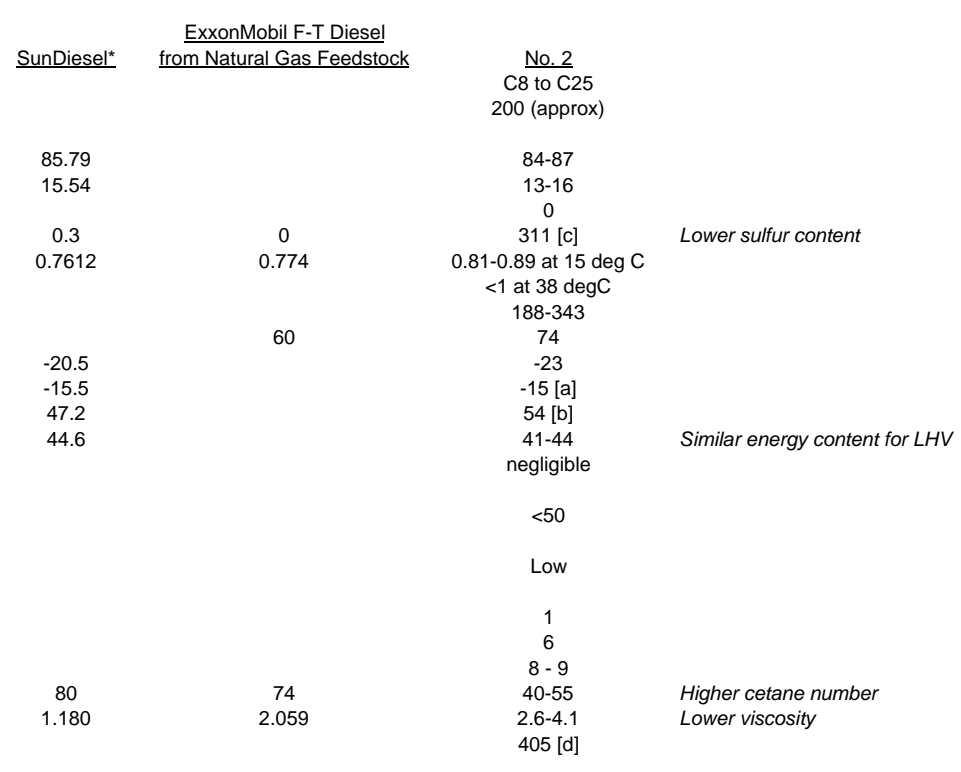




\section{Diesel Fuels}

\section{E.13. F-T (Fischer-Tropsch Fuel)--Properties}

Toxicity

Acute: Rabbit dermal $L D 50(\mathrm{~m} / \mathrm{kg})$

Acute:LC50 for freshwater fish (Juven. Am. Shad) (ppm)

Acute:LC50 for saltwater fish (Menhaden) (ppm)

Acute:LC50 for aquatic invertebrate (shrimp) (ppm)

Acute:Aquatic plants - No observable effect concentration ( $\mathrm{mg} / \mathrm{L}$ )

Subchronic: Rabbit dermal $8 \mathrm{~m} / \mathrm{kg}$ applied for 14 days

Chronic: Mouse dermal $0.05 \mathrm{ml} / \mathrm{kg}$ applied $3 \times$ per week for $62 \mathrm{wks}$

Mutagenicity: Salmonella typhimurium Modified Ames Asssay

Pog Kow at 25 degc

Bioconcentration factor $(\mathrm{L} / \mathrm{kg})$

Transport between Environmental Compartments

Air, water, soil, sediment (\% mass distribution)

Half-life in water at typical env. conditions

Half-life in atmosphere

Photodegradation half-life in air

Biodegradation in water/sediment for 30 day

Appearance

clear to yellow [e]

Odor Threshold (mg/L)

Mild [f]

CAS number

68334-30-5

* SunDiesel is a biomass to liquid fuel, which is manufactured using a Fischer-Tropsch process and produced by CHOREN Industries GmbH of Germany

references (SunDiesel):

references (ExxonMobil F-T Diesel):

references (No. 2):
$\mathrm{Ng}$, Biruduganti, Stork, Comparing the Performance of SunDiesel and Conventional Diesel in a Light-Duty Vehicle and Heavy-Duty Engine, SAE Technical Paper 2005-01-3776

Alleman, McCormick, Fischer-Tropsch Diesel Fuels - Properties and Exhaust Emissions: A Literature Review, SAE Technical Paper 2003-01-0763

Bechtold, Richard L., Alternative Fuels Guidebook: Properties, Storage, Dispensing, and Vehicle Facility Modifications, SAE Order Number R-180, 1997 a) Sharp, Christopher A., Emissions and Lubricity Evaluation of Rapeseed Derived Biodiesel Fuels, SWRI 7507, November 1996

b) Hess, Boehman, Tijm, Waller, Experimental Studies of the Impact of CETANER on Diesel Combustion and Emissions, SAE Technical Paper 2000-01-2886

c) Bertola, Boulouchos, Oxygenated Fuels for Particulate Emissions Reduction in Heavy-Duty Di-Diesel Engines with Common-Rail Fuel Injection, SAE Technical Paper 2000-01-2885

d) Sharp, Christopher A., Emissions and Lubricity Evaluation of Rapeseed Derived Biodiesel Fuels, SwRI 7507, November 1996

e) CITIGO No. 2 Diesel, MSDS, May 2006, http://www.martineagle.com/MSDS/CitgoLowSulfurDiesel.pdf

) Hess Material Data Safety Sheet No. 9909, Diesel Fuel, 10/18/2006, http://www.hess.com/ehs/msds/9909DieselFuelAllTypes.pd 


\section{Diesel Fuels}

E.14. F-T--Compatibility and Environmental Issues

\section{Vehicle Compatibility}

Cloud point comparable to No. 2 diesel, suitable for use in cold climates

"Requires little or no modification for use in current diesel engines" according to the CHOREN group

\section{Advantages}

"Requires litte or no modification for use in current diesel engines" according to the CHOREN group

produces lower NOx and PM emissions than diesel in engines due to low aromatic content

"can be directly fed into the infrastructure of existing distribution channels" according to the CHOREN group

high energy content

Higher cetane number than diesel

references:

CHOREN Industries, "Biomass-to-Liquid Fuels (BtL) - Made by CHOREN process, Environmental Impact, and Latest Developments", Automobile and Environment at Belgrade EAEC Congress, May 2005 Intelligent Energy Europe, Fischer-Tropsch Diesel, www.refuel.eu, 2010

Kamara, Coetzee, Overview of High-Temperature Fischer-Tropsch Gasline and Diesel Quality, Energy \& Fuels, 2009, 23, 2242-2247. 


\section{Diesel Fuels}

E.15. Algae Biodiesel--Properties

\section{Properties}

\section{Molecular Formula}

Molecular Weight $(\mathrm{g} / \mathrm{mol})$

Elemental Composition (mass\%)

Carbon

Hydrogen

Oxygen

Density $(\mathrm{g} / \mathrm{cm} 3)$ at $15 \mathrm{deg} C$

Vapor Pressure kPa at $38 \mathrm{degC}$

Boiling Point

Flash Point (degC)

Pour Point (degC)

Cloud Point (degC)

High Heating Value (MJ/L)

Low Heating Value $(\mathrm{MJ} / \mathrm{L})$

Water Solubility at 21 degC

Water in fuel (ppm)

Water content in fuel $(\mathrm{mg} / \mathrm{kg})$

Fuel Miscibility

Solvation Potential
Flammability Limits (Vol\%)

Lower

Higher
Acid Value (mg KOH /g)

Cetane Number

Viscosity (mPa-s)

Kinematic viscosity $\left(\mathrm{mm}^{\wedge} 2 / \mathrm{s}\right)$

Lubricity (um)
Microalg

$$
\begin{gathered}
\text { C No. } 2 \\
200 \text { to C } 25 \\
20 \text { (approx }
\end{gathered}
$$

$$
\text { 84-87 }
$$$$
\begin{gathered}
13-16 \\
0
\end{gathered}
$$

0.864

115

35 [a]$$
\begin{array}{r}
36-40[b] \\
35-37
\end{array}
$$

\begin{tabular}{|c|c|c|}
\hline$\frac{\text { US FAME Specifications }}{\text { ASTM D6751-06a }}$ & $\begin{array}{l}\text { EU FAME Specifications } \\
\text { EN 14214: } 2003\end{array}$ & \\
\hline & $0.86-0.9$ & \\
\hline $\min 120$ & $\min 130$ & Higher flash point \\
\hline Report & & Similar energy content \\
\hline & $500 \max$ & \\
\hline $\begin{array}{l}\operatorname{Max} 0.5[\mathrm{a}] \\
\quad 47 \mathrm{~min}\end{array}$ & $51 \mathrm{~min}$ & \\
\hline $1.9-6.0$ & $3.5-5.0$ & Higher kinematic viscosity \\
\hline
\end{tabular}




\section{Diesel Fuels}

E.15. Algae Biodiesel--Properties

\author{
Toxicity \\ Acute: Rat oral LD50 (ml/kg) \\ Acute: Rabbit dermal $1050(\mathrm{~m} / \mathrm{kg})$ \\ Acute:LC50 for freshwater fish (Juven. Am. Shad) (ppm) \\ Acute:LC50 for saltwater fish (Menhaden) (ppm) \\ Acute:LC50 for aquatic invertebrate (shrimp) (ppm) \\ Acute:Aquatic plants - No observable effect concentration (mg/L) \\ Chronic: Mouse derma $0.05 \mathrm{~m} / \mathrm{kg}$ applied $3 \times$ per we \\ st observable effect conc. (\% calories) \\ Partition coefficient (Kow) \\ Bioconcentration factor $(\mathrm{L} / \mathrm{kg})$ \\ Transport between Environmental Compartments \\ Air, water, soil, sediment (\% mass distribution) \\ Half-life in water at typical env. conditions \\ Half-life in atmosphere \\ Photodegradation half-life in air \\ Biodegradation in water/sediment for 30 days \\ Appearance \\ Odor Threshold (mg/L) \\ CAS number
}

references (FAME specification):

references (No. 2):

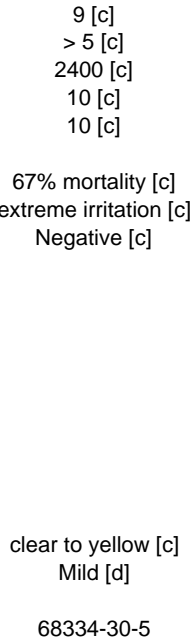

68334-30-5

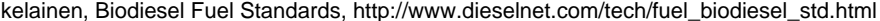

a) Xu, Miao, Wu, High Quality Biodiesel Production from a Microalga Chlorella Protothecides by Heterotrophic Growth Fermenters, 2006, 126, $499-507$.

Bechtold, Richard L., Alternative Fuels Guidebook: Properties, Storage, Dispensing, and Vehicle Facility Modifications, SAE Order Number R-180, 1997 a) Sharp, Christopher A., Emissions and Lubricity Evaluation of Rapeseed Derived Biodiesel Fuels, SwRI 7507, November 1996

bu, Miao, Wu, High Quality Biodiesel Production from a Microalga Chlorella Protothecides by Heterotrophic Growth Fermenters, 2006, 126, 499-507. c) CITIGO No. 2 Diesel, MSDS, May 2006, http://www.martineagle.com/MSDS/CitgoLowSulfurDiesel.pdf

d) Hess Material Data Safety Sheet No. 9909, Diesel Fuel, 10/18/2006, http://www.hess.com/ehs/msds/9909DieselFuelAllTypes.pd 


\section{Diesel Fuels}

E.16. Algae Biodiesel--Compatibility and Environmental Issues

\section{Advantages}

Comparable heating value to diesel, higher than FAME

Low cold filter plugging point indicates good cold weather performance

\section{Disadvantages}

High viscosity means increased pumping work required for transport

Rich in unsaturated fats, leading to oxidation susceptibility, will not comply with Euro biodiesel regulations unless further processed

references:

Miao, Wu, Biodiesel Production from Heterotrophic Microalgal Oil, Bioresource Technology , 2006, 97, 841-846 Chisti, Yusuf, Biodiesel from Microalgae , Biotechnology Advances , 2007, 25, 294-306 


\section{Diesel Fuels}

\section{E.17. DME (Dimethyl Ether)--Properties}

\section{Properties}

Molecular Formula

Molecular Weight $(\mathrm{g} / \mathrm{mol})$

Elemental Composition (mass\%)

Carbon

Hydrogen

Oxygen

Density $(\mathrm{g} / \mathrm{cm} 3)$ at $20 \mathrm{deg} \mathrm{C}$

Vapor Pressure $\mathrm{kPa}$ at $25 \mathrm{degC}$

Boiling Point (degC)

Flash Point (degC)

Pour Point (degC)

High Heating Value (MJ/L)

Low Heating Value (MJ/L)

Water Solubility at $25 \mathrm{deg} C(\mathrm{~g} / \mathrm{L})$

Fuel Miscibility

Solvation Potential

Flammability Limits (Vol\%)

Lower

Acid Number

Cetane Number

Viscosity (mPa-s)

Lubricity (um) *

Toxicity

Acute: Rat inhalation (ppm)

Acute:Freshwater Fish - No observable effect concentration (mg/L)

Acute:Daphnia - No observable effect concentration (mg/L)

Acute: Algae

Chronic: Rat - No observable effect concentration (ppm)

Genotoxicity - Bacteria, DME 0-75\%

Teratogenicity - Rat, DME 0-20,000 ppm

Partition coefficient (Kow)

Log Kow at 25 degC

Bioconcentration factor $(\mathrm{L} / \mathrm{kg})[\mathrm{j}]$

Photodegradation half-life in water

Photodegradation half-life in ar

Biodegradation $-2 \mathrm{mg} / \mathrm{L}$ in activated sludge for 28 days

Appearance

DME references:

No. 2 Diesel references:

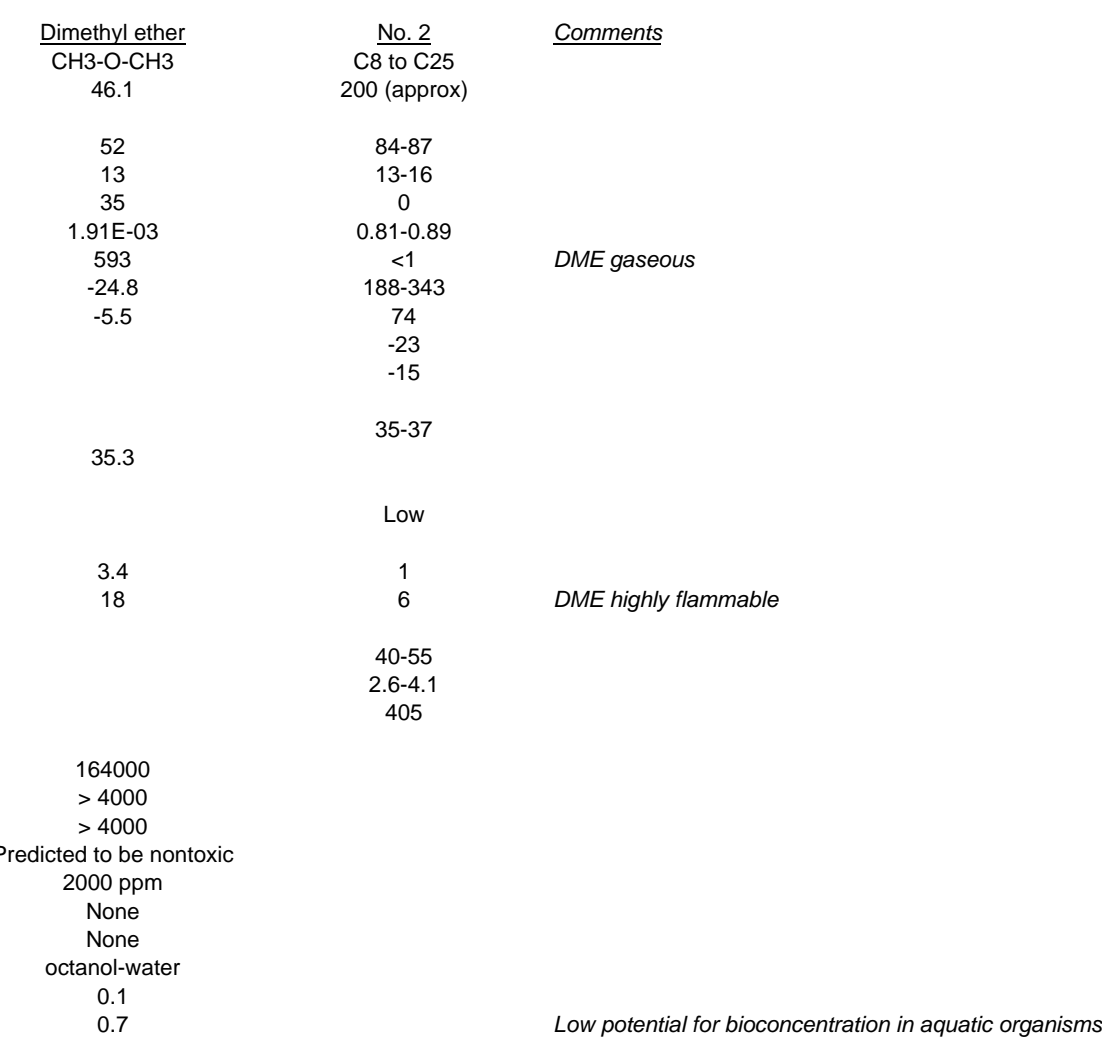

2.2 years

$5 \%$ degredation

Colorless gas [a

Slightly ethereal [a]
US EPA High Production Volume Information System, DME Detailed Chemical Results, http://iaspub.epa.gov/oppthpv/quicksearch.display?pChem=100157 a) Praxair Material Safety Data Sheet, Dimethyl Ether, P-4589-D, May 2009

Emissions and Lubricity Evaluation of Rapeseed Derived Biodiesel Fuels SwRI 7507, November 1996

Christopher A. Sharp 


\section{Diesel Fuels}

E.18. DME--Compatibility and Environmental Issues

Incompatible Materials

$\begin{array}{ll}\begin{array}{l}\text { elastomers } \\ \text { Viton }\end{array} & \frac{\text { metals }}{\text { lithium aluminum hydride }} \\ \begin{array}{l}\text { silicon rubber } \\ \text { natural rubber }\end{array} & \text { aluminum hyrdide } \\ \text { butyl rubber } & \\ \text { neoprene } & \end{array}$

\section{Compatible Materials}

elastomers metals

Teflon Carbon Steel

Buna N Stainless Steel

Aluminum

Brass

Copper

Vehicle Compatibility

Not compatible with Viton and natural rubber, commonly used materials for gaskets, seals, and hoses

Exists as a gas at STP, must be compressed for use as engine fuel

\section{Advantages}

Only minor modification needed to run in existing engines

Short carbon chain compound leads to low PM, NOx, and CO emissions

\section{Disadvantages}

Exists as gas under normal operating conditions

Highly flammable

Soluble in water

\section{Transporting Precautions}

Must be compressed to a liquid for ease of transport

\section{Environmental/Health concerns}

No known adverse ecological effects

Highly flammable

\section{Compatibility/Fungibility issues}

Only minor modification needed to run in existing engines

Must be compressed to a liquid for ease of transport

references:

Air Liquide, www.airliquide.com, 12/2009

Avantec Performance Chemicals, www.inventec.dehon.com, 12/2009

Praxair, "Dimethyl Ether MSDS", www.praxair.com, 10/15/2007

Problem Solving Products Inc., www.pspglobal.com, 12/2009

Columbia Engineered Rubber, Inc., www.columbiaerd.com, 2010

Alvarado, Peter J., "Steel vs. Plastics: The Competition for Light-Vehicle Fuel Tanks", JOM 48 (7) pp. 22-25, 1996 


\section{Diesel Fuels}

E.19. Glyme--Properties

Air Products and Chemicals, Inc. developed a process for the production of diglyme and triglyme from coal-derived synthesis gas. This could be adapted for biomass derived synthesis gas. However

issues related to the toxicity of glymes may have prevented fun her development.

sociated with 1,2

dimethoxyethane (monoglyme), diglyme, and triglyme. The literature implies that glymes are

teratogens and reproductive toxins

Air Products and Chemicals, Inc. (1998) Alternative Fuels and Chemicals from Synthesis Gas, Quarterly Report,

er DE-FC22-95PC93052.

Properties

Molecular Formula

Molecular Weight $(\mathrm{g} / \mathrm{mol})$

Elemental Composition (mass\%)

Carbon

Hydrogen

Density (g/cm3)

Vapor Pressure kPa

Boiling Point (degC)

Flash Point (degC)

Pour Point (degC)

Cloud Point (degC)

High Heating Value $(\mathrm{MJ} / \mathrm{L})$

Low Heating Value (MJ/L)

Water Solubility in fuel at 21degC (ppm)

Fuel Miscibility

Solvation Potentia

Flammability Limits (Vol\%)

Lower

Acid

Acid Number

Cetane Number

Viscosity (mPa-s)
Lubricity (um)

$\underline{\text { Diglyme }}$
C6H14O3
134.2
$53.7 \%$
$10.4 \%$
$35.8 \%$
0.938 at 25 degC
0.395 at 25 degC [i]
161.85
57 [b]
$<-17$ [f]
$26[\mathrm{~d}]$
$23[\mathrm{c}]$
Complete
at least 45 vol\% completely miscable in diesel fuel [e]
High for organics [h]
1.5
17.4
$126[\mathrm{c}]$
0.989
$783[\mathrm{~g}]$

№. 2

200 (approx)

84-87

13-1

$0.81-0.89$ at $15 \mathrm{deg} C$

$<1$ at $38 \mathrm{deg}$ Low vapor pressure for an organic solvent

88-343

$-15$

35-37

$<50$

Low

Water is soluble in diglyme

Excellent organic solvent

Wider flammability range

40-55

265 [c]

Comments
High Frequency Reciprocating Rig Test wear scar < 380 um indicates good lubricity No. 2 Diesel better lubricity than diglyme 


\section{Diesel Fuels}

\section{E.19. Glyme--Properties}

Toxicity

Acute: Rat inhalation (ppm)

Acute:LC50 for fish, daphnia and algae

Chronic: Mouse oral $(\mathrm{mg} / \mathrm{Kg})$

Partition coefficient (Kow)

Log Kow at 25 degC

Bloconcentration factor $(\mathrm{L} / \mathrm{kg})[$

Half-life in water at typical env. condition

Half-life in atmosphere

otodegradation half-life in air

Odor

references (diglyme):

references (No. 2 diesel):

\author{
$1000[\mathrm{~b}]$ \\ $>1000 \mathrm{mg} / \mathrm{L}[\mathrm{k}]$ \\ 1250 - Teratogenic; 5 - Reproductive $[\mathrm{b}]$
octanol-water \\ octanol-wate \\ $-0.36[k]$
$<100[i]$
}

When released into soil, largely evaporates,

moderately biodegrades, and can leach into groundwater [i]

$>1$ year [k]

$$
7.33 \text { hours }[\mathrm{k}]
$$

Not readily biodegradable $[\mathrm{k}]$

Clear, colorless liquid [i]
Slight aromatic odor [i]
367- Lowest reported [d]

Relativlely non-toxic for studied aquatic species

Not expected to significantly bioaccumulate

Distributes primarily to water and secondarily to soil [k]

Wallace, W.J.; Mathews, A.L., Density, Refractive Indices, Molar Refractions, and Viscosities of Diethylene Glycol Dimethyl Ether-Water Solutions at 25 C, J. Chem. Eng. Data, 1964, 9, $267-268$. a) Stull, D.R., Vapor Pressure of Pure Substances Organic Compounds, Ind. Eng. Chem., 1947, 39, 517-540

b) Honeywell, Burdick and Jackson Material Safety Data Sheet, http://www51.honeywell.com/sm/rlss/bandj/common/documents/2.4.67 msds.pdf

c) Ren, Huang, Miao, Jiang, Liu, Wang, Effect of the Addition of Diglyme in Diesel Fuel on Combustion and Emissions in a Compression-Ignition Engine, Energy and Fuels, 2007, 21, 2573-2583. d) Ferro Fine Chemicals, Product Data Sheet, diglyme, http://www.d-orland.com/pdf/Diglyme.pdf

e) Air Products and Chemicals for DOE, Alternative Fuels and Chemicals From Synthesis Gas, Quarterly Report Jan1-March 31, 1998.

http://www.osti.gov/bridge/purl.cover.jsp:jsessionid=98C35367D8BB64EC81F1D3F36F8998A0?purl=/2008-izPpak/webviewable/

f) Howard Hess, Effect of Oxygenated Cetane Improver on Diesel Engine Combusiton and Emissions

http://www.ems.psu.edu/ boehman/alffuels.html

g) Bertola, Boulouchos, Oxygenated Fuels for Particulate Emissions Reduction in Heavy-Duty Di-Diesel Engines with Common-Rail Fuel Injection, SAE Technical Paper 2000-01-2885

h) Merck Index, 11th Edition, 3148

i) J.T. Baker MSDS, http://www.jtbaker.com/msds/englishhtml/b3312.htm

k) EPA 201-15023, Diglyme robust summary, http://www.epa.gov/hpv/pubs/summaries/diglyme/c15023rs.pdf

Bechtold, Alternative Fuels Guidebook: Properties, Storage, Dispensing, and Vehicle Facility Modifications, SAE Order Number R-180, 1997

a) Sharp, Christopher A., Emissions and Lubricity Evaluation of Rapeseed Derived Biodiesel Fuels, SwRI 7507, November 1996

b) Hess, Boehman, Tijm, Waller, Experimental Studies of the Impact of CETANER on Diesel Combustion and Emissions, SAE Technical Paper 2000-01-2886

Fuel Injection, SAE Technical Paper 2000-01-2885

Chem 


\section{Diesel Fuels}

E.20. Glyme--Compatibility and Environmental Issues

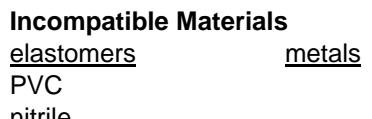

nitrile

Viton

\section{Compatible Materials}

elastomers

metals

polyethylene

all metals

Vehicle Compatibility

Compatible with fuel tank materials (polyethylene or metals)

Not compatible with typical gasket, seal, and hose materials (nitrile and Viton)

Low cloud point - suitable for use in cold climates

\section{Environmental/Health concerns}

\section{Highly toxic}

Compatibility/Fungibility issues

Necessitates o-ring and hose replacement for material compatibility

references:

Bertola, Boulouchos, Oxygenated Fuels for Particulate Emissions Reduction in Heavy-Duty Di-Diesel Engines with Common-Rail Fuel Injection, SAE Technical Paper 2000-01-2885 Columbia Engineered Rubber, Inc., www.columbiaerd.com, 2010

Alvarado, Peter J., "Steel vs. Plastics: The Competition for Light-Vehicle Fuel Tanks", JOM 48 (7) pp. 22-25, 1996 


\section{Diesel Fuels}

\section{E.21. Ethanol--Properties}

\section{Properties}

Molecular Formula

Molecular Weight $(\mathrm{g} / \mathrm{mol})$

Elemental Composition (mass\%)

Carbon

Hydrogen

Density $(\mathrm{g} / \mathrm{cm} 3)$ at $15 \mathrm{deg} C$

Vapor Pressure $\mathrm{KPa}$ at $38 \mathrm{deg} \mathrm{C}$

Boiling Point

Flash Point (degC)

Pour Point (degC)

Cloud Point (degC)

Freezing Point (degC)

High Heating Value $(\mathrm{MJ} / \mathrm{L})$

Water Solubility at 21 degC

Water in fuel (Vol\%)

Fuel Miscibility

Solvation Potentia

Flammability Limits (Vol\%)

$$
\text { Lower }
$$

Higher

Cetane Number

Viscosity (mPa-s)

Kinematic viscosity at $40 \mathrm{deg} \mathrm{C} \mathrm{m} \mathrm{m}^{\wedge} 2 / \mathrm{s}$

Lubricity (um)

Toxicity

Acute: Mouse oral LD50 (mg/kg)

Acute:LC50 for freshwater fish (trout) $(\mathrm{mg} / \mathrm{L})$

Acute:LC50 for aquatic invertebrate (daphnia) (vol\%)

Acute:Aquatic plants - No observable effect concentration (mg/L)

Chronic: Rat oral No observable effect conc. (mass\% in food)

Teratogenicity: Mouse oral Lowest observable effect conc. (\% calories)

Partition coefficient (Kow)

Log Kow at $25 \operatorname{deg} C$

Bioconcentration factor $(\mathrm{L} / \mathrm{kg})$

Transport between Environmental Compartments

Air, water, soil, sediment (\% mass distribution)

Half-life in water at typical env. conditions

Half-life in atmosphere

Photodegradation half-life in air

Biodegradation in water/sediment for 30 days

Appearance

Odor Threshold (mg/L)

CAS number

\begin{tabular}{|c|c|c|c|c|c|}
\hline $\begin{array}{c}\frac{\text { Ethanol }}{\mathrm{C} 2 \mathrm{H} 5 \mathrm{OH}} \\
46.07\end{array}$ & $\underline{E 5}$ & $\underline{E 10}$ & $\underline{E 15}$ & $\begin{array}{c}\text { No. } 2 \\
\text { C8 to C25 } \\
200 \text { (approx) }\end{array}$ & $\underline{\text { Comments }}$ \\
\hline 52.2 & & & & $84-87$ & \\
\hline 13.1 & & & & $13-16$ & \\
\hline 34.7 & & & & 0 & \\
\hline 0.79 & $0.835[\mathrm{~b}]$ & $0.833[\mathrm{~b}]$ & $0.8315[b]$ & $0.8362[\mathrm{~b}]$ & \\
\hline 15.9 & & & & $<1$ & \\
\hline 78 & & & & $188-343$ & \\
\hline 13 & $<40[b]$ & $<40[\mathrm{~b}]$ & $<40[\mathrm{~b}]$ & $\begin{array}{c}63[\mathrm{~b}] \\
-23\end{array}$ & \\
\hline & $-1.2[\mathrm{~b}]$ & $-1.2[\mathrm{~b}]$ & $-0.1[b]$ & $-3.1[b]$ & \\
\hline $\begin{array}{c}-114 \\
23\end{array}$ & & & & $\begin{array}{l}-40 \text { to }-1 \\
37-40\end{array}$ & \\
\hline 21 & $35[\mathrm{~b}]$ & 34 [b] & $33.5[\mathrm{~b}]$ & $36[\mathrm{~b}]$ & Lower energ \\
\hline
\end{tabular}

4.3
19

Low

6

$\begin{array}{lccccc}1.19 & 51.8[\mathrm{~b}] & 50[\mathrm{~b}] & 48.3[\mathrm{~b}] & 52.2[\mathrm{~b}] & \\ & & & & 2.6-4.1 & \\ & 2.88[\mathrm{~b}] & 2.45[\mathrm{~b}] & 2.47[\mathrm{~b}] & 2.88[\mathrm{~b}] & \text { Lower viscosity }\end{array}$

8300 [e]

11200 [e]

$1.5[\mathrm{e}]$
$<500[\mathrm{e}]$

$<5[\mathrm{e}]$

$25 \%[\mathrm{e}]$

octanol-water

$-0.31[\mathrm{e}]$

Low based on Kow

$13,44.8,42.1,0.039$ [e]

6 days [d]

$15.4 \mathrm{hrs}[\mathrm{e}]$

ar, water-like liquid

$0.1 \mathrm{air}, 100$ water [d]

64-17-5

Bechtold, Richard L., Alternative Fuels Guidebook: Properties, Storage, Dispensing, and Vehicle Facility Modifications, SAE Order Number R-180, 1997 NIST Chemistry WebBook

b) Dominguez, Miguel, Arjona, Millan, The Effects of Ethanol-Diesel Blended Fuels on the Performance and Emissions of Unmodified Diesel Engines, 14th European Biomass Conference and Exhibition: Biomass for Energy, Industry and Climate Protection, Paris, Oct.

c) Sharp, Christopher A., Emissions and Lubricity Evaluation of Rapeseed Derived Biodiesel Fuels, SwRI 7507, November 1996

d) Spectrum Chemical Fact Sheet, http://www.speclab.com/compound/c64175.htm

e) US EPA High Production Volume Information System, Ethanol Detailed Chemical Results, http://iaspub.epa.gov/oppthpv/quicksearch.display?pChem=100220 


\section{Diesel Fuels}

E.22. Ethanol--Compatibility and Environmental Issues

$\begin{array}{ll}\begin{array}{ll}\text { Incompatible Materials } \\ \text { elastomers }\end{array} & \text { metals } \\ \text { cork gasket material } & \text { lead } \\ \text { natural rubbers } & \text { aluminum } \\ \text { polyurethane } & \text { brass } \\ \text { PVC } & \text { terne } \\ & \text { zinc } \\ & \text { lead-based solder }\end{array}$

\section{Compatible Materials}

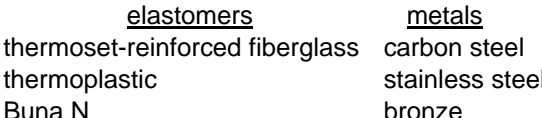
bronze

neoprene

Viton

Teflon

nitrile

polypropylene

Vehicle Compatibility

Incompatible with terne-coated steel, commonly used for fuel tanks

Incompatible with terne-coated steel, commonly used for fuel tanks
Hoses constructed from natural rubbers must be replaced with Viton, nitrile, etc.

\section{Advantages}

Requires little or no modification for use in exisitng engines

Reduces PM, CO, NOx emissions

\section{Disadvantages}

Cleaning Effect

Miscible with water

Requires co-solven 


\section{Diesel Fuels}

E.22. Ethanol--Compatibility and Environmental Issues

\section{Trasnporting Precautions}

Vessels must be cleaned out to prevent contamination due to water and cleaning effect

\section{Environmental/Health concerns \\ Toxic}

Flammable

\section{Compatibility/Fungibility issues}

Miscible with water

Cleaning effect leads to deposits and plugged filters both in transport and in engines

Transport by rail: requires additional private track or existing gasoline transport tracks

Stress corrosion cracking observed in pipelines due to ethanol

\section{Current production}

2007 US ethanol production: 6.48 billion gallons

2007 US ethanol production capacity: 7.5 billion gallons

2008 projected US ethanol production capacity: 13.3 billion gallons

references:

Biofuels Digest, "US Ethanol Production Capacity to Increase to 13.3 Billion Gallons in 2008", www.biofuelsdigest.com, 1/9/2008

Biofuels Journal, "Annual and Monthly US Ethanol Production", www.biofuelsjournal.com, 12/5/2006

Department of Energy, "Handbook for Handling, Storing, and Dispensing E85", 7/2006

Fanick, National Renewable Energy Laboratory, "Fuel and Fuel Additive Registration Testing of Ethanol-Diesel Blend for O2Diesel, Inc.", www.nrel.gov, 2/2004

Pipeline Research Council International, "Stress Corrosion Cracking", 7/2006

Columbia Engineered Rubber, Inc., www.columbiaerd.com, 2010

Alvarado, Peter J., "Steel vs. Plastics: The Competition for Light-Vehicle Fuel Tanks", JOM 48 (7) pp. 22-25, 1996 


\section{Diesel Fuels}

E.24. Sesquiterpene (Farnesene)--Complementary Information

\section{Advantages \\ Not soluble in water}

\section{Disadvantages}

Low cetane number

Poor cold flow properties

references:

Bedoukian Research Inc, MSDS P3500-90, (e)-beta-farnesene, http://www.bedoukian.com/products/displayGraphic.asp?type=m\&product=P3500-90, Aug. 3, 2007. 


\section{Gasoline Fuels}

E.25. Green Gasoline--Properties

\section{NO PUBLISHED DATA WAS FOUND FOR GREEN GASOLINE, BUT PERFORMANCE AND PROPERTIES ARE EXPECTED TO BE SIMILAR TO PETROLEUM DERIVED GASOLINE}

\section{Green Gasoline manufactured by upgrading pyrolysis oil is expected to be in production in 2014 (properties currently not published)}

An announcement on January 12, 2010 on the Green Car Congress website:

"The US Department of Energy has selected UOP, a Honeywell company, for negotiation of a $\$ 25$ million award to build a demonstration unit in Hawail

to convert cellulosic biomass into renewable hydrocarbon transportation fuels. The demonstration unit will employ the RTP rapid thermal processing technology

developed by Ensyn Corp. RTP rapidly heats biomass at ambient pressure to generate high yields of pourable, liquid pyrolysis oil. The pyrolysis oil-

essentially a bio crude oil-will then be upgraded to green transport fuels using technology developed by UOP working with DOE, the DOE's

National Renewable Energy Lab and Pacific Northwest National Laboratory (PNNL). The demonstration plant, which will be built at the Tesoro Corp. refinery

in Kapolei, Hawaii, is expected to start up in 2014. In 2009, UOP and Ensyn Corp. launched a joint venture, Envergent Technologies, LLC, to offer technology

and equipment to convert second-generation biomass into pyrolysis oil for power generation, heating fuel and for conversion into transportation fuels."

http://www.greencarcongress.com/2010/01/uop-rtp-20100112.html?utm_source=feedburner\&utm_medium=feed\&utm_campaign=Feed\%3A+greencarcongress\%2FTrBK+\%28Green+Car+Congress\%29

From website of Envergent, which is a joint company by UOP and Ensyn (green diesel manufacturers) posted on January 25, 2010:

"UOP has been selected for negotiation of a $\$ 25$ million award from the U.S. Department of Energy (DOE) to build a demonstration-scale unit that will convert

cellulosic biomass into green transportation fuels. It's a pilot test that will run as part of the DOE's effort to help reduce U.S. dependence on foreign oil,

spur the creation of the domestic bio-industry and create new jobs.

The unit will include the RTP $®$ rapid thermal processing technology to convert biomass to pyrolysis oil as well as a hydroprocessing unit to upgrade

the pyrolysis oil to green transportation fuels - primarily green gasoline."

http://blog.envergenttech.com/ 


\section{Gasoline Fuels}

E.26. Green Gasoline--Compatibility and Environmental Issues 


\section{Gaslline Fuels}

E.27. Fischer-Tropsch Fuel (FT)--Properties

From website of FT Diesel Manufacturer, CHOREN:

"Synthetic biofuel from CHOREN can at present only be used in diesel engines.

The light components generated in its production (naphtha) can be used in refineries as part of gasoline.

It is technically possible to produce pure fuel for gasoline engines, but it requires additional process stages and is not currently planned."

http://www.choren.com/en/faq/

Companies that produce FT gasoline from biomass were not found after an extensive literature search.

Information on companies which utilize the FT process in biomass to liquid production but do not produce gasoline can be found in the following references:

Hofer, R. Sustainable Solutions for Modern Economies, Royal Society of Chemistry, 2010.

See Chapter: Green Fuels - Sustainable Solutions for Transportation, pages 154-157.

Andrews, A. and Logan, J., "Fischer-Tropsch Fuels from Coal, Natural Gas, and Biomass: Background and Policy", CRS Report for Congress, 2008.

See Section: Synthetic Fuel Plants, pages 7-15.

FT Gasoline derived from coal or natural gas produced by the South African Company, Sasol

Sasol FT gasoline properties published recently in 2009 article in journal, Energy \& Fuels

Properties

density at $20 \mathrm{deg} \mathrm{C}\left(\mathrm{g} / \mathrm{cm}^{\wedge} 3\right)$

vapor pressure $(\mathrm{kPa})$

sulfur (ppm)

oxygen (mass \%)

olefins (mass \%)

aromatics (total) (vol \%)

octane

\begin{tabular}{c} 
Coal-derive \\
\hline FT Gasolin \\
\hline 0.729 \\
67 \\
$<10$ \\
0.14 \\
30 \\
29 \\
93
\end{tabular}

Natural Gas-derived Conventional So. African

$\underline{\text { FT Gasoline }} \underline{\text { Gasoline }}$

$0.748 \quad \frac{0.729}{72}$

$72 \quad 72$

$<10$

$37-27$

Reference:

Kamara, Coetzee, Overview of High-Temperature Fischer-Tropsch Gasline and Diesel Quality, Energy \& Fuels, 2009, $23,2242-2247$. 


\section{Gasoline Fuels}

E.28. Fischer-Tropsch Fuel (FT)--Compatibility and Environmental Issues

\section{Advantages}

Negligible sulfur content

Some flexibility in adjusting certain fuel properties

\section{Disadvantages}

Low octane

references: 


\section{Gasoline Fuels}

\section{E.29. Ethanol--Properties}

\section{Properties}

Molecular Formula

Molecular Weight (g/mol)

Carbon

Density (g/cm3) at 15deg C

Reid vapor pressure (psi)

Boiling Point (degC)
Flash Point (degC)

Pour Point (degC)

Cloud Point

Freezing Point (degC)

High Heating Value $(\mathrm{MJ} / \mathrm{L})$

Wow Heating Value (MJ/L)

Water in fuel (Vol\%)

Fuel Miscibility

Solvation Potential
Flammability Limits (Vol\%)

Lower
Higher

cid Number

Research Octane Number

Viscosity (mPa-s) at 20 deg

Acute. Mouse Inhalation LD50 (ppm)

Acute:LC50 for aquatc in fish (roul) (mg/L)

Acute:Aquatic plants - No observable effect concentration ( $\mathrm{mg} / \mathrm{L})$

Chronic: Rat oral No observable effect conc. (mass\% in food)

Teratogenicity: Rat inhalation
Partition coefficient (Kow)

Log Kow at 25 degC

Transport between Environmental Compartments

Air, water, soil, sediment (\% mass distribution)

Half-life in water at typical env. conditions

Half-life in atmosphere

Biodegradation in water/sediment for 30 days

Appearance

Odor Threshold (mg/L)

CAS number

references:

references (MTBE)

\begin{tabular}{|c|c|c|c|c|c|c|c|}
\hline $\begin{array}{c}\frac{\text { Ethanol }}{\mathrm{C} 2 \mathrm{H} 5 \mathrm{OH}} \\
46.07\end{array}$ & $\underline{E 10}$ & $\underline{E 20}$ & $\underline{E 50}$ & $\underline{E 85}$ & $\begin{array}{c}\frac{\text { Gasoline }}{\mathrm{C4} \text { to C12 }} \\
100-105\end{array}$ & $\begin{array}{c}\frac{\text { MTBE }}{\text { C5H12O }} \\
88.15\end{array}$ & Comments \\
\hline 52.2 & & & & $56-58$ & $85-88$ & 68 & \\
\hline 13.1 & & & & $13-14$ & $12-15$ & 14 & \\
\hline 34.7 & & & & $29-30$ & $0-4$ & 18 & \\
\hline 0.794 [b] & $0.737[b]$ & $0.744[b]$ & $0.763[\mathrm{~b}]$ & $0.786[\mathrm{~b}]$ & $0.733[b]$ & 0.7404 & \\
\hline 2 & 10.5 & 10.3 & 9 & 5 & 11 & 33 & \\
\hline 78 & & & & $49-80$ & $27-225$ & 55.2 & \\
\hline 13 & & & & slightly higher than gasoline & -43 & -25 & Higher flash \\
\hline
\end{tabular}

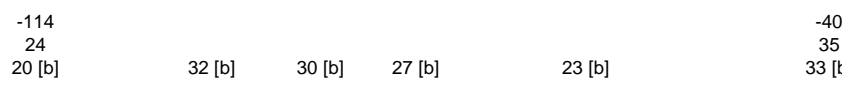

100

$35[\mathrm{~b}]$

Negligible

51260

Lower energy content

Wider than
gasoline

$95[b] \quad 98[b] \quad 102[b] \quad \begin{gathered}107[b] \\ \end{gathered} \quad \begin{array}{ll}1.07-1.08 \\ \end{array}$

1.4
7.6

$88[b]$
$0.37-0.44$

1.6
8.4

$116[\mathrm{~b}]$
1.19

Higher octane

$8300[\mathrm{e}]$

11200 [e]

$1.5[\mathrm{e}]$
$<500[\mathrm{e}]$
$<5[\mathrm{e}]$

$<5[\mathrm{e}]$
$25 \%[\mathrm{e}]$

\begin{tabular}{c} 
octanol-water \\
$-0.31[\mathrm{e}]$ \\
\hline
\end{tabular}

Low based on Kow

$13,44.8,42.1,0.039[\mathrm{e}]$

$$
\begin{gathered}
6 \text { days [d] } \\
15.4 \text { hrs [e] } \\
91 \% \text { [e] } \\
\text { clear liquid [c] } \\
0.1 \text { air, } 100 \text { water [d] } \\
64-17-5
\end{gathered}
$$

101200 [c]

1600-3900

$>100 \mathrm{mg} / \mathrm{L}$

9000 [c]

2.13 to 4.85 [c]

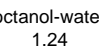

$\underset{<2}{1.24}$

streams $2.5 \mathrm{hr}$, rivers $9.5 \mathrm{hr}$, lakes 137 days$$
-6 \text { days }
$$

0.8 to 16 days [c]

Slower than aromatic hydrocarbons $[\mathrm{b}]$
clear to amber $[c]$

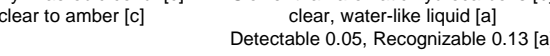

Bechtold, Richard L., Alternative Fuels Guidebook: Properties, Storage, Dispensing, and Vehicle Facility Modifications, SAE Order Number R-180, 1997 a) NIST Chemis

b) Bailey, Russel SAE Technical Paper 81044

c) Fisher Scientific MSDS, http://fscimage.fishersci.com/msds/89308.htm, March 2003

US

Cesults, http:/liaspub.epa.gov/oppthpv/quicksearch.display?pchem=100220

EPA Chemical Fact Sheet, http:///www.epa.gov/opptintr/chemfact/s m mtbe.tx

A Amerada Hess Corporation, Material Salely Dala Sheet No. 9022, Menyl ten-Butyl Eher (MTBE), April 1998

b) EPA, Summary of Workshop on Biodegradation of MTBE, February 2001, http://www.epa.gov/nrmr//pubs/625r01001/625ro1001.pd

Conversion Factors

Bailey and Russel LHV in BTU/lb

$\begin{array}{rrl}19000 & 33.0499641 \mathrm{MJ} / \mathrm{L} & \mathrm{E} \\ 18300 & 31.83233384 \mathrm{MJ} / \mathrm{L} & \mathrm{E} 10 \\ 1700 & 30.44075641 \mathrm{MJ} / \mathrm{L} & \mathrm{E} 20 \\ 15500 & 26.96181282 \mathrm{MJ} / \mathrm{L} & \mathrm{E50} \\ 13000 & 22.61313333 \mathrm{MJ} / \mathrm{L} & \mathrm{E} 85 \\ 11700 & 20.35182 \mathrm{MJ} / \mathrm{L} & \mathrm{E} 100\end{array}$




\section{Gasoline Fuels}

E.30. Ethanol--Compatibility and Environmental Issues

$\begin{array}{ll}\text { Incompatible Materials } & \\ \text { elastomers } & \text { metals } \\ \text { cork gasket material } & \text { lead } \\ \text { natural rubbers } & \text { aluminum } \\ \text { polyurethane } & \text { brass } \\ \text { PVC } & \text { terne } \\ & \text { zinc } \\ & \text { lead-based solder }\end{array}$

\section{Compatible Materials}

thermoset-reinforced fiberglass $\frac{\text { metals }}{\text { elarbon ste }}$

thermoplastic stainless steel

Buna N bronze

neoprene

Viton

Teflon

nitrile

polypropylene

\section{Vehicle Compatibility}

Incompatible with terne-coated steel, commonly used for fuel tanks, especially in older vehicles

Hoses constructed from natural rubbers must be replaced with Viton, nitrile, etc.

Low freezing point, suitable for use in cold climates

\section{Advantages}

Can be blended with gasoline in any combination

Requires little modification for use in exisitng engines

\section{Disadvantages}

Cleaning Effect

Miscible with water

Trasnporting Precautions

Vessels must be cleaned out to prevent contamination due to water and cleaning effect

\section{Environmental/Health concerns}

Toxic

Flammable

Compatibility/Fungibility issues

Miscible with water

Cleaning effect leads to deposits and plugged filters both in transport and in engines

Transport by rail: requires additional private track or existing gasoline transport tracks

Stress corrosion cracking observed in pipelines due to ethanol

\section{Current production}

2007 US ethanol production: 6.48 billion gallons

2007 US ethanol production capacity: 7.5 billion gallons

2008 projected US ethanol production capacity: 13.3 billion gallons

references:

Biofuels Digest, "US Ethanol Production Capacity to Increase to 13.3 Billion Gallons in 2008", www.biofuelsdigest.com, 1/9/2008

Biofuels Journal, "Annual and Monthly US Ethanol Production", www.biofuelsjournal.com, 12/5/2006

Department of Energy, "Handbook for Handling, Storing, and Dispensing E85", 7/2006

Pipeline Research Council International, "Stress Corrosion Cracking", 7/2006

Columbia Engineered Rubber, Inc., www.columbiaerd.com, 2010

Alvarado, Peter J., "Steel vs. Plastics: The Competition for Light-Vehicle Fuel Tanks", JOM 48 (7) pp. 22-25, 1996 


\section{Gasoline Fuels}

\section{E.31. BioButanol--Properties}

\section{Properties}

Molecular Formula

Molecular Weight $(\mathrm{g} / \mathrm{mol})$

Elemental Composition (mass\%)

Carbon

Oxygen

Density $(\mathrm{g} / \mathrm{cm} 3)$ at $15 \mathrm{deg} \mathrm{C}$

Vapor Pressure $(\mathrm{kPa})$

Boiling Point (degC)
Flash Point (degC)

Freezing Point (degC)

High Heating Value (MJ/L)

Low Heating Value (MJ/L)

Water Solubility at $21 \mathrm{deg}$ C: Water in fuel $(\mathrm{mg} / \mathrm{L})$

Fuel Miscibility

Dielectric constant ( $>15$ indicates polar solven

Flammability Limits (Vol\%)

Lower
Higher

Research Octane Number

Viscosity (mPa-s) at 20 degC

Toxicity

Acute: Rat oral LD50 (mg/kg)

Acute: Rat Inhalation LD50 (ppm)

Acute:LC50 for freshwater fish (ppm)

Acute:Aquatic plants - Half max ef

Chronic: Rat inhalation No observable effect conc. (mg/kg)

Teratogenicity: Rat inhalation No observable effect conc. (ppm)

Partition coefficient (Kow)

Log Kow at 25 degC

Bioconcentration factor $(L / \mathrm{kg})$

Transport between Environmental Compartments

Air/Soil

Photodegradation half-life in air
Biodegradation in soil in 20 days

Biodegradation in water in 24 hrs (Chemical oxygen demand method)

Appearance

Odor
Odor Threshold (ppm)

Odor Threshold (ppm)

CAS number

1-Butanol

$\mathrm{C} 4 \mathrm{H} 9 \mathrm{OH}$

Isobutanol

$\mathrm{C} 4 \mathrm{H} 9 \mathrm{OH}$

Gasoline

100-105

16.2
13.5

13.5
21.6

0.81
$18.6[j]$

$18.6[j]$
117.7
28.9

28.9
$-90[\mathrm{c}]$
$37.3[\mathrm{~h}]$

$37.3[\mathrm{~h}]$

$76700[\mathrm{~b}]$

Complete [g]

17.8 [f]

1.4
11.2
$113[\mathrm{e}]$
3

$113[\mathrm{e}]$
$3[\mathrm{~d}]$

4360 [b]

$1000[\mathrm{~b}]$

$500[\mathrm{~b}]$

$125[\mathrm{~b}$

$6000[\mathrm{~b}]$

$0.84[\mathrm{~b}]$
octanol

$<3$ (estimated) [c

Slow to moderate volatilization $[0]$

May adsorb to clay, but leaches into water $[c]$

$$
\begin{aligned}
& 2 \text { days [c] } \\
& 67 \%[c] \\
& 82 \%[c]
\end{aligned}
$$$$
\text { clear liquid }
$$

Wine-like [c]

$7.1 \mathrm{ppm}$ (in water); $0.83 \mathrm{ppm}$ (in air) [c

$$
\text { 71-36-3 }
$$

Science Lab MSDS, 1-Butanol, http://www.sciencelab.com/xMSDS-1_Butanol-9927115, Nov. 6, 2008

a) Argonne National Laboratory, Biobutanol Properties, http://www.greencarcongress.com/2008/08/argonne-investi.htm

) US EPA High Production Volume Information System, Butanol Detailed Chemical Results, http://iaspub.epa.gov/oppthpv/quicksearch.display?pChem=101066

c) EPA Chemical Fact Sheet, 1-Bulanol, hit.:Mww.epa.gov/chemfact/s_butano.tx

e) Alsfour, Butanol A Single Cylinder Engine Study: Engine Performance Internationalsolvents/solvent_pages/alcohols-htm//butanol.htm

American Chemical Society, Organic Chemistry Division, Common Organic Solvents - Table of Properties, http

h) Pacific Northwest National Laboratory, Hydrogen Analysis Resource
http://hydrogen.pnl.gov/filedownloads/hydrogen/datasheets/lower_and_higher_heating_values.xls

University of California, Low Carbon Fuel Standard-Final Report 1, http///wmw-energy_ca gov/low_carbon fuel standard/UC LCFS study Part 1-FINAL.pdf

Gautam, Martin, Combustion Characteristics of Higher Alchohol/Gasoline Blends, Proceedings of the Institution of Mechanical Engineers; Part A; Journal of Power and Energy, 2000, vol. 214, pg. 497.

references (gasoline):

Alternative Fuels Guidebook: Properties, Storage, Dispensing, and Vehicle Facility Modifications

SAE Order Number R-180, 199

Richard L. Bechtold

Tasoline, 10/14/2008, httpp://www.docs.citgo.com/msds_pi/UNLEAD.pd/ 
Gasoline Fuels

E.32. BioButanol--Compatibility and Environmental Issues

\section{Incompatible Materials \\ elastomers $\quad$ metals \\ aluminum \\ copper}

Compatible Materials

elastomers metals

steel

\section{Advantages}

Can be run in existing gasoline engines as blend or pure with little or no modification

Biodegrades easily in soil and water

Energy content closer to gasoline than ethanol

according to BP "can be transported through pipelines...can be blended at refineries"

"a commercial fuels trial confimed the compatibility of butanol with existing fuel infrastructure"

\section{Disadvantages}

Highly flammable

miscible with water

\section{Environmental/Health concerns}

Biodegrades easily in soil and water

Flammable

\section{Compatibility/Fungibility issues}

Miscible with water

Requires private track for transport by rail

Can be run in existing gasoline engines as blend or pure with little or no modification

references:

Acros Organics, "1-Butanol Material Data Safety Sheet", www.acros.com, 12/09

BP, "Biobutanol Fact Sheet", www.bp.com, 2009 


\section{Gasoline Fuels}

\section{E.33. Methanol--Properties}

\section{Properties}

Molecular Formula

(mass\%)

Hydrogen

Oxygen

Density $(\mathrm{g} / \mathrm{cm} 3)$ at $15 \mathrm{deg} \mathrm{C}$

Vapor Pressure at 38 degC $(\mathrm{kPa})$

Boiling Point (degC)

Flash Point (degC)

Pour Point (de
Cloud Point

Freezing Point (degC)

High Heating Value $(\mathrm{MJJ} / \mathrm{L})$

Water Solubility at 21 degC

Water in fuel (Vol\%)

Fuel Miscibility

Solvation Potential

Flammability Limits (Vol\%)

Lower

\section{Higher
Acid Number}

Research Octane Number

Viscosity (mPa-s) at 20 degC

Lubricity (um)

Toxicity

Acute: Mouse oral LD50 (mg/kg)

Acute: Mouse Inhalation LD50 (ppm)

Acute:Half max effective concentration for aquatic invertebrate (daphnia) $(\mathrm{mg} / \mathrm{L}$ )

Acute:Aquatic plants - Half max effective concentration (mg/L)

Teratogenicity: Rat inhalation Lowest (Gaso:No) observable effect conc. (ppm)

Partition coefficient (Kow)

Log Kow at 25 degC

Bioconcentration factor $(\mathrm{L} / \mathrm{kg})$

Transport between Environmental Compartments

Soli/Water Environment - low organic carbon in soll

Soil/Water Environment - 10\% organic carbon in soil

Half-life in water at typical env. conditions

Hall-lie in almosphere

sludge for 6 days

Appearance
Odor Threshold (ppm)
CAS number

CAS number

References:

$\begin{array}{cccc}\frac{\text { Methanol }}{\mathrm{CH} 3 \mathrm{OH}} & \underline{\text { M85 }} & \frac{\text { Gasoline }}{\mathrm{C} 4 \text { to C12 }} & \text { Comments } \\ 32.04 & & 100-105 & \\ & & & \\ 37.5 & 43-45 & 85-88 & \\ 12.6 & 40160.0 & 12-15 & \\ 49.9 & 43-44 & 0-4 & \\ 0.796 & 0.79-0.80 & 0.69-0.79 & \\ 32 & 48-103 & 48-103 & \\ 65 & 49-66 & 27-225 & \text { Higher flashpoint } \\ 11 & \text { slightly higher than gasoline } & -43 & \end{array}$

-97.5
$18[a]$

$15[\mathrm{a}]$

Iightly higher than gasoline

-40
35
$30-33$

$\begin{array}{ll}17.9-18.3 & 30-33\end{array}$

Negligible

100

100

Lower energy content
7.3
36

109
$0.57[d]$

5628 [b]

$15400[\mathrm{~b}$

$10000[\mathrm{~b}]$

$28440[\mathrm{~b}]$

2000 [joter

$-0.77[b]$

Low based on Kow

Preferentially in water $[b]$

Equal amounts in soll \& water $[b]$
2.6 days to volatilize from a pond $[b]$

17.8 days [b]

clear liquid

160 detectable, 690 recognizable $[c]$
$67-56-1$
0.8 to 16 days [a] ceadily in aerobic cond.

Alternative Fuels Guidebook: Properties, Storage, Dispensing, and Vehicle Facility Modifications

SAE Order Number R-180, 1997

Richard L. Bechtold

Tosoline, 10/14/2008, http://www.docs.citgo.com/msds pi/UNLEAD.pdf

References: a) NIST Chemistry WebBook

Methanol $\quad$ b) US EPA High Production Volume Information System, Methanol Detailed Chemical Results, http://iaspub.epa.gov/oppthpv/quicksearch.display?pChem=100296 c) Methanex MSDS, Methanol, http://www.methanex.com/products/documents/MSDS_USenglish.pdf, Oct. 13, 2005

d) Assael and Polimatidou, Measurements of the Viscosity of Alcohols in the Temperature Range 290-340 K at Pressures up to $30 \mathrm{Mpa}$, International Journal of Thermophysics, 1994, 15, 95-107.

c) Ren, Huang, Miao, Jiang, Liu, Wang, Effect of the Addition of Diglyme in Diesel Fuel on Combustion and Emissions in a Compression-Ignition Engine, Energy and Fuels, 2007, 21, 2573-2583. 


\section{Gasoline Fuels}

E.34. Methanol--Compatibility and Environmental Issues

Incompatible Materials elastomers

$$
\begin{aligned}
& \text { metals } \\
& \text { lead } \\
& \text { magnesium } \\
& \text { platinum }
\end{aligned}
$$

oxidizing materials

\section{Compatible Materials$$
\underline{\text { elastomers }} \quad \frac{\text { metals }}{\text { mild steel }}
$$ \\ nitrile}

ethylene propylene

Teflon

natural rubber

\section{Vehicle Compatibility}

Incompatible with terne-coated steel, commonly used for fuel tanks in older vehicles

Compatible with nitrile and natural rubber, commonly used for hoses

Low freezing point, suitable for use in cold climates

\section{Advantages}

Can be converted to hydrogen at relatively low temps

Widely distributed currently

Biodegrades easily in soil and water

Disadvantages

Highly flammable

Miscible in water

Existing engines would require modifcation

Environmental/Health concerns

Biodegrades easily in soil and water

Flammable

Short term harmful effects on aquatic life in spill zone

\section{Compatibility/Fungibility issues}

Miscible with water

Requires private track for transport by rail

Engine modification required for use in engines

\section{Current production}

2004 US methanol production capacity: 2.6 billion gallons

references:

Methanex, "Technical Information and Safe Handling Guide for Methanol: Version 3.0", 9/2006

Sax and Lewis, "Dangerous Properties of Industrial Materials: 9th Ed.", 1995

"Hawley's Condensed Chemical Dictionary: 11th Ed.", 1987

Institute for the Analysis of Global Security, "Sources of Methanol", www.iags.org, 2004

Columbia Engineered Rubber, Inc., www.columbiaerd.com, 2010

Alvarado, Peter J., "Steel vs. Plastics: The Competition for Light-Vehicle Fuel Tanks", JOM 48 (7) pp. 22-25, 1996 


\section{Gasoline Fuels}

\section{E.35. Propanol--Properties}

\section{Properties}

Molecular Formula

Molecular Weight $(\mathrm{g} / \mathrm{mol})$

Elemental Composition (mass\%)

Carbon

Hydrogen

Density (g/cm3)

Reid Vapor Pressure (kPa)

Boiling Point (degC)

Flash Point (degC)

Pour Point (degC)
Cloud Point

Freezing Point $(\operatorname{deg} \mathrm{C})$

High Heating Value $(\mathrm{MJ} / \mathrm{L})$

Low Heating Value (MJ/L)

Water Solubility at 21 deg

Fuel Miscibility

Solvation Potential
Flammability Limits (Voly)

Flammability Limits (Vol\%)

Lower

Acid Number

Research Octane Number

Viscosity (mPa-s) at 25 degC

Lubricity (um)

Acute: Rat oral LD50 (mg/kg)

Acute: Rat oral LD50 (mg/kg)
Acute: Mouse Inhalation LD50 (ppm)

Acute: Rabbit eye irritation (mg)

Acute: Rabbit dermal (mg)

Acute:LC50 for fish 96-hour values(ppm)

for aquatic invertebrate (daphnia) $(\mathrm{mg} / \mathrm{L})$

Chronic: Rat inhalation Lowest observable effect conc. $(\mathrm{mg} / \mathrm{L}$ )

Teratogenicity: Rat inhalation No observable effect conc. (ppm)

Partition coefficient (Kow)
Log Kow at 25 degC

Log Kow at 25 degC

Transport between Environmental Compartments

Soil/Air

Soil'Water

Air/Water

alf-life in water at typical env. conditions

Photodegradation half-life in a

Biodegradatio

Appearance

ld (ppm)

AS number

references:

refences:

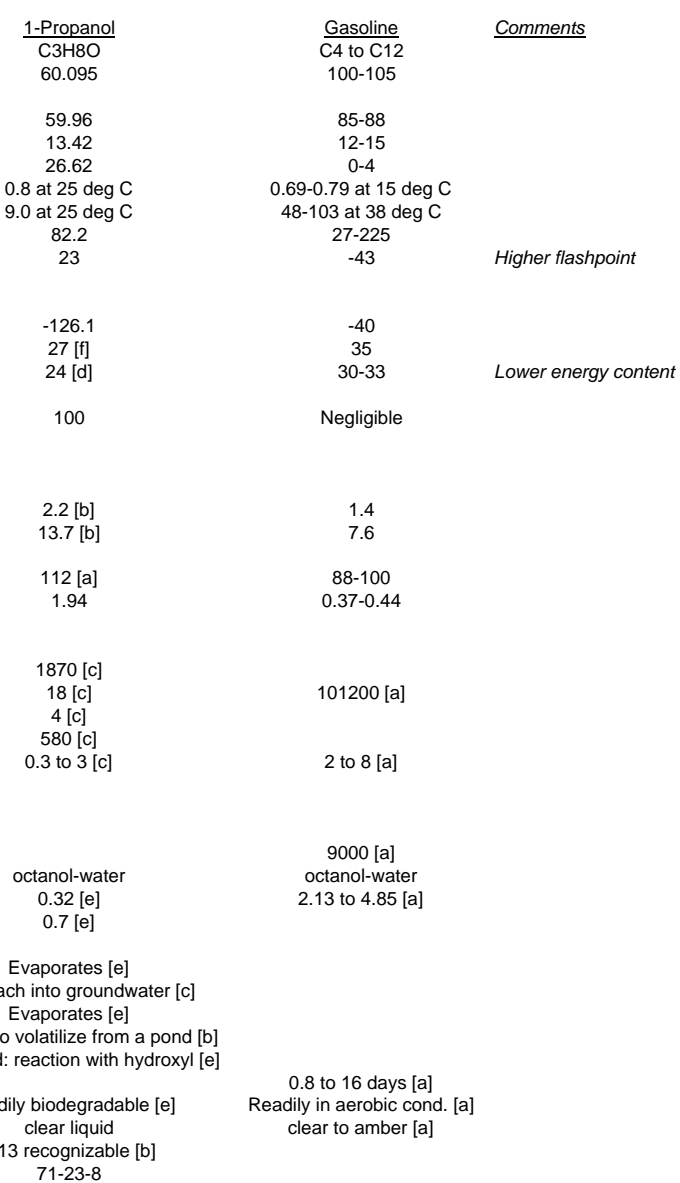

California Air Resources Board, Solvents Database, 1-propanol, http://mww.arb.ca.gov/db/solvents/solvent_pages/Alcohols-HTML/propanol.htm

a) Gautam, Martin, Combustion Characteristics of Higher Alchohol/Gasoline Blends, Proceedings of the Institution of Mechanical Engineers; Part A; Journal of Power and Energy, 2000, vol. 214, pg. 497. c) JT Baker MSDS, 1-Propanol, http://www.jtbaker.com/msds/englishtmm//P6390.htm

d) Sevon, Cooper, Modeling Combustion Efficiency in a Circulating Fluid Bed Liquid Incinerator, Chemical Engineering Science, 1991, Vol. 46, pp. 2983-2996.

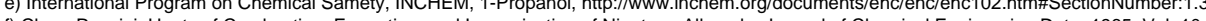

Alternative Fuels Guidebook: Properties, Storage, Dispensing, and Vehicle Facility Modifications

SAE Order Number R-180, 1997

Richard L. Bechtold Baker MSDS, Gasoline, 10/14/2008, http:///www.docs.citgo.com/msds _pi/UNLEAD.pd/ 
Gasoline Fuels

E.36. Propanol--Compatibility and Environmental Issues

Incompatible Materials

elastomers

metals

alkali metals

Compatible Materials

elastomers

$\frac{\text { metals }}{\text { steel }}$

Advantages

Biodegrades easily

Disadvantages

Highly flammable

\section{Environmental/Health concerns}

Biodegrades easily in soil and water

Flammable

\section{Compatibility/Fungibility issues}

Requires private track for transport by rail

references:

Cameo Chemicals, "n-Propanol Chemical Data Sheet", www.cameochemicals.noaa.gov, 12/09

Dow Chemicals, "Dow n-Propanol Product Safety Assessment", www.dow.com, 6/18/09 


\section{Gasoline Fuels}

E.37. Higher Carbon Alcohols--Properties

Higher carbon alcohols have greater energy density, lower miscibility with water, and lower vapor pressure than lower carbon alcohols like ethanol and methanol. [a]
Recent developments by Atsumi, Hanai, Liao (2008) enabled biosynthesis of branched higher alcohols (in table below) which are not natural fermenation products. [b] 2-methyl-1butanol and 3-methyl-1-butanol may be superior fuels to both ethanol and n-butane alcol

a) Kreame, N., Gross, C., Univeristy of Minnesota Biofuels Database, Branched Chain Alcohol Pathway, https://www.biofuelsdatabase.org/wikilindex.php5/Branched-Chain_Alcohol_Pathway

Molecular Formula

$(\mathrm{g} / \mathrm{mol})$

Elemental Composition (mass\%)

Hydrogen

Oxygen
Density $(\mathrm{g} / \mathrm{cm} 3)$

Vapor Pressure $(\mathrm{kPa})$

Boiling Point (degC)
Flash Point (degC)

Pour Point (degC)

Cloud Point

Freezing Point (degC)

High Heating Value $(\mathrm{MJ} / \mathrm{L})$
Low Heating Value $(\mathrm{MJ} / \mathrm{L})$

Water Solubility

Water in fuel (grams per $100 \mathrm{ml}$ water)

Fuel Miscibility
Solvation Potential

Flammability Limits (Vol\%)

Lower
Higher

Acid Number

Viscosity (mPa-s) at 20 degc
Vistater

Lubricity (um)

Acutety Rat oral LD50 (mg/kg)

Acute: Rat oral LD50 (mg/kg)

Acute: Rabbit eye irritation $(\mathrm{mg})$
Acute: Rabbit dermal $L D 50(\mathrm{~mL} / \mathrm{kg})$
Acute:Lethal for fish 82 -hour values (ppm)

Acute:Half max effective concentration for aquatic invertebrate (daphnia) (mg/L)

Properties

Acute: Aquatic plants - Half max effective concentration ( $\mathrm{mg} / \mathrm{L}$ )
Chronic: Rat inhalation Lowest observable effect conc

Chronic: Rat inhalation Lowest observable effect conc. (ppm)
Teratogenicity: Rat inhalataion No observable effect conc. (ppm)

Partition coefficient (Kow)

Log Kow at 25 degC

Bioconcentration factor $(\mathrm{L} / \mathrm{kg})$
Transport between Environmental Compartments

Soil/Air

Air/Water

Half-life in water at typical env. condition

Photodegradation half-life in air

Biodegradation

Appearance

Odor Threshold (ppm)

$\frac{\text { 2-methyl-1-butano }}{\text { C5H12O }}$

88.15

$\frac{\text { 3-methyl-1-butanol }}{\text { C5H12O }}$

Gasoline
C4 to C12
$100-105$

13.72

68.13
0.15
0.815

0.815
0.4
130
43

-70
$30.75[a]$

13.72

68.13
18.15
0.8

0.32

43

$$
\begin{gathered}
85-88 \\
12-15 \\
0-4
\end{gathered}
$$

$0.69-0.79$ at $15 \operatorname{deg} C$

$.69-0.79$ at 15 deg $C$
$48-103$ at 38 deg $C$
$27-225$

$27-225$
-43

-117
30.18 [a]

-40
35
$30-33$

3.

$$
2
$$

Negligible

1.1
9.3

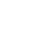

$\stackrel{1.2}{9}$

\subsection{6}

5.1

4.37

$88-100$
$0.37-0.44$

1300

20
3.97
100

$101200[a]$

3.54

references:
2-methyl-1-butanol

references:
3-methyl-1-butanol

\begin{tabular}{|c|c|c|}
\hline \multicolumn{2}{|r|}{ Not expected to bioconcentrate } & $\begin{array}{c}9000 \text { [a] } \\
\text { octanol-water } \\
2.13 \text { to } 4.85 \text { [a] }\end{array}$ \\
\hline \multicolumn{3}{|c|}{$\begin{array}{l}\text { Leaches into groundwater } \\
\text { Volatilizizes }\end{array}$} \\
\hline $\begin{array}{l}\text { Clear, colorless, liquid } \\
\text { Stench }\end{array}$ & $\begin{array}{l}\text { Rapid } \\
\text { Readily biodegrades } \\
\text { Clear, colorless, liquid } \\
\text { Disagreeable }\end{array}$ & $\begin{array}{l}0.8 \text { to } 16 \text { days [a] } \\
\text { Readily in aerobic cond. [a] } \\
\text { clear to amber [a] }\end{array}$ \\
\hline $137-32-6$ & 123-51-3 & \\
\hline
\end{tabular}

references:
gasoline

Fisher Scientific MSDS, DL-2-Methyl-1Butanol, 98\%, 11/20/2008, https://fscimage.fishersci.com/msds/52450.htm

a) Chao, Rossini, Heats of Combustion, Formation, and Isomerization of Nineteen Alkanols, Journal of Chemical Engineering Data, 1965, Vol. 10, pp. 374-379.

Fisher Scientific MSDS, 3-Methyl-1Butanol, 9/30/2002, https://fscimage.fishersci.com/msds/00798.htm
a) Chao, Rossini, Heats of Combustion, Formation, and I Isomerization of Nineteen Alkanols, Journal of Chemical Engineering Data, 1965, Vol. 10, pp. 374-379,

Alternative Fuels Guidebook: Properties, Storage, Dispensing, and Vehicle Facility Modifications

a) JT Baker MSDS, Gasoline, 10/14/2008, http:///mww.docs.citgo.com/msds_pil/UNLEAD.pdf 


\section{Gasoline Fuels}

E.38. Higher Carbon Alcohols--Compatibility and Environmental Issues

\section{Advantages \\ Low freezing point}

\section{Disadvantages}

Moderate flammability

Moderate toxicity

High oxygen content

Low vapor pressure

Somewhat soluble in water

references:
Fisher Scientific MSDS, DL-2-Methyl-1Butanol, 98\%, 11/20/2008, https://fscimage.fishersci.com/msds/52450.htm Fisher Scientific MSDS, 3-Methyl-1Butanol, 9/30/2002, https://fscimage.fishersci.com/msds/00798.htm 


\section{Biocrude and Intermediates}

E.39. Pyrolysis Oil--Properties

\begin{tabular}{|c|c|c|c|c|c|c|c|}
\hline Properties & NREL Oil * & Ensyn Oil** & $\underline{\text { MFR Specifications }{ }^{*+*}}$ & $\frac{\text { Fast Pyrolysis }}{\underline{\text { Bio-oil }}}$ & $\begin{array}{l}\text { Hydrothermal } \\
\text { Bio-oil }\end{array}$ & $\begin{array}{l}\text { Heavy Petroleum } \\
\text { Euel }\end{array}$ & \\
\hline $\begin{array}{l}\text { Molecular Formula } \\
\text { Molecular Weight (g/mol) }\end{array}$ & 370 & 550 & & & & & \\
\hline Elemental Composition (mass\%) & & & & & & & \\
\hline $\begin{array}{l}\text { Carbon } \\
\text { Hydrogen }\end{array}$ & 58.25 & 57.95 & & $39.5-55.8$ & $72.6-74.8$ & 85.2 & \\
\hline $\begin{array}{l}\begin{array}{l}\text { yydrogen } \\
\text { Oxygen }\end{array} \\
\text { ons }\end{array}$ & $\begin{array}{c}7.4 \\
3383\end{array}$ & 7.23 & & $7.5-6.1$ & 8.0 & 11.1 & \\
\hline $\begin{array}{l}\text { Oxyen } \\
\text { Nitrogen }\end{array}$ & 32.83 & $\begin{array}{l}33.19 \\
164\end{array}$ & & $37.9-52.6$ & & & \\
\hline $\begin{array}{l}\text { Tulogent } \\
\text { Sulfur }\end{array}$ & 1.52 & $\begin{array}{l}1.64 \\
1.22\end{array}$ & & $\begin{array}{l}<0.1 \\
<0.05\end{array}$ & $\begin{array}{l}<0.1 \\
<0.05\end{array}$ & 0.3 & \\
\hline Density (g/cm3) & & & & 1.23 & $\begin{array}{c}<0.05 \\
1.1\end{array}$ & $\begin{array}{c}2.3 \\
0.94\end{array}$ & Lower sulfur content \\
\hline $\begin{array}{l}\text { Vapor Pressure kPa } \\
\text { Boiling Point (degC) }\end{array}$ & & & & & & & \\
\hline Flash Point (degC) & & 55 [a] & & & & & \\
\hline $\begin{array}{l}\text { Pour Point (degC) } \\
\text { Cloud Point (degC) }\end{array}$ & & -25 [a] & & & & & \\
\hline High Heating Value (MJ/kg) & & $17.6[\mathrm{a}]$ & $\min .18[a]$ & $16.5-17.5$ & & 40 & Lower energy conter \\
\hline $\begin{array}{l}\text { Low Heating Value (MJ//kg) } \\
\text { Water Content }(\text { mass } \%)\end{array}$ & $\begin{array}{c}17 \\
169\end{array}$ & $\begin{array}{l}16.3 \\
263\end{array}$ & $\begin{array}{l}\min .16[a] \\
\max 26[a]\end{array}$ & $15-25$ & $3-5$ & 01 & \\
\hline $\begin{array}{l}\text { Water Content (masso\%) } \\
\text { Water Solubility at } 21 \text { degc }\end{array}$ & & & & & & & \\
\hline $\begin{array}{l}\text { Water in fuel (ppm) } \\
\text { Fuel Miscibility }\end{array}$ & & & & & & & \\
\hline Solvation Potential & & & & & & & \\
\hline Flammability Limits (Vol\%) & & & & & & & \\
\hline $\begin{array}{l}\text { Lower } \\
\text { Higher }\end{array}$ & & & & & & & \\
\hline & & 2.5 & & & & & \\
\hline $\begin{array}{l}\text { Cetane Number } \\
\text { Viscosity (mPa-s) }\end{array}$ & & 59 [a] & & $10-150$ at 50 degC & $3000-17000$ at $60 \operatorname{deg} C$ & 180 at $50 \mathrm{deg} C$ & Lower viscosity \\
\hline
\end{tabular}

Lubricity (um)
$*$ National Renewable Energy Laboratory wood-derived flash pyrolysis oil produced by ablative vortex reactor

Coration wood-derived flash pyrolysis oil produced in a

* Manufacturer Specifications Set by Ensyn (US/Canada), Wartsila (Finland), and Birka (Sweden) in the 1990s

\section{Information below for various pyrolysis oils: not only NREL Oil}

Acuxicity Animal Aerosol Inhalation LD50 (mg/m3)

Acute: Rabbit Dermal No observable effect concentration (mg/kg)

Acute: Rabbit Eye Corneal Damage (mL)

Acute: Oral (mg/kg)

Chronic: Rat and Mouse oral $(\mathrm{mg} / \mathrm{m} 3)$

Mutagenicity

$3100[b]$
$2000[b]$
$0.1[b]$
$700[b]$

Partition coefficient (Kow)

Bioconcentration factor $(L / k g)$

Soil adsorption

Half-life in water at typical env. condition

$\begin{array}{lc}\text { Biodegradation: Aerobic in freshwater, } 28 \text { days } & 41 \%-50 \% \text { [d] } \\ \text { Appearance } & \text { Strong Smoky [c] }\end{array}$

Odor threshold (ppm)
Biomass pyrolysis products formed at higher temperature have greater toxicity (see blow) [c]

Mixed Phenolic Allyl Heterocyclic Polycyclic

$\frac{\text { Oxygeantes }}{400^{\circ} \mathrm{C}} \Rightarrow \frac{\text { Ethers }}{500^{\circ} \mathrm{C}} \Rightarrow \frac{\text { Pheadics }}{600^{\circ} \mathrm{C}} \Rightarrow \frac{\text { Ethers }}{700^{\circ} \mathrm{C}} \Rightarrow \frac{\text { Larger }}{800^{\circ} \mathrm{C}} \Rightarrow \frac{\frac{\text { PAH }}{900^{\circ} \mathrm{C}}}{\mathrm{P}}$

References:
NREL oil, Ensyn oil, and MFR specifications

Shihadeh, Hochgreb, Energy and Fuels, 2002, 16, $552-561$.
a) Oasmaa, Peacocke, Gust, Meier, MLLellan, Norms and Standards for Pyrolysis Liquids. End-User Requirements and Specifications, Energy and Fuels C, http:///mmw.combio-project.com/download/PDF/COMBIO_WP2_specification.pd c) Ringer, Putsche, Scahill, Large-Scale Pyrolysis Oil Production: A Technology Assessment and Economic Analysis, National Renewable Energy Laboratory, NREL/TP-510-37779, November 2006. d) Blin, Volle, Girard, Bridgwater, Meier, Biodegradability of biomass pyrolysis oils: Comparison to conventional petroleum fuels and alternatives fuels in current use, 2007, Fuel, 86, 2679-2686

References: 


\section{Biocrude and Intermediates}

E.40. Pyrolysis Oil--Compatibility and Environmental Issues

Incompatible Materials

elastomers

$$
\begin{aligned}
& \text { metals } \\
& \text { aluminum } \\
& \text { mild steel } \\
& \text { nickel } \\
& \text { impure copper }
\end{aligned}
$$

Compatible Materials

elastomers

polyethylene

metals

polypropylene cobalt

polyester resins brass

\section{Advantages}

Biodegrades quickly

Less toxic than petroleum fuels

\section{Disadvantages}

corrosive

high viscosity

instability

temperature sensitivity

high char and solids content

contains alkali metals, leading to deposits in filters, boilers, engines, etc.

suspended char particles can contribute to phase separation

\section{Environmental/Health Concerns}

Biodegrades quickly

Less toxic than petroleum fuels

\section{Compatibility/Fungibility Issues}

Generally not soluble in water

Can phase separate

High oxygen content leads to polarity, can cling to pipe/vessel walls

references:

Hydroprocessing of Pyrolysis Bio-oil to Fuels and Chemicals, Bioenergy \& Wood Products, Smallwood, May 14, 2008, http://www.forestprod.org/smallwood08powerpoints.html

Qiang, Lu, Wen-Zhi, Li, Xi-Feng, Zhu, Overview of Fuel Properties of Biomass Fast Pyrolysis Oils, Journal of Energy Conversion and Management vol 50, 2009

Cirad-Foret, "MSDS: Bio-Oil", 5/06 


\section{Biocrude and Intermediates}

\section{E.41. Syngas--Properties}

\section{Properties}

Molecular Formula

Molecular Weight $(\mathrm{g} / \mathrm{mol})$

Gas Composition

Hydrogen Molecule

Carbon Dioxide

Nitrogen Molecule

Methane

Gaseous Compounds with more than two Carbon Atoms

Density (g/cm3)

Vapor Pressure $\mathrm{kPa}$ at $38 \mathrm{deg}$

Boiling Point

Wobbe Index (BTU/sc)

High Heating Value $\left(\mathrm{MJ} / \mathrm{m}^{\wedge} 3\right)$

Low Heating Value $\left(\mathrm{MJ} / \mathrm{m}^{\wedge} 3\right)$

Water Solubility at 21 degC

Water in fuel (\%mass)

Water content in fuel $\left(\mathrm{mg} / \mathrm{m}^{\wedge} 3\right)$

Fuel Miscibility

Flammability Limits (Vol\%)

Lower
Higher

Acid Number

Cetane Number

Viscosity (mPa-s)

\section{Toxicity based on Carbon Monoxide Content [b]}

Table of the effects of carbon monoxide on health and life

\begin{tabular}{|l|l|}
\multicolumn{2}{c|}{ Table of the effects of carbon monoxide on health and life } \\
\hline Concentration in ppm & Consequences \\
\hline 50 & Limit of tolerance for long exposure \\
50 to 100 & After some days, chronic poisoning \\
200 & Subacute poisoning \\
$1000-1500$ & Headache, nausea, poisoning and fatal in case of prolonged \\
2500 & exposure (more than 30 minutes) \\
3760 & Rapid collapse, death in one or two hours \\
5000 & LC50, one hour exposure \\
10000 & Massive poisoning, death in less than one hour \\
50000 & Death in 10 to 15 minutes \\
\hline
\end{tabular}

(50000

Odor threshold ( $\mathrm{mg} / \mathrm{m} 3)$

Odor threshold (ppm)

*Future Energy Resources Company (FERCO), 950 E. Paces Ferry Road, NE, Suite 810, Atlanta, GA 30326

\section{References:}

FERCO Bio-syngas

References:

Natural Gas

References:

Coal-derived Syngas and Landfill Gas

\begin{tabular}{|c|c|c|c|}
\hline$\frac{\text { FERCO* }}{\text { Bio-Syngas }}$ & $\frac{\text { Coal-derived }}{\text { Syngas }}$ & $\frac{\text { Landfill }}{\text { Gas }}$ & $\begin{array}{l}\text { Typical } \\
\text { Natural Gas }\end{array}$ \\
\hline 26.2 & 45 & & Trace \\
\hline 38.2 & 49 & & \\
\hline 15.1 & 2.9 & 37.5 & 0.7 \\
\hline 2 & 2.2 & 7 & 1.3 \\
\hline 14.9 & 0.9 & & 95.2 \\
\hline 4 & & & $\begin{array}{l}3.6 \\
0.58\end{array}$ \\
\hline \multirow[t]{2}{*}{$\begin{array}{c}499[\mathrm{a}] \\
16.30\end{array}$} & 450 & 639 & $\begin{array}{c}1367[\mathrm{a}] \\
37.8\end{array}$ \\
\hline & & & 16 to 32 \\
\hline & & & 4 to 16 \\
\hline
\end{tabular}

$75[b]$
Richard L. Bain, An Introduction to Biomass Thermochemical Conversion, DOE/NASLUGC Biomass and Solar Energy Workshops, August 3-4, 2004.

a) Paisley, Farris, Black, Irving, Overend, Preliminary Operating Results from the Battelle/FERCO Gasification Demonstration Plant in Burlington, Vermont, U.S.A. http://www.silvagas.com/downloads/seville.pdf

b) European Industrial Gases Association, Carbon Monoxide and Syngas Pipeline Systems, IGC Doc 120/04/E,

Union Gas Limited, Chemical Composition of Natural Gas, http://mww.uniongas.com/aboutus/aboutng/composition.asp, February 2010. a) Fergason, Straub, Richards, Robey, IImpact of Fuel Variability on Dynamic Instabilities in Gas Turbine Combustion, 5th US Combustion Meeting,
Organized by the Western States Section of the Combustion Institute and Hosted by the University of San Diego, March 25-28, 2007.

Ferguson, Straub, Richards, Robey, Impact of Fuel Variability on Dynamic Instabilities in Gas Turbine Combustion, 5th US Combustion Meeting. Organized by the Western States Section of the Combustion Institute and Hosted by the University of San Diego, March 25-28, 2007. 
Biocrude and Intermediates

E.42. Syngas--Compatibility and Environmental Issues

\section{Incompatible Materials}

elastomers metals

Buna N some grades of carbon steel

Neoprene low-alloy steel

Natural rubber high strength steel

Butyl rubber stainless steel

nickel alloy

\section{Compatible Materials}

elastomers metals

Viton low strength, high toughness carbon steel

Teflon microalloyed steel

\section{Environmental/Health Concerns}

Flammable

CO component is highly toxic

\section{Transportation Precautions}

Pipeline must be free of water to prevent serious corrosion when syngas is introduced

$\mathrm{H} 2$ component highly prone to leaks

references: $\quad$ European Industrial Gases Association, Carbon Monoxide and Syngas Pipeline Systems, www.eiga.org, 2004 


\section{Biocrude and Intermediates}

E.43. Lignin Liquids--Properties

\section{Properties}

Molecular Formula

olecular Weight $(\mathrm{g} / \mathrm{mol})$

\% $\%$ per dry solids for liquor)

Carbon

Oxygen

Nitrogen

Potassium
Sulfur

Chlorine

Lignin Concentration (\% mass per mass dry solids)

Density $(\mathrm{g} / \mathrm{cm} 3)$ at 26 - 30 degC for liquors

Vapor Pressure kPa at 38 degC

Boiling Point
Flash Point (degC)

Pour Point (degC)

Cloud Point (degC)

High Heating Value (MJ/L)

Water Solubility at 21 degC

Water in fuel (\%mass)

Water content in fuel (mg/kg)

Fuel Miscibility
Solvation Potential

Flammability Limits (Vol\%)

Lower

Acid Number

Cetane Number
Viscosity (mPa-s)

Kinematic viscosity $\left(\mathrm{mm}^{\wedge} 2 / \mathrm{s}\right)$

Toxicity Acute: Animal Aerosol Inhalation LD50 (mg/m3)

Wervable effect concentration $(\mathrm{mg} / \mathrm{kg})$

Acute:Fish LC50 and bacteria EC50 (mg/L)

Chronic: Rat and Mouse oral (mg/m3)

og Kow at 25 degc

Bioconcentration factor $(L / \mathrm{kg})[\mathrm{j}]$

Half-life in water at typical env. condition

Hall-life in atmosphere
Biodegradation: Aerobic in freshwater, 28 days

Appearance
Odor

Odor threshold $(\mathrm{mg} / \mathrm{m} 3)$

Odor threshold (ppm)

* The liquor viscosity de

Black Liquor References

FAME Specification Reference

Diesel References

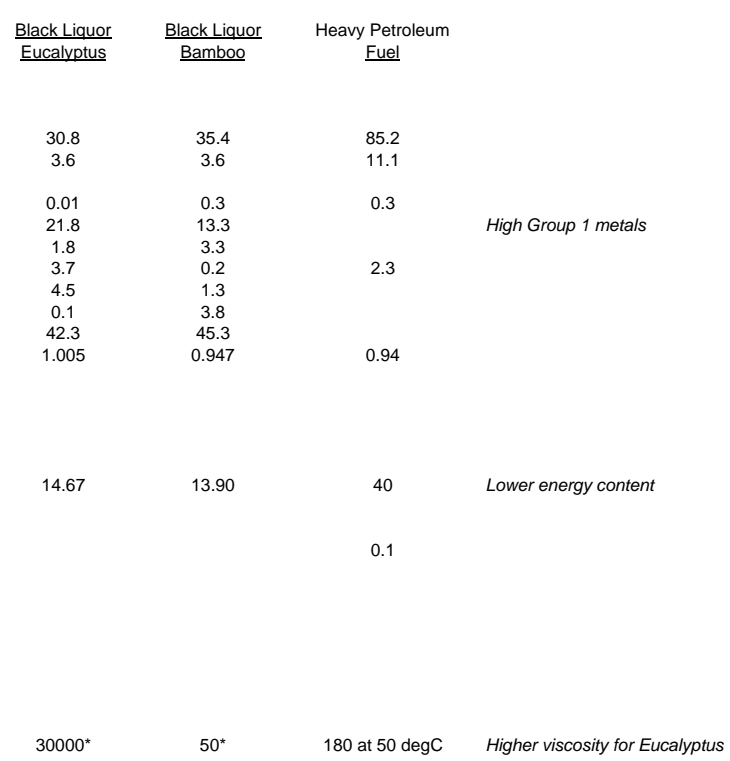

Cardoso, Domingos, Oliveira, Passos, Chemical Composition and Physical Properties of Black Liquors
and Their Effects on Liquor Recovery Operation in Brazilian Pulp Mills, Fuel, 2009, 88, 756 -763.

Hannu Jaaskelainen, Biodiesel Fuel Standards, http:///www.dieselnet.com/tech/fuel_biodiesel_std.html

Alternative Fuels Guidebook: Properties, Storage, Dispensing, and Vehicle Facility Modifications SAE Order Number R-180, 1997

hard L. Bechtold

a) Emissions and Lubricity Evaluation of Rapeseed Derived Biodiesel Fuels

SWRI 7507, November
Christopher A. Sharp

b) Hess, Boehman, Tijm, Waller, Experimental Studies of the Impact of CETANER on Diesel Combustion and Emissions, SAE Technical Paper 2000-01-2886 


\section{Biocrude and Intermediates}

E.44. Lignin Liquids--Compatibility and Environmental Issues

\section{Advantages}

Can be refined into a number of different fuels including DME, ethanol, methanol, FT diesel, and biogas

High land-use efficiency when processed to produce DME or methano

Disadvantages

Low diesel yield compared to DME/methanolletc. yields

Black liquor generation also produces highly corrosive $\mathrm{Na} 2 \mathrm{CO} 2$ and $\mathrm{Na} 2 \mathrm{~S}$ smelts that can damage a recovery boiler

references:

LeBlanc, Richard J., "Black Liquor Gasification Can Help Sustain Forests, Generate Ulitra-Clean Biofuels", Biomass Magazine, 7/09

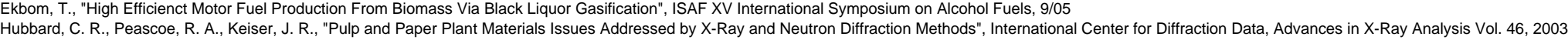
European Project BioDME, "Production of DME from Biomass and Utilisation as Fuel for Transport and for Industrial Use", 7 th Framework Program, 2009 


\section{Biocrude and Intermediates}

E.45. Sugar and Alcohols--Properties

\section{NO PUBLISHED DATA WAS FOUND FOR PROPERTIES OR CHEMISTRY OF MIXED SUGAR AND CARBOHYDRATE FEEDSTOCKS FOR FUEL PRODUCTION} ALCOHOL BASED FEEDSTOCKS WOULD BE EXPECTED TO HAVE SIMILAR PROPERTIES AND CHEMISTRY TO ALCOHOLS LISTED IN THE FUELS SECTIONS

\section{Fungible Fuels Composed of Gasoline- and Diesel-like Hydrocarbons Produced from Sugar and Alcohols}

Process developed by group of J. A. Dumesic at the University of Wisconsin-Madison:

\begin{tabular}{|c|c|c|c|c|c|c|}
\hline \multirow{3}{*}{ Biomass-derived carbohydrates } & & C4-C6 hydrocarbons & & & & \\
\hline & Carbon supported & \multirow{2}{*}{$\begin{array}{l}\text { Alcohols } \\
\text { Ketones } \\
\text { Carboxylic acids }\end{array}$} & C-C coupling & \multirow{2}{*}{ C7-C12 ketones } & Deoxygenation over & \multirow{2}{*}{ Diesel grade alkanes } \\
\hline & Pt-Re catalyst & & Processes & & $\mathrm{Pt} / \mathrm{NbOPO} 4$ catalyst & \\
\hline
\end{tabular}

References:

Gurbuz, Kunkes, Simonetti, West, Serrano-Ruiz, Gaertner, Dumesic (2009) Catalytic Production and Upgrading of Biomass Derived Monofunctional Hydrocarbons, Proceedings of the American Institute of Chemical Engineers Annual Meeting, November 2009, Nashville, TN.

Kunkes, Simonetti, West, Serrano-Ruiz, Gartner, Dumesic (2008) Catalytic Conversion of Biomass to Monofunctional Hydrocarbons and Targeted Liquid-fuel Classes, Science, Vol. 322, pp. 417-421.

Process developed by Virent Energy Systems, Inc., Madison, Wisconsin.

\begin{tabular}{|c|c|c|c|c|c|}
\hline & Hydrogenation & $\begin{array}{l}\text { Aqueous Phase } \\
\text { Reforming }\end{array}$ & Dehydration & Dehydration & Gasoline grade hydrocarbons \\
\hline $\begin{array}{r}\text { Sucrose } \\
\text { Xylose } \\
\text { Hydrogen }\end{array}$ & $\begin{array}{l}\text { Ru/Carbon } \\
\text { catalyst }\end{array}$ & $\begin{array}{l}\mathrm{Pt}+\mathrm{Re} / \text { Carbon } \\
\text { catalyst }\end{array}$ & $\begin{array}{l}\text { Tungstated } \\
\text { Zirconia } \\
\text { catalyst }\end{array}$ & $\begin{array}{l}\text { ZSM-5 } \\
\text { catalyst }\end{array}$ & \\
\hline
\end{tabular}

Aromatics (vol \%)

Sulfur

Density $(\mathrm{g} / \mathrm{cm} 3)$

Freezing Point (deg C)

Boiling Point

Flash Point (degC)

Specific Energy (MJ/kg)

Viscosity at $-20 \mathrm{C}(\mathrm{cSt})$

\section{Virent sugar-derived aviation fuel}

$\begin{array}{cc} & \text { Limit } \\ 1.1 & 25 \mathrm{max} \\ <0.001 & 0.3 \mathrm{max} \\ .775-.84 & 0.7398 \\ <-70 & -40 \mathrm{max} \\ 240.7 & 300 \mathrm{max} \\ 33 & 38 \min \\ 44.21 & 42.8 \\ 2.74 & 8 \max \end{array}$




\section{Biocrude and Intermediates}

E.46. Sugar and Alcohols--Compatibility and Environmental Issues

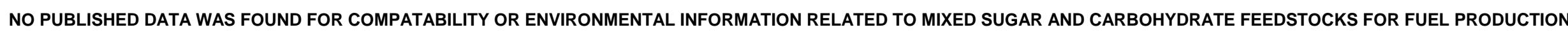

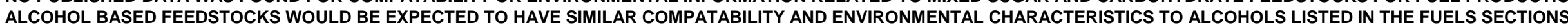

\section{Fungible Fuels Composed of Gasoline- and Diesel-like Hydrocarbons Produced from Sugar and Alcohols}

Process developed by group of J. A. Dumesic at the University of Wisconsin-Madison:
Monosaccharides
Sugar Alcohols

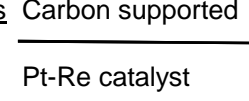
Carboxylic acids Processes
$\mathrm{Pt} / \mathrm{NbOPO} 4$ catalyst

Alcohols

C-C coupling

Deoxygenation over

References:

Gurbuz, Kunkes, Simonetti, West, Serrano-Ruiz, Gaertner, Dumesic (2009) Catalytic Production and Upgrading of Biomass Derived Monofunctional Hydrocarbons,

Proceedings of the American Institute of Chemical Engineers Annual Meeting, November 2009, Nashville, TN.

Kunkes, Simonetti, West, Serrano-Ruiz, Gartner, Dumesic (2008) Catalytic Conversion of Biomass to Monofunctional Hydrocarbons and Targeted Liquid-fuel Classes, Science, Vol. 322, pp. 417-421.

Process developed by Virent Energy Systems, Inc., Madison, Wisconsin. Aqueous Phase

\begin{tabular}{|c|c|c|c|c|c|}
\hline & Hydrogenation & $\begin{array}{l}\text { Aqueous Phase } \\
\text { Reforming }\end{array}$ & Dehydration & Dehydration & Gasoline grade hydrocarbons \\
\hline $\begin{array}{r}\text { Sucrose } \\
\text { Xylose } \\
\text { Hydrogen }\end{array}$ & $\begin{array}{l}\text { Ru/Carbon } \\
\text { catalyst }\end{array}$ & $\begin{array}{l}\mathrm{Pt+Re} / \text { Carbon } \\
\text { catalyst }\end{array}$ & $\begin{array}{l}\text { Tungstated } \\
\text { Zirconia } \\
\text { catalyst }\end{array}$ & $\begin{array}{l}\mathrm{ZSM}-5 \\
\text { catalyst }\end{array}$ & \\
\hline
\end{tabular}

Virent sugar-derived aviation fue

$\begin{array}{lcc} & 1.1 & 25 \max \\ \text { Aromatics (vol \%) } & <0.001 & 0.3 \max \\ \text { Sulfur } & .775-.84 & 0.7398 \\ \text { Density (g/cm3) } & <-70 & -40 \max \\ \text { Freezing Point (deg C) } & 240.7 & 300 \mathrm{max} \\ \text { Boiling Point } & 33 & 38 \mathrm{~min} \\ \text { Flash Point (degC) } & 44.21 & 42.8 \\ \text { Specific Energy (MJ/kg) } & 2.74 & 8 \mathrm{max} \\ \text { Viscosity at -20C (cSt) } & & \end{array}$

Viscosity at $-20 \mathrm{C}(\mathrm{cSt})$

Reference:

Blommel, Cortright of Virent Energy Systems, Inc., Production of Conventional Liquid Fuels from Sugars, White Paper, August 25, 2008.

Process developed by Aguayo et al. (2002) at the Universidad del Pais Vasco, Spain

\begin{tabular}{ll} 
& Isothermal fixed-bed reactor \\
\cline { 3 - 3 } Aqueous Ethanol & HZSM-5 zeolite catalyst
\end{tabular} Gasoline grade hydrocarbons

Reference:

Aguayo, Gayubo, Tarrio, Atutxa, Bilbao (2002) Study of Operating Variables in the Transformation of Aqueous Ethanol into Hydrocarbons on a HZSM-5 Zeolite,

Journal of Chemical Technology and Biotechnology, Vol. 77, pp. 211-216. 
Biocrude and Intermediates

E.47. Terpenes--Properties

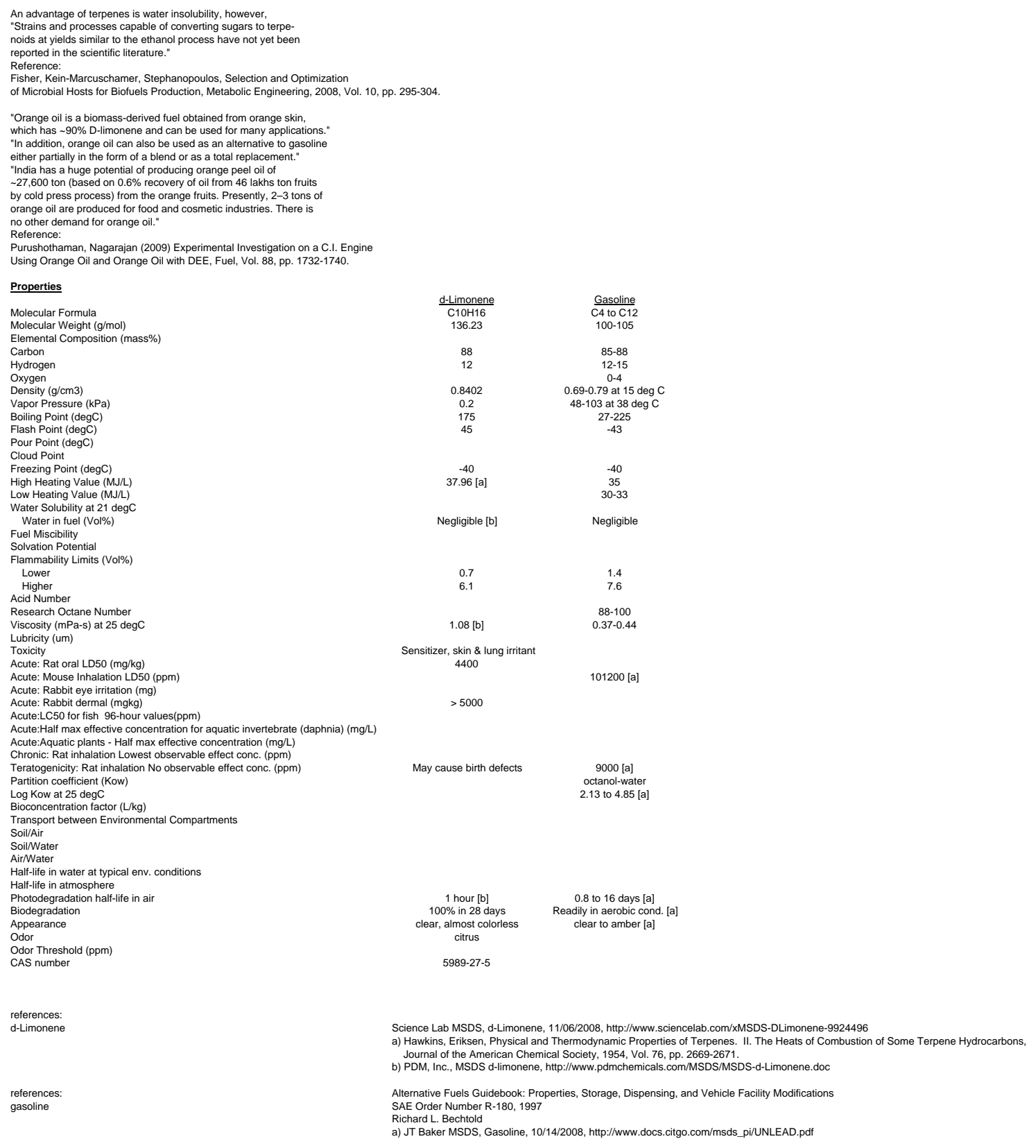


Biocrude and Intermediates

E.48. Terpenes--Compatibility and Environmental Issues

$\begin{aligned} & \text { Incompatible Materials } \\ & \text { elastomers }\end{aligned}$
$\begin{aligned} & \text { PVC } \\ & \text { nitrile }\end{aligned}$
$\begin{aligned} & \text { milicone } \\ & \text { Tygon }\end{aligned}$
$\begin{aligned} & \text { ferrous metals*al } \\ & \text { latex rubber } \\ & \text { neoprene }\end{aligned}$
$\begin{aligned} & \text { Compatible Materials } \\ & \text { elastomers }\end{aligned}$
$\begin{aligned} & \text { Teflon } \\ & \text { polypropylene } \\ & \text { epoxy }\end{aligned}$
$\begin{aligned} & \text { Viton } \\ & \text { nylon }\end{aligned}$
metals

\section{Vehicle Compatibility}

Compatible with terne-coated steel, commonly used for fuel tanks

Hoses made of nitrile or natural rubber must be replaced with Viton, etc.

\section{Advantages}

Negligibly miscible in water

\section{Disadvantages}

notes:

references: *non-corrosive to metals but can

become discolored by rust from ferrous metals

T2 Laboratories Inc., "Information Bulletin: Material Compatability with Terpene Chemicals", www.t2labs.com, 1995 
Biocrude and Intermediates

E.49. Isoprenes--Properties

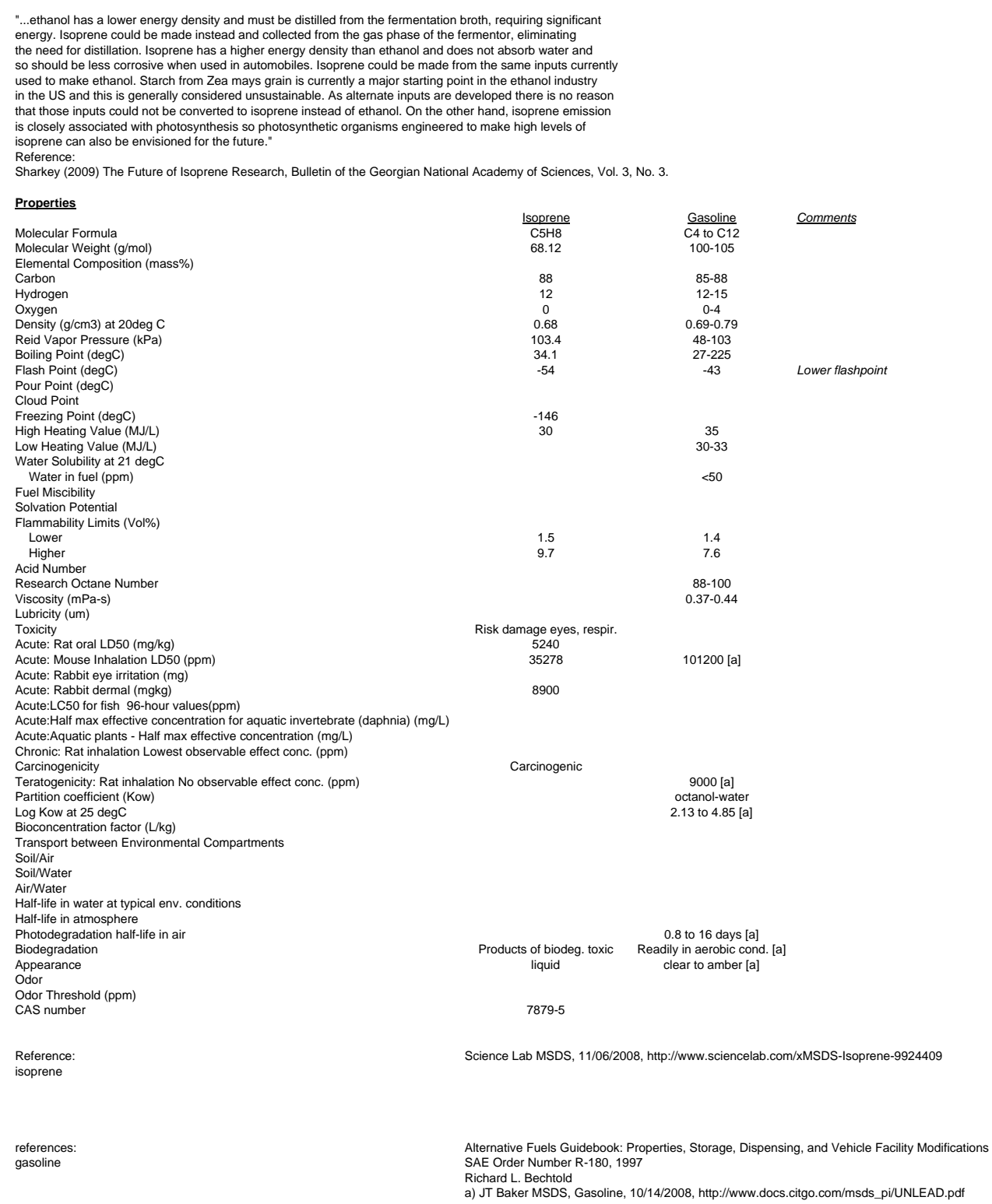


Biocrude and Intermediates

E.50. Isoprenes--Compatibility and Environmental Issues

Incompatible Materials

elastomers

$\underline{\text { metals }}$

\section{Compatible Materials}

elastomers

metals

\section{Advantages}

Water insoluble

\section{Disadvantages}

Highly flammable

Harmful to aquatic life in very low doses

Highly volatile

\section{Environmental/Health concerns}

Water insoluble

Flammable

Harmful to aquatic life in very low doses

\section{Compatibility/Fungibility issues}

Requires private track for transport by rail

\section{Production}

1996 US isoprene production capacity: 598 million lbs.

references:

Cameo Chemicals Inc., "Isoprene", www.cameochemicals.noaa.gov, 6/1999

ExxonMobil Chemical, "Isoprene Product Safety Summary", www.exxonmobilchemical.com, 6/2009

National Institute of Health, "Substance Profiles: Isoprene", www.ntp.niehs.nih.gov, 2000 


\section{Other}

\section{E.51. Methane--Properties}

"When fitted according to approved standards, the use of biomethane in vehicles can be safer than petrol.

This is due to the higher flammability limits, higher diffusion coefficient and auto-ignition temperature of biomethane (Cenex, 2009)."

Reference:

Renewable Energy, Landfill Gas and EfW: Now, Next and Future

K A Adu-Gyamfi, R Vilia and F Coulon

KA

\section{Motor vehicle fuel standard in Sweden for biomethane}

\begin{tabular}{|c|c|c|c|c|}
\hline Property & Units & $\begin{array}{l}\text { Requirement } \\
\text { Type A }\end{array}$ & $\begin{array}{l}\text { Requirement } \\
\text { Type B }\end{array}$ & Test Method \\
\hline Wobbe index morer $^{(1)}$ & $\mathrm{mJ} / \mathrm{m}^{2}$ & $41.7-46.4$ & $43.9-47.3$ & 55-150 6976 \\
\hline Methane (uolume at $273 \mathrm{~K}, 101.3 \mathrm{kPa}$ ) & $\%$ & $97 \pm 1$ & $97 \pm 2$ & 150 6974 \\
\hline Motor Octane Number (MON) & & 130 & 130 & 2) \\
\hline $\begin{array}{l}\text { Dewpoint at highest storage pressure } \\
t \text { - lowest monthly daily average } \\
\text { temperature }\end{array}$ & ${ }^{n} \mathrm{C}$ & 1.5 & +.5 & 1506327 \\
\hline Water content & $\mathrm{mg} / \mathrm{m}^{3}$ & 32 & 32 & $\begin{array}{c}\text { SS-EN ISO 10101- } \\
1,-2,-3\end{array}$ \\
\hline $\mathrm{CO}_{2}+\mathrm{O}_{2}+\mathrm{N}_{2}$ by volume, $\max$ & $\%$ & 4,0 & 5,0 & ISO 6974 \\
\hline Of which $\mathrm{O}_{2}$, $\max$ & $\%$ & 1.0 & 1.0 & \\
\hline Total sulphur & $\mathrm{mg} / \mathrm{m}^{2}$ & 23 & 23 & $\begin{array}{l}\text { IS0 6326-1,-2,-4 } \\
\text { 55-[N ISO-3,-5 }\end{array}$ \\
\hline $\begin{array}{l}\text { Total nitrogen compounds } \\
\text { calculated as } \mathrm{NI}_{3}\end{array}$ & $\mathrm{mg} / \mathrm{m}^{3}$ & 20 & 20 & $1506974^{5}$ \\
\hline Alcohol & & 9 & ๑ & \\
\hline
\end{tabular}

Reference:

EPUK (2006) Blogas as a Road Transport Fuel, National Society for Clean Air and

ittp://mww.environmentalprotection.org.uk/assets/library/documents/biogas as transport fuel june06.pdf

\section{Motor vehicle fuel standard in Austria (BGBL 417/04) and Europe (DIN 51624) for biomethane}

$$
\text { APUR) and raw biogas }
$$

Tabie 1: Composition and properties of raw biogas produced in Margarethen/Mocs

compared to methaPUR and CNG-quality defined by Austrian Law and DIN

\begin{tabular}{|c|c|c|c|c|c|}
\hline Component & $\begin{array}{c}\text { Raw } \\
\text { Biogas }\end{array}$ & $\begin{array}{c}\text { methaPUR } \\
\text { standard }\end{array}$ & $\begin{array}{l}\text { Austrian Law } \\
\text { BGBL } 417 / 04\end{array}$ & $\begin{array}{c}\text { DIN } \\
51624\end{array}$ & Unit \\
\hline Methane & $49 \pm 10$ & $>95$ & NR & $>80$ & $\mathrm{~mol} \%$ \\
\hline Carbon dioxide & $51 \pm$ & $<5$ & NR & & $\mathrm{mol} \%$ \\
\hline Nitrogen & $<0,3$ & $<1,0$ & $\mathrm{NR}$ & $\operatorname{um}<15$ & $\mathrm{~mol} \%$ \\
\hline Oxygen & $\infty .1$ & $<1.0$ & NR & $<3.0$ & $\mathrm{~mol} \%$ \\
\hline Hydrogen sulphide & $5(<20)$ & $<10$ & $\mathrm{NR}$ & $<5^{\circ}$ & ppmv \\
\hline Water & saturated & "dried" & NR & $<40$ & $\mathrm{mg} / \mathrm{kg}$ \\
\hline Particulate $\mathrm{n}$ & techn. free & techn free & techn. free & & $\mathrm{mg} / \mathrm{kg}$ \\
\hline Relative den & & $0,60^{+}$ & $0,55-0,7$ & $0,56-0,70^{*}$ & $\mathrm{kWh} / \mathrm{m}$ \\
\hline Upper Calorific value & $5,40^{\circ}$ & $>10,45$ & $8,4-13,1$ & NR & $\mathrm{kWh} / \mathrm{m}$ \\
\hline Wobbe Index & $5,27^{\circ}$ & $>13,6$ & $12,8-15,7$ & NR & $\mathrm{kWh} / \mathrm{m}$ \\
\hline
\end{tabular}

"In order to produce fuel for the Austrian market, the product has to fulfill the Austrian law Kratsstorverordnung" BGBL 417/04, while in Germany and many other European countries DIN 51624 is applicable. It is planned to merchandize upgraded biogas on has ben estalished, unitying the num; definition of the methaPUR standard is compared to the composition of gaseous fuels (CNG - compressed natural gas) prescribed in the aforementioned laws and to the raw biogas in Table 1. It has to be mentioned, that the hydrogen sulphide content of the raw biogas is extremely low due to effective in-situ-desulphurization using commercially available liquid mixtures of metal salts and due to the favorable local substrate mixture

It can be easily seen that in order to upgrade biogas to accepted fuel qualities, several

$$
\ldots \text { calculated }
$$

NR... not regilated

Reference:

ding for transportation purposes - Operational Experiences with Austria's first Bio-CNG fuelling station

in Miltner, Aleksander Makaruk, Harald Bala, Michael Harasek

http://mww.aidic.it/pres09/webpapers/134Miltner. pd

Chem Eng Trans, 2009 
Incompatibility

$\underline{\text { elastomers }}$

\section{Compatibility}

elastomers

$\underline{\text { metals }}$

\section{Advantages}

Non-toxic

Can produce significant reductions in $\mathrm{CO} 2, \mathrm{CO}, \mathrm{NOx}$, and PM emissions

\section{Disadvantages}

Must be compressed to a liquid for ease of transport

Highly flammable

Can produce significant increases in $\mathrm{HC}$ emissions (20x that of gasoline vehicles in Sweden) Can produce significant increases in fuel consumption versus comparable diesel engines

\section{Environmental/Health concerns}

Non-toxic

Flammable

\section{Compatibility/Fungibility issues}

Must be compressed to a liquid for ease of transport

Trucks carrying methane not permitted in tunnels

\section{Motor vehicle fuel standard in Sweden for biomethane}

Biogas produced to this standard is subject to a number of storage and handling requirements:

- It shall not include dirt, oil or other substances which can damage engine tuel systems;

- The potential for oil carry-over from gas compressors needs to be mitigated by the use of molecular vil filters downstream of the compressor;

- Alcohol may not be added to avoid freezing as this can cause corrosion in storage tanks;

- The gas shall be odorised to enable the detertion of gas at up to a concentration of $20 \%$ of its flammability limit. The odorising medium shall not be harmful to health. It may also increase the sulphur content in the fucl.

\section{Table 5.1: Summary of Costs for the Production of Biogas Used as a Vehicle Fuel}

\begin{tabular}{l|c|c|c|c} 
Process & \multicolumn{2}{|c|}{ Biogas (sewage sludge) } & \multicolumn{2}{c}{ Biogas (organic waste) } \\
\hline & $\mathbf{S E K} / \mathbf{N m}^{3}$ & $\mathbf{p} / \mathbf{N m}^{3}$ & $\mathbf{S E K} / \mathbf{N m}^{3}$ & $\mathbf{p} / \mathbf{N m}^{3}$ \\
\hline Production & $0-1.5$ & $0-11$ & $1.5-2.5$ & $11-18$ \\
\hline Upgrading & $1-2$ & $7-15$ & $1-2$ & $7-15$ \\
\hline Compression & 1 & 7 & 1 & 7 \\
\hline Total & $2.0-4.5$ & $14-33$ & $3.5-5.5$ & $25-40$
\end{tabular}


Properties

Properties

\section{Production of bio-hydrogen is in research phase}

"Researchers at The National Renewable Energy Laboratory (NREL) are developing advanced processes

to produce hydrogen economically from sustainable resources. These R\&D efforts include:

Fermentation

Biological Water Splitting

Photoelectrochemical Water Splitting

Conversion of Biomass and Wastes

Solar Thermal Water Splitting

Renewable Electrolysis."

Reference:

http://www.nrel.gov/hydrogen/proj_production_delivery.html\#water

"Currently most hydrogen is produced from fossil fuels (e.g. steam reforming of natural

gas). Prototype hydrogen vehicles have been developed, but there is currently no

significant infrastructure for distributing hydrogen as a transport fuel, and in-vehicle

storage capacity is still an issue. In addition, hydrogen fuel cells are expensive to produce and fragile, and have a relatively short service life."

"Extensive research is being carried out on chemical storage of hydrogen"

Reference:

European Biofuels Technology Platform, funded by the EC under Grant Agreement 241269,

Last updated February 23, 2010

http://www.biofuelstp.eu/hydrogen.html

\section{Chemical Hydrogen Storage R\&D}

"DOE's chemical hydrogen storage R\&D is focused on developing low-cost energy-

efficient regeneration systems for these irreversible hydrogen storage systems. Significan technical issues remain regarding the regeneration of the spent material and whether regeneration can be accomplished on-board. In addition, life cycle cost analysis is needed to assess the costs of regeneration. Currently, borohydride-water systems, magnesiumhydride slurries, and innovation beyond boron are under investigation."

"Research is carried out through DOE's Chemical Hydrogen Storage Center of Excellence and Independent Projects overseen by the Fuel Cell Technologies Program."

Reference:

DOE Fuel Cell Technologies Program

http://www1.eere.energy.gov/hydrogenandfuelcells/storage/hydro_storage.html

\section{Hydrogen Infrastructure}

"Germany to Launch Nationwide Hydrogen Fuel Network by 2015

Signs a memorandum of understanding with eight industrial partners,

including Daimler, Shell, and Total."

Reference:

http://www.nacsonline.com/NACS/News/Daily/Pages/ND0917097.aspx 
Other

E.54. Hydrogen--Compatibility and Environmental Issues

Incompatible Materials elastomers

Compatible Materials

\section{elastomers}

Advantages

Disadvantages

Highly flammable

Must be compressed to a liquid for ease of transport

\section{Environmental/Health concerns}

Flammable

\section{Compatibility/Fungibility issues}

Must be compressed to a liquid for ease of transport

Trucks carrying hydrogen not permitted in tunnels

notes:

*high strength steels (above $100 \mathrm{ksi}$ ) are more suscpetible to

hydrogen embrittlement, therefore low strength steels are

recommended for hydrogen pipelines

references:

BOC Gases, "MSDS: Hydrogen", www.fergusongases.com, 6/7/1996

Gillette and Kolpa, Argonne National Laboratories, "Overview of Interstate Hydrogen Pipeline Systems", www.corridoreis.anl.gov, 11/07 